WALASON DA SILVA ABJAUDE

ESTUDO DE LETALIDADE SINTÉTICA EM CÉLULAS TRANSFORMADAS POR PAPILOMAVÍRUS HUMANO (HPV)

Tese apresentada ao Programa de Pós-Graduação em Microbiologia do Instituto de Ciências Biomédicas da Universidade de São Paulo, para obtenção do Título de Doutor em Ciências. 
WALASON DA SILVA ABJAUDE

\section{ESTUDO DE LETALIDADE SINTÉTICA EM CÉLULAS TRANSFORMADAS POR PAPILOMAVÍRUS HUMANO (HPV)}

Tese apresentada ao Programa de Pós-Graduação em Microbiologia do Instituto de Ciências Biomédicas da Universidade de São Paulo, para obtenção do Título de Doutor em Ciências.

Área de Conhecimento: Microbiologia Orientador: Prof. Dr. Enrique Boccardo

Versão Original 
CATALOGAÇĀO NA PUBLICAÇĀO (CIP)

Serviço de Biblioteca e informaçāo Biomédica

do Instituto de Ciências Biomédicas da Universidade de Sāo Paulo

Ficha Catalográfica elaborada pelo(a) autor(a)

Abjaude, Walason

Estudo de letalidade sintética em células

transformadas por Papilomavírus Humano (HPV) /

Walason Abjaude; orientador Enrique Mario Boccardo

Pierulivo. -- São Paulo, 2016.

95 p.

Tese (Doutorado)) -- Universidade de são Paulo, Instituto de Ciências Biomédicas.

1. HPV. 2. Letalidade Sintética. 3. Oncologia. 4. Reparo de DNA. 5. Virologia. I. Boccardo Pierulivo, Enrique Mario, orientador. II. Título. 
Candidato(a): Walason da Silva Abjaude

Título da Tese: Estudo de letalidade sintética em células transformadas pelo papilomavírus humano (HPV).

Orientador(a): Enrique Mario Boccardo Pierulivo

A Comissão Julgadora dos trabalhos de Defesa da Tese de Doutorado, em sessão pública realizada a .$/$ considerou

( ) Aprovado(a) ( ) Reprovado(a)

\begin{tabular}{|c|c|}
\hline Examinador(a): & 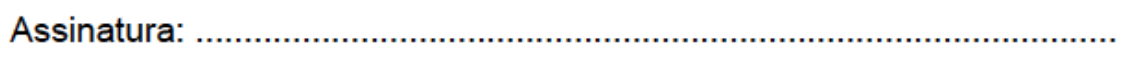 \\
\hline & Nome: $\ldots \ldots \ldots \ldots \ldots \ldots \ldots \ldots \ldots \ldots$ \\
\hline & Instituição: ............ \\
\hline Examinador(a): & Assinatura: ................. \\
\hline & Nome: ....................... \\
\hline & Instituição: ............................. \\
\hline Examinador(a): & Assinatura: .......................... \\
\hline & Nome: ...................... \\
\hline & Instituição: ..... \\
\hline Examinador(a): & Assinatura: .... \\
\hline & Nome: ....................... \\
\hline & Instituição: ................................ \\
\hline Presidente: & \\
\hline & lome \\
\hline & stituic \\
\hline
\end{tabular}




\section{CERTIFICADO DE ISENÇÃO}

Certificamos que o Protocolo CEP-ICB N $\mathrm{N}^{\circ} \mathbf{5 4 3 / 1 2}$ referente ao projeto intitulado: "Estudo de Letalidde Sintética em células infectadas por Papilomavirus Humano (HPV)" sob a responsabilidade de Walason da Silva Abjaude, foi analisado na presente data pela CEUA COMISSÃO DE ÉTICA NO USO DE ANIMAIS e pela CEPSH- COMISSÃO DE ÉTICA EM PESQUISA COM SERES HUMANOS, tendo sido deliberado que o referido projeto não utilizará animais que estejam sob a égide da lei 11.794 de 8 de outubro de 2008, nem envolverá procedimentos regulados pela Resolução CONEP nº196 de 1996.

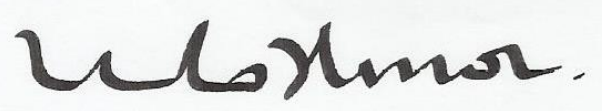

PROF. DR. Wothan TAVARES DE LIMA Coordenador da CEUA - ICB/USP
São Paulo, 23 de agosto de 2012.

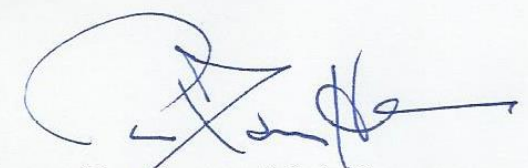

PRof. DR. PAOLO M.A ZanotTo Coordenador da CEPsh - ICB/USP 
Dedico este trabalho aos meus pais, João Bosco e Rosane, os quais sempre foram fonte de amor, dedicação e de inspiração. Obrigado por apoiarem os meus sonhos e serem a minha grande fortaleza nesta caminhada! 


\section{AGRADECIMENTO ESPECIAL}

A Universidade de São Paulo e aos órgãos de fomento: Fundação de Amparo à Pesquisa do Estado de São Paulo (FAPESP - Processos: 2010/20002-0, 2012/16512-8, 2014/21361-4), Conselho Nacional de Desenvolvimento Científico e Tecnológico (CNPq), Coordenação de Aperfeiçoamento de Pessoal de Nível Superior (CAPES) e Instituto Nacional de Ciência e Tecnologia das Doenças Associadas ao Papilomavírus (INCT-HPV - Processo: 573799/2008), sem os quais este estudo não seria realizado. 


\section{AGRADECIMENTOS}

Mais um ciclo que se encerra na minha vida profissional e neste momento faço a minha reflexão. Foi uma jornada de muitos obstáculos, porém que me trouxeram inúmeros aprendizados e vitórias. Hoje comemoro esta grande vitória, mas que sozinho não teria conseguido chegar tão longe. Muitos foram os protagonistas desta história e que agora tenho muito a agradecer.

Primeiramente aos meus pais, João Bosco e Rosane Abjaude, meus exemplos, pelas ligações diárias, que fizeram com que toda a nossa distância fosse um "logo ali" e que o "Uai!" não fosse esquecido. Todo amor, todo carinho e todos os cuidados recebidos me mantiveram firmes na busca dos meus sonhos.

Ao meu orientador, Enrique Boccardo, pela orientação, dedicação, paciência e, principalmente, pelos inúmeros questionamentos e desafios impostos, que me levaram a superar meus próprios limites e ao meu amadurecimento profissional.

Aos amigos do Laboratório de Oncovirologia: Aline, Bia, Bruna, Claúdia, Mirian, Suellen, Tatiana e Vanesca pelo companheirismo e amizade. Quando as coisas não saiam como o previsto, vocês sempre estavam presentes para que o choro fosse um motivo de risada.

Aos professores Carlos Frederico Martins Menck e Luisa Lina Villa, e a todos dos seus laboratórios pela grande ajuda no desenvolvimento deste projeto e pelas contribuições intelectuais.

A todos os professores, funcionários e colegas da pós-graduação por estarem presentes na minha vida todos os dias nesses últimos anos.

E por fim, porém não menos importante, a todos os amigos, que mesmo sem saberem o que era microbiologia e que achavavam que eu só estudava, foram a minha segunda família nesta cidade e fizeram meus dias tão especiais. 
"Thoughts without content are empty, intuitions without concepts are blind. The understanding can intuit nothing, the senses can think nothing. Only through their union can knowledge arise." 


\section{RESUMO}

Abjaude WS. Estudo de letalidade sintética em células transformadas por Papilomavírus Humano (HPV). [Tese (Doutorado em Microbiologia)] - Instituto de Ciências Biomédicas, Universidade de São Paulo, São Paulo; 2016.

Os Papilomavírus Humanos (HPV) são vírus de DNA, não envelopados que infectam as células epiteliais. A infecção persistente por alguns tipos de HPV é o principal fator de risco para o desenvolvimento do câncer cervical. A maquinaria de reparo de DNA desempenha um papel essencial em várias fases do ciclo de vida do HPV e é crucial para a sobrevivência de células tumorais. Durante a transformação maligna, as oncoproteínas E6 e E7 de HPV são capazes de induzir alterações cromossômicas e numéricas, além de modular a resposta de danos ao DNA. Estas observações sugerem que a maquinaria celular de reparo de dano ao DNA podem desempenhar um papel duplo na biologia do HPV e na sua patogênese. No presente estudo, procurou-se investigar o papel das proteínas de reparo de DNA na biologia das células derivadas de câncer cervical. A fim de alcançar este objetivo, a expressão de 189 genes foi silenciada em células HeLa (HPV 18) e em células $\mathrm{SiHa}$ (HPV16), bem como em queratinócitos humanos primários (QHP), utilizando vetores lentivirais que expressam shRNAs específicos. O efeito do silenciamento gênico foi determinado por ensaios de viabilidade celular, análise de proliferação celular, ensaio clonogênico e de formação de colônias em soft ágar. Observamos que o silenciamento dos genes ATM, BRCA1, CHEK2 e HMGB1 reduziu a taxa de crescimento celular, o potencial de crescimento em colônia e a capacidade de crescimento independente de ancoragem das linhagens celulares derivadas de câncer cervical transformadas por HPV, sem afetar QHP. O tratamento das linhagens celulares com fármacos capazes de inibir a atividade das proteínas ATM e CHEK2 revelou uma maior sensibilidade das células tumorais à inibição destas proteínas quando comparadas a QHP. Além disso, mostramos que QHP que expressavam E6E7 ou somente E6 de HPV16 foram mais sensíveis a estes inibidores, quando comparados ao controle QHP ou QHP expressando apenas E7. Além disso, QHP que expressavam mutantes de E6 de HPV16, defectivos para a degradação de p53, foram menos sensíveis do que QHP, que expressavam HPV16 E6 selvagem. Desta forma, estes resultados indicam que estes genes são necessários para a sobrevivência de células transformadas por HPV. Além disso, os nossos resultados sugerem que este efeito está relacionado com a expressão oncoproteína de HPV16 E6 e a sua capacidade para degradar p53

Palavras-chave: HPV. Letalidade Sintética. Reparo de DNA 


\begin{abstract}
Abjaude WS. Study of synthetic lethality in HPV-transformed cells. [thesis (Ph.D thesis in Microbiology)] - São Paulo: Instituto de Ciências Biomédicas, Universidade de São Paulo; 2016.

Human Papillomaviruses (HPV) are non-enveloped DNA viruses that infect epithelial cells. Persistent infection with some HPV types is the main risk factor for the development of cervical cancer. DNA repair machinery plays an essential role in several stages of the HPV life cycle and is crucial for tumor cells' survival. During malignant transformation, HPV E6 and E7 oncoproteins induce structural and numerical chromosome alterations and modulate DNA damage response. These observations suggest that cellular DNA repair machinery may play a dual role in both HPV biology and pathogenesis. In the present study, we sought to investigate the role of DNA repair proteins in cervical cancer derived cells biology. In order to achieve this goal, the expression of 189 genes was silenced in HeLa (HPV18) and $\mathrm{SiHa}$ (HPV16) cells as well as in primary human keratinocytes (PHK) using lentiviral vectors expressing specific shRNA. The effect of gene silencing was determined by cell viability assay, cell growth analysis, clonogenic and soft agar colony formation test. We observed that ATM, BRCA1, CHEK2 and HMGB1 down-regulation decreased growth rate, clonogenic potential and cellular anchorage-independent growth of HPV-transformed cervical cancer-derived cell lines with no effect in normal keratinocytes. Treatment of cells with drugs that inhibit ATM and CHEK2 activity showed that tumor cells are more sensitive to the inhibition of these proteins than PHK. Besides, we show that PHK expressing HPV16 E6 alone or along with HPV16 E7 were more sensitive to these inhibitors than control PHK or PHK expressing only E7. Moreover, PHK expressing E6 mutants defective for p53 degradation were less sensitive than PHK expressing E6wt. Moreover, to potentiate the effect observed by the ATM and CHEK2 inhibition, we treated cells lines with Doxorubicin and Cisplantin. We observed that tumor cells lines and PHK expressing HPV16 E6 or HPV16 E6/E7 were more sensitive to DNA damage induction. Altogether, these results indicated that these genes are required for HPV-transformed cells survival. Besides, our results suggest that this effect is related to HPV16 E6 oncoprotein expression and its capacity to degrade p53.
\end{abstract}

Keywords: DNA Repair. HPV. Synthetic Lethality. 


\section{LISTA DE FIGURAS}

Figura 1 - Organização do genoma de HPV e o ciclo de vida viral.........................20

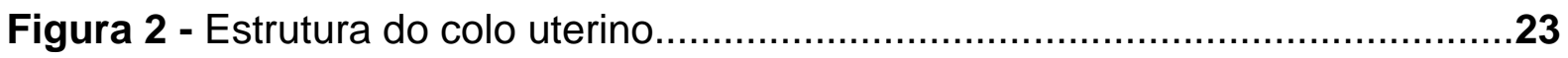

Figura 3 - Infecção do vírus HPV e o processo de carcinogênese...........................23

Figura 4 - Fonte de danos ao DNA e os mecanismos de reparo............................27

Figura 5 - Vias de sinalização em resposta ao dano ao DNA .................................28

Figura 6 - Replicação Viral e a Maquinaria de Reparo de Dano ao DNA..................31

Figura 7 - Silenciamento Gênico mediado por shRNA e siRNA ................................36

Figura 8 - Mapa esquemático do plasmídeo pLXSN.............................................

Figura 9 - Mapa esquemático do plasmídeo pLKO.1-puro que carrega as sequências de shRNA.

Figura 10 - Eletroforese em gel de agarose $0,8 \%$ dos produtos de extração dos vetores pLKO.1 puro com o inserto de shRNA dos diferentes clones da biblioteca de genes Supressores de Tumor e de Reparo ao Dano de DNA.

Figura 11 - Curva Padrão para Determinação da Concentração de p24

Figura 12 - Análise da viabilidade e proliferação de células HeLa e SiHa após silenciamento de diversos genes.

Figura 13 - Identificação dos clones de shRNA capazes de reduzir a viabilidade e a proliferação de HeLa e SiHa.

Figura 14: Validação da viabilidade e proliferação de células QHP, HeLa e SiHa com os 34 possíveis candidatos de shRNA.

Figura 15 - Determinação dos níveis das proteínas ATM, CHEK2 e HMGB1 por western blot após o silenciamento gênico

Figura 16 - Efeito do silenciamento dos genes ATM, CHEK2, BRCA1 e HMGB1 no potencial clonogênico de células HeLa e SiHa .57

Figura 17 - Efeito do silenciamento dos genes ATM, CHEK2, BRCA1 e HMGB1 no potencial de crescimento independente de ancoragem de células HeLa e $\mathrm{SiHa}$ .58

Figura 18 - Curva de Crescimento das células tumorais HeLa e SiHa e dos Queratinócitos Humanos Primários silenciadas para os genes ATM, CHEK2, BRCA1e HMGB1. .59 
Figura 19 - Efeito do silenciamento dos genes ATM, CHEK2, BRCA1 e HMGB1 na viabilidade de QHP transduzidos com as oncoproteínas virais E6 e/ou E7 de HPV16.

Figura 20 - Determinação da concentração inibitória 50\%. 63

Figura 21 - Efeito da inibição de ATM e CHEK2 por meio de fármacos nas linhagens celulares tumorais e em QHP normais. 64

Figura 22 - Efeito da inibição de ATM e CHEK2 por meio de fármacos nas linhagens de QHP normais e QHP expressando E6 e/ou E7 de HPV16, E6 mutante de HPV16 ou E6 de HPV16 silenciado para a ubiquitina-ligase E6AP. .65

Figura 23 - Efeito da inibição de ATM e de CHEK2 nas linhagens tumorais quando induzidas ao dano ao DNA por doxorrubicina e cisplatina. 68

Figura 24 - Efeito da inibição de ATM e de CHEK2 nas linhagens de QHP transduzidas com os vetores de E6 e/ou E7 de HPV16, quando induzidas ao dano ao DNA por doxorrubicina e/ou cisplatina .70

Figura 25 - Efeito da inibição de ATM e de CHEK2 nas linhagens de QHP transduzidas com os vetores de E6 de HPV16, E6 mutante de HPV16 e E6 de HPV16 silenciada para E6AP, quando induzidas ao dano ao DNA por doxorrubicina e/ou cisplatina. 71

Figura 26 - Determinação dos níveis de fosforilação do resíduo de serina 1981 da proteína ATM mediante o tratamento com inibidor de ATM ou doxorrubicina. .73 


\section{LISTA DE TABELAS}

Tabela 1 - Regiões do genoma de HPV com as suas respectivas funções.............19

Tabela 2 - Biblioteca dos vetores lentivirais referente aos 116 genes envolvidos nas vias de Reparo de dano ao DNA e aos 76 genes Supressores de Tumor

Tabela 3 - Lista de anticorpos utilizados e respectivas concentrações....................46

Tabela 4 - Concentração viral obtida a partir dos sobrenadantes lentivirais............50

Tabela 5 - Funções de HMGB1 e sua localização celular.....................................78 


\section{LISTA DE ABREVIATURA E SIGLAS}

ATM - Ataxia telangiectasia mutated

ATR - Ataxia telangiectasia and Rad3 related

BER - Base excision repair

BRCA1 - Breast Cancer 1

BRCA2 - Breast Cancer 2

CDK - Cyclin-dependent kinase

CHEK1 - Checkpoint kinase 1 homolog (S. cerevisiae)

CHEK2 - Checkpoint kinase 2 homolog (S. cerevisiae)

DDR - DNA damage response

DNA - Ácido desoxirribonucléico

DSB - Double strand break

GGR - Global genome repair

HMGB1 - High Mobility Group Box 1

HPV - Papilomavírus humano

MMR - Mismatch repair

NER - Nucleotide excision repair

NHEJ - Non-homologous end joining

ORF- Open reading frame (Janela aberta de leitura)

PCNA - Proliferating cell nuclear antigen

QPH - Queratinócitos primários humanos

RNA - Ácido ribonucléico

RNAi - RNA Interference

RNAm - Ácido ribonucléico mensageiro

shRNA - Small Hairpin RNA

SSB - Single strand break

TCR - Transcription coupled repair 


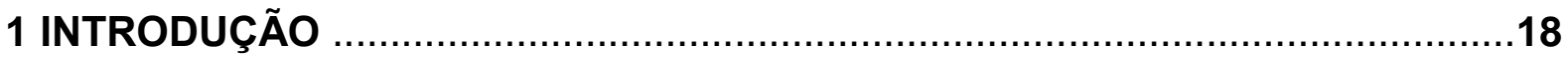

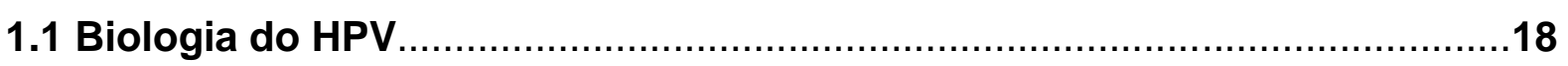

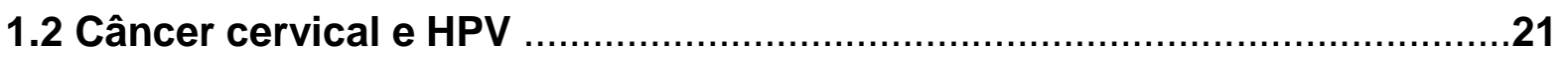

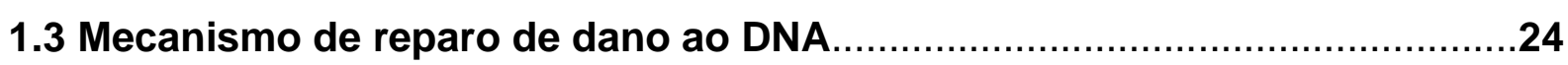

1.4 HPV e a maquinaria de reparo de DNA .............................................29

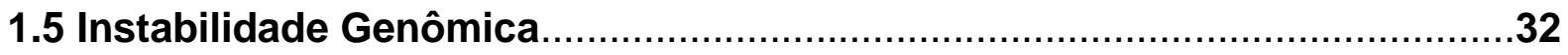

1.6 Silenciamento gênico e letalidade sintética........................................34

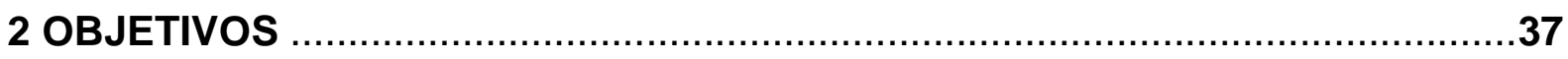

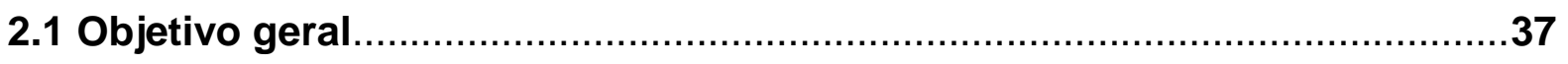

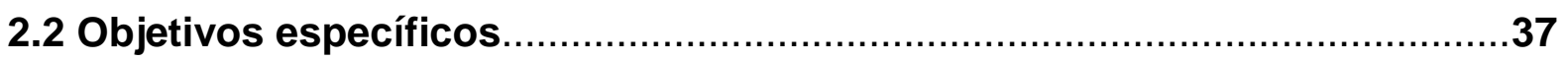

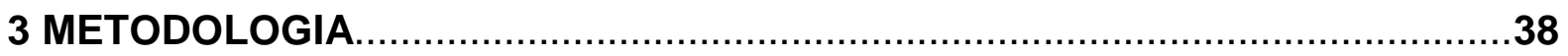

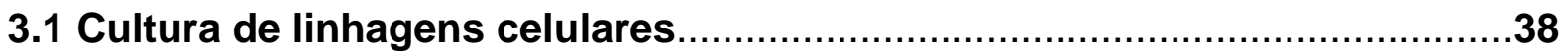

3.1.1 Queratinócitos e vetores retrovirais..................................................38

3.2 Bibliotecas de vetores lentivirais....................................................

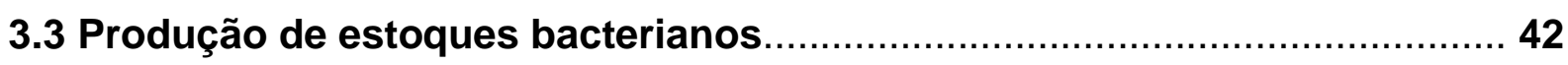

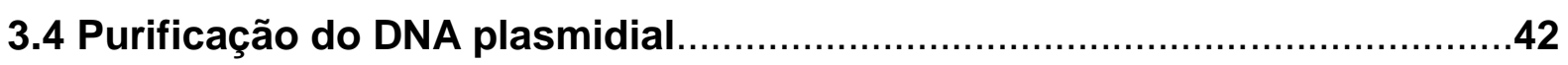

3.5 Obtenção de partículas lentivirais e titulação.......................................43

3.6 Transdução de linhagens celulares e viabilidade celular.........................43

3.6.1 Transdução das linhagens celulares para o silenciamento dos genes de

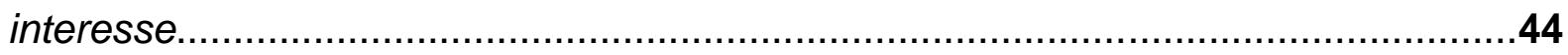

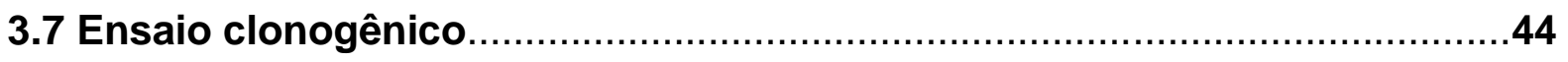

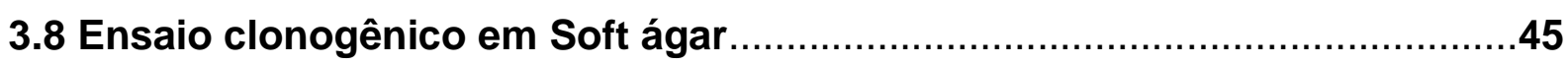

3.9 Curva de crescimento........................................................................ 45

3.10 Ensaio com fármacos................................................................45

3.10.1 Ensaio com drogas indutoras de dano ao DNA......................................46

3.11 Análise da expressão de proteínas..................................................46

3.11.1 Quantificação de proteínas...............................................................46

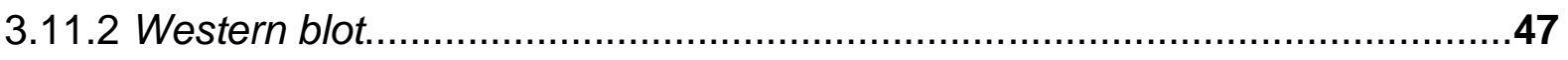


3.12 Análises estatísticas

4 RESULTADOS.

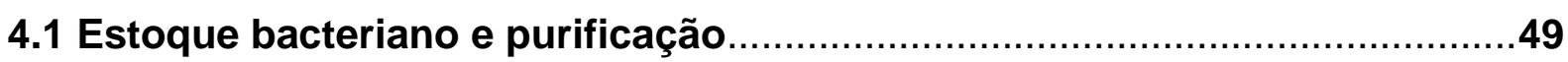

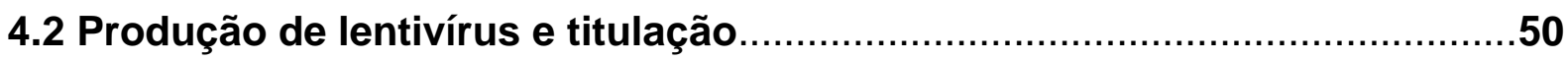

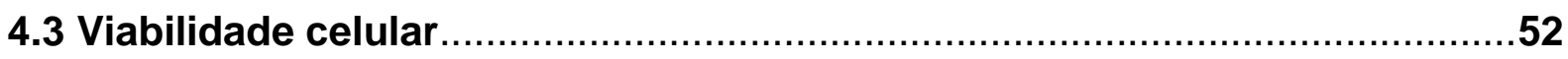

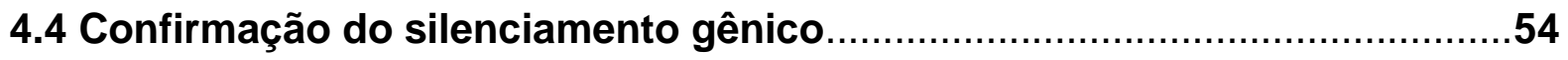

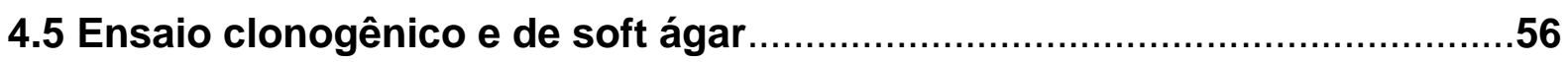

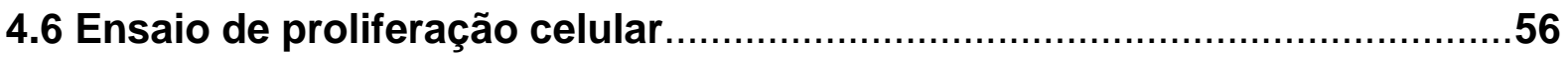

4.7 Efeito do silenciamento gênico em queratinócitos expressando as

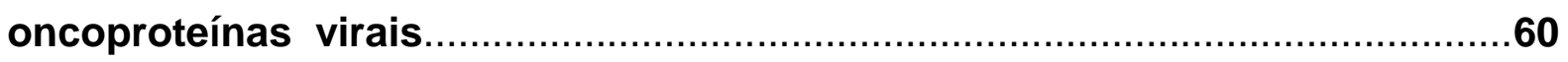

4.8 Efeito do uso de fármacos para a inibição de ATM e CHEK2 ........................61

4.9 Efeito da inibição de ATM e CHEK2 combinado a indução de danos DNA..66

4.9.2 Avaliação das linhagens de QHP transduzidas.............................................69

4.10 Níveis de ativação da via de ATM em células HeLa tratadas com inibidor

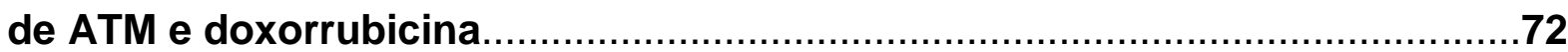

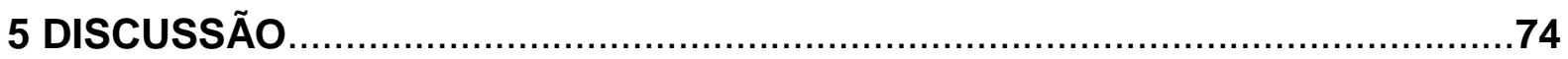

6 CONCLUSÕES

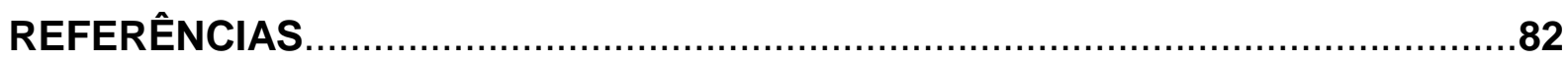




\section{INTRODUÇÃO}

\subsection{Biologia do HPV}

Os vírus do Papiloma (HPV) são vírus não envelopados, com capsídeo de simetria icosaédrica de aproximadamente $55 \mathrm{~nm}$, com genoma de DNA fita dupla circular de aproximadamente 8 mil pares de bases, que infectam pele, epitélios anogenital e mucosa da cavidade oral (IARC, 2007). São pertencentes a família Papillomaviridae, gênero Papilomavírus e são classificados por base da semelhança da sua sequência de nucleotídeos. São conhecidos cerca de 200 tipos de HPV (Bosch, 2002), dos quais cerca de 40 tipos são capazes de infectar a região anogenital e causar verrugas genitais, cistos epidérmicos, neoplasias intraepiteliais e até lesões displásicas de baixo e alto grau. Os HPV que infectam o trato anogenital podem ser divididos em baixo risco (HPV 6, 11, 40, 42, 43, 44, 55) e alto risco oncogênico (HPV 16, 18, 31, 33, 35, 39, 45, 51, 52, 56, 58 e 59), conforme o tipo de lesão associado a sua infecção (Clifford, 2003; Muñoz, 2003).

O genoma do HPV é dividido em três regiões funcionais distintas, que se distinguem nas sequências codificadoras precoces ( $E$ - Early) e tardias ( $L$ - Late) e a região regulatória não codificadora (LCR - Long Control Region) (Figura $1 \mathrm{~A}$ ). $\mathrm{A}$ região $\mathrm{E}$ codifica as proteínas precoces $\mathrm{E} 1, \mathrm{E} 2, \mathrm{E} 4, \mathrm{E} 5, \mathrm{E} 6$ e E7, as quais possuem diversas funções reguladoras envolvidas na persistência genômica, replicação do DNA viral, transcrição de genes virais e proliferação celular, enquanto a região tardia L é formada pelos genes L1 e L2 que codificam proteínas estruturais do capsídeo viral (Tabela 1) (Howley, 2007; McMurray et al., 2001; Souto, et al., 2005).

O ciclo de vida do vírus HPV está intimamente relacionado ao programa de diferenciação celular do epitélio (Campo, 2003). Os vírus são transmitidos pelo contato direto ou indireto com indivíduos que apresentam alguma microlesão e a infecção se inicia quando o HPV alcança as células da camada basal, as quais apresentam potencial replicativo. O genoma viral é mantido na forma epissomal e sua amplificação ocorre simultaneamente a replicação do DNA celular. Nesta primeira fase do ciclo, o genoma é mantido em um baixo número de cópias, com a expressão dos genes precoces E1 e E2, os quais formam um complexo multimérico capaz de promover a amplificação do genoma viral (Doorbar, 2005; Stubenrauch et al., 1999; Villa et al., 1998). A fase replicativa e a síntese proteica ocorrem nas 
camadas suprabasais do epitélio, onde ocorre a expressão das proteínas precoces (E1, E2, E4, E5, E6 e E7), as quais garantem maior amplificação do número de cópias do genoma viral e alterações celulares, que permitem a progressão do ciclo celular nas células em diferenciação (Madison, 2003).

A expressão das proteínas E6 e E7 são fundamentais para ultrapassar o bloqueio do ciclo celular nas células em diferenciação e garantir o funcionamento da maquinaria de replicação celular essencial para a amplificação do genoma viral. A proteína E7 induz a degradação da proteína do Retinoblastoma (pRb), a qual regula negativamente o ciclo celular (Chellappan et al., 1992). A proteína Rb na sua forma hipofosforilada se encontra ligada ao fator de transcrição E2F, o qual está envolvido na transcrição de vários genes envolvidos na fase $S$. Ao ser degradada pela ação de E7, a proteína Rb libera o fator de transcrição E2F e garante a ativação constitutiva dos genes envolvidos na progressão celular (Zur Hausen, 2000). A proteína E6 é capaz de se ligar ao fator de transcrição p53 e de recrutar a proteína E6AP, a qual age como uma ubiquitina ligase ao promover a ubiquitinação de p53 e levá-lo a degradação por via do proteassoma (Sherman, et al., 1997). Esta inativação de p53 impede a supressão do ciclo celular e consequentemente garante a continuidade do ciclo. Na camada granular ocorre a montagem das partículas virais a partir da expressão das proteínas estruturais do capsídeo L1 e L2. E por fim as partículas virais são liberadas na superfície pela descamação do epitélio, sem promover a lise da célula hospedeira (Figura 1B) (Doorbar, 2005; Howley, 2007). A retenção das partículas virais ao longo de todas as camadas de diferenciação celular, além de outros mecanismos que impedem a apresentação de epítopos virais nas camadas inferiores do epitélio, comprometem a detecção imunológica do vírus (Ashrafi et al, 2002; Marchetti et al, 2002; Matthews et al, 2003). Desta forma, o vírus HPV é capaz de se estabelecer e completar seu ciclo, mediante o processo de diferenciação do epitélio, sem ser percebido pelo sistema imunológico. 
A)

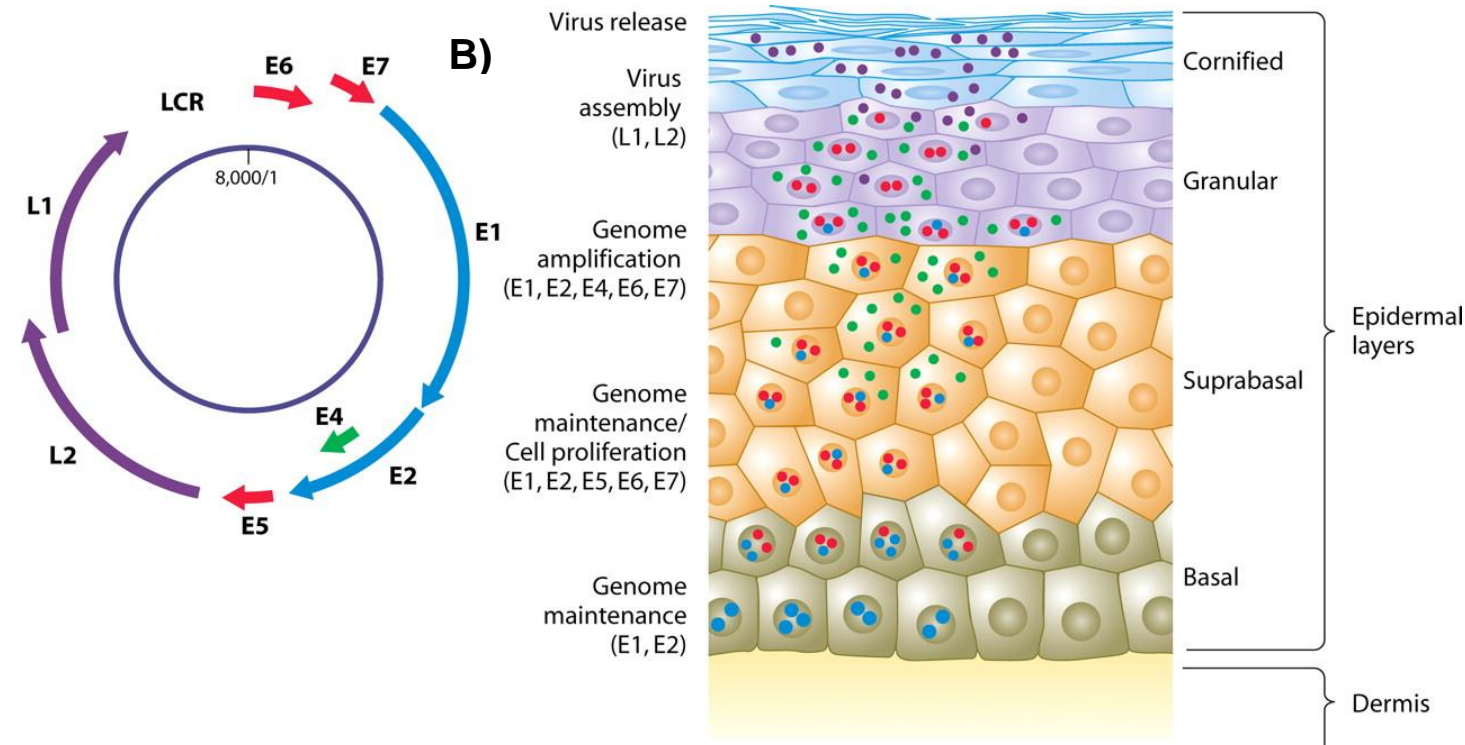

Figura 1 - Organização do genoma de HPV e o ciclo de vida viral. A) O genoma de HPV é composto de aproximadamente 8.000 pares de bases que se dividem em três regiões funcionais: a região regulatória não codificadora (LCR - Long Control Region) e a região que codifica as proteínas virais precoces ( $E$ - Early) e tardias (L - Late). B) O ciclo de vida do vírus HPV é dependente do programa de diferenciação celular e a expressão das proteínas virais se dão ao longo das diferentes camadas do epitélio, promovendo a manutenção e amplificação do genoma viral, proliferação celular, montagem e liberação das partículas virais. Fonte: (Lazarczyk et al., 2009)

Tabela 1 - Regiões do genoma de HPV com as suas respectivas funções.

\begin{tabular}{|c|c|c|}
\hline \multicolumn{2}{|c|}{ Regiões } & \\
\hline Precoces & $\begin{array}{l}\text { E1 } \\
\text { E2 } \\
\text { E4 } \\
\text { E5 } \\
\text { E6 } \\
\text { E7 }\end{array}$ & $\begin{array}{l}\text { Função de Helicase - Replicação viral. } \\
\text { Regulação da transcrição e replicação viral. } \\
\text { Alteração da matriz celular e maturação viral. } \\
\text { Estímulo da proliferação, transformação celular e evasão do } \\
\text { sistema imune. } \\
\text { Proliferação celular e transformação celular juntamente com } \\
\text { E7. E6 de HPV de alto risco promove a degradação de p53. } \\
\text { Proliferação celular e transformação celular juntamente com } \\
\text { E6. Inativa a proteína do retinoblastoma e permite progressão } \\
\text { do ciclo celular }\end{array}$ \\
\hline Tardias & $\begin{array}{l}\mathrm{L} 1 \\
\mathrm{~L} 2\end{array}$ & $\begin{array}{l}\text { Codifica a proteína maior do capsídeo. } \\
\text { Codifica a proteína menor do capsídeo. }\end{array}$ \\
\hline Regulatóri & LCR & $\begin{array}{l}\text { Apresenta a origem de replicação e promotores de } \\
\text { ranscrição. }\end{array}$ \\
\hline
\end{tabular}




\subsection{Câncer cervical e HPV}

O câncer de colo útero é uma transformação maligna que acomete a porção do colo uterino ou cérvix. Podem ser divididos histologicamente em dois principais tipos: carcinoma de células escamosas, o qual surge na ectocérvice e na junção escamo-colunar e adenocarcinoma, o qual surge no epitélio grandular da endocérvice (Figura 2). O câncer cervical é o quarto tipo de tumor mais frequente em mulheres no mundo com aproximadamente 527 mil novos casos e 265 mil mortes ao ano (Globocan, 2012). No Brasil, o câncer cervical é o terceiro tipo de tumor mais frequente em mulheres, atrás apenas do câncer de mama e do coloretal, sendo responsável por cerca de 5 mil mortes ao ano (Inca, 2013).

As primeiras evidências de associação do câncer cervical e o HPV surgiram na década de $70 \mathrm{com}$ pesquisas que mostravam uma semelhança entre as alterações morfológicas encontradas no câncer de colo de útero com as observadas em condilomas (Meisels e Fortin, 1976). Somente na década de 80 foi detectado a presença do HPV em amostras de câncer cervical, o que levou ao pesquisador Harald zur Hausen a propor uma relação direta entre o câncer cervical a infecção viral (Boshart et al., 1984; Durst et al., 1983). O estabelecimento desta associação acarretou em inúmeros estudos da biologia do vírus HPV e de sua capacidade oncogênica.

Hoje já se sabe que cerca de $99,7 \%$ dos cânceres da cérvix uterina estão associadas à infecção persistente por Papilomavírus Humano de alto risco oncogênico. Os HPVs de alto risco 16 e 18 são responsáveis por cerca de $70 \%$ dos casos de câncer de colo de útero e são os dois tipos de HPV mais prevalentes, tanto nas infecções assintomáticas (Bruni et al., 2010; De Sanjosé et al., 2007) quanto nos casos de câncer cervical (Li et al., 2011, De Sanjosé, et al., 2010). Por outro lado, os HPV 6 e 11 de baixo risco oncogênico estão presentes em mais de $90 \%$ dos condilomas (Anic et al, 2011; Chan et al., 2009).

A capacidade do HPV em induzir a carcinogênese está atribuída à função das proteínas E6 e E7. A expressão destas é suficiente para induzir imortalização de queratinócitos humanos primários derivados de prepúcio de recém nascido (QHP) in vitro (Liu et al., 1997). A proteína E6 de HPV de alto risco oncogênico associa-se à proteína p53, a qual tem atividade supressora de tumor e recruta proteínas celulares, como E6-AP, a qual tem função de ubiquitina ligase 
(Kisseljov, 2000; Scully, 2002; Zur Hausen, 2002). O complexo E6/E6-AP leva p53 à degradação através da via de proteólise dependente de ubiquitina, diminuindo os níveis de p53 nas células infectadas (Scheffner e Whitaker, 2003). Já a proteína E7 associa-se às proteínas da família pRb. Essa interação inativa pRb, a qual se desliga do fator E2F, permitindo a progressão do ciclo celular (Kastan e Bartc, 2004)

A expressão destas proteínas oncogênicas não é suficiente para 0 desenvolvimento de um tumor maligno, sendo necessários eventos genéticos adicionais, como a integração do DNA viral no genoma celular (Figura 3). A integração do genoma do HPV é um evento aleatório, que normalmente ocorre através da região E1 e E2 do genoma viral. A consequência desta integração é uma perda da função destas proteínas, a qual leva à expressão constitutiva dos genes E6 e E7, que promove instabilidade genômica e contribuem para o acúmulo de danos ao DNA (Chen, 2010; Méhes et al., 2004). Células transformadas por HPV apresentam a expressão constitutiva das oncoproteínas E6 e E7 de HPV, as quais agem em vias de transdução de sinais, sobretudo as reguladas por p53 e pRb (Munger et al., 1989; Narisawa-Saito e Kiyono, 2007; Zur Hausen, 2002;). Estas proteínas são capazes de promover a progressão do ciclo celular, desalinhamento dos cromossomos, mitose multipolar e consequentemente levando a aneuploidia e poliploidia (Duensing e Munger, 2002; Duensing et al., 2000; Hashida e Yasumoto, 1991; Heliman et al., 2009; Kadaja et al,. 2009; Liu et al., 2007). Além disso, estas proteínas modulam a resposta celular de dano ao DNA, alterando mecanismos de resposta ao stress oxidativo, de reparo por excisão de nucleotídeos (NER), induzindo quebras de fita DNA e aumentando a integração de DNA exógeno ao genoma das células hospedeiras (Gillespie et al., 2012; Kessis et al., 1993; Lembo et al., 2006; Therrien et al., 1999). 


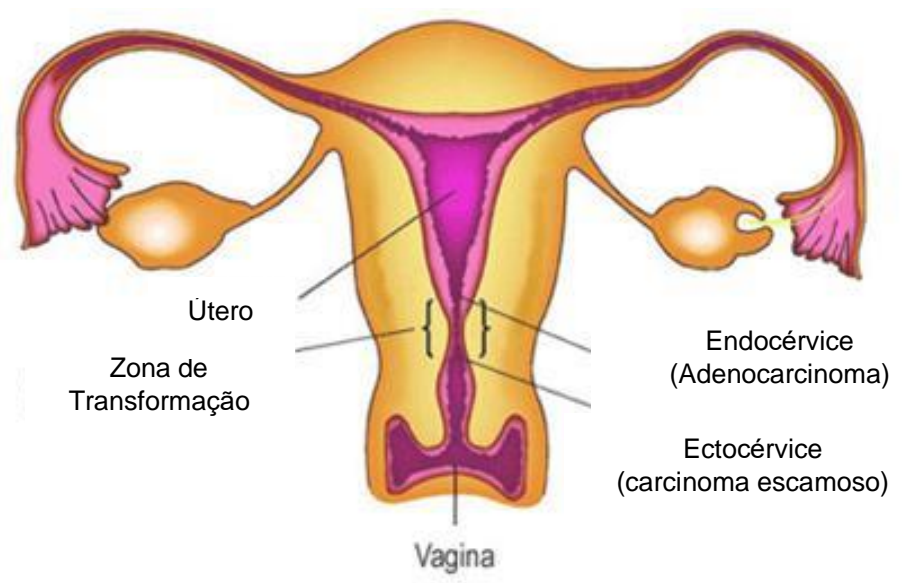

Figura 2 - Estrutura do colo uterino. O colo uterino é anatomicamente dividido em duas porções: ectocérvice e endocérvice. A ectocérvice, a qual está em conato com a vagina, é revestida por um epitélio escamoso, que pode originar o câncer escamoso. A endocérvice é a porção interna do colo uterino revestida por um epitélio grandular, o qual pode originar um adenocarcinoma. A região que conecta a endocérvice a ectocérvice é chamada de zona de transformação, local em que se desenvolve a maioria dos tumores de colo de útero.

\section{Cervical Cancer}

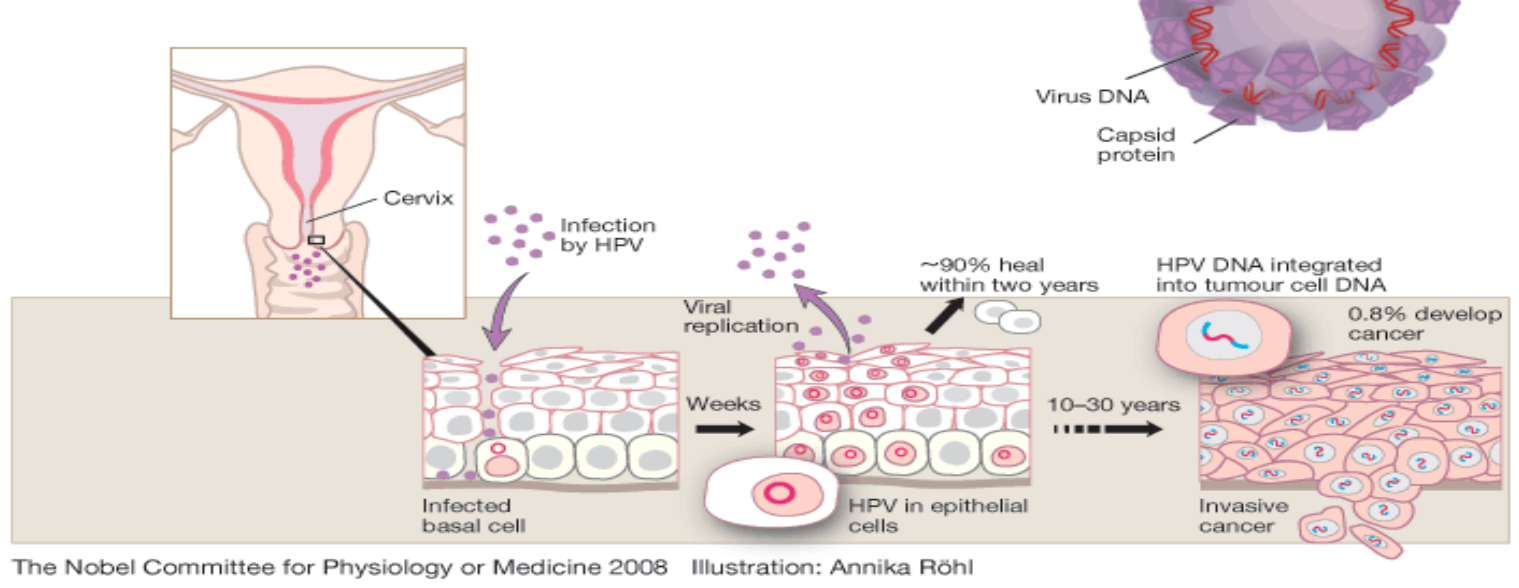

Figura 3 - Infecção do vírus HPV e o processo de carcinogênese. O vírus HPV infecta a camada basal do epitélio a partir de microlesões do epitélio, onde se mantêm na forma epissomal e em baixos números de cópias. O ciclo replicativo viral ocorre simultaneamente ao processo de diferenciação celular do epitélio, sendo liberadas novas partículas virais pela descamação da camada córnea. Infecções persistentes por HPV de alto risco podem favorecer a integração do genoma viral no genoma da célula hospedeira. Este processo de integração interrompe a expressão das proteínas virais E1 e E2, as quais regulam negativamente as oncoproteínas virais E6 e E7. O aumento da expressão de E6 e E7 acarretam em uma maior proliferação celular, gerando instabilidade genética o que pode culminar no desenvolvimento do câncer cervical. Fonte: The Nobel Committee for Physiology or Medicina 2008, Harald zur Hausen, Françoise Barré-Sinoussi, Luc Montagnier. 


\subsection{Mecanismos de reparo de dano ao DNA}

O genoma celular está constantemente sofrendo danos causados por fatores endógenos oriundos do processo replicativo, tais como oxidação, alquilação e erros no pareamento de bases. Além de danos exógenos causados por fatores externos, tais como radiação, quimioterápicos, toxinas e vírus (Figura 4). Estes danos acarretam em alterações genéticas, tais como mutações, crosslinks e danos à fita simples e à fita dupla de DNA (Lindahl, 1993; Nakamura, 2014). Estes danos podem levar à alterações das vias celulares, promovendo uma desregulação dos processos bioquímicos que regulam crescimento, proliferação e replicação do genoma celular.

Para preservar a integridade do genoma, as células apresentam inúmeros mecanismos, os quais detectam estes danos, inicia uma resposta apropriada de reparo ao dano, promove a parada do ciclo celular, repara o DNA ou induz a morte celular por apoptose. Estes processos são altamente regulados pela atividade da maquinaria de reparo de dano ao DNA, a qual promove a correção destas lesões e garante a integridade da informação genética. Todavia, uma vez que o DNA não é reparado e não ocorre a indução da morte celular, estas células podem progredir no ciclo celular carregando estas mutações, as quais podem no futuro levar ao surgimento do câncer (Lindahl, 1993; Sancar et al., 2004, Sulli et al., 2012).

A maquinaria de reparo apresenta sensores, tais como o complexo MRN (MRE11-Rad50-Nbs1) e a proteína de replicação A (RPA), os quais detectam lesões causadas ao DNA e recrutam outras proteínas, tais como ataxia telangiectasia mutada (ATM) e ataxia telangiectasia e Rad3 relacionados (ATR) transdutor de quinases para o local do dano. Tanto ATM quanto ATR respondem ao dano de DNA, porém estudos mostram que ATM responde principalmente a danos de quebra de fita dupla, ao passo que ATR responde melhor as lesões causadas pela radiação UV ou agentes intercalantes de DNA (Hekmat-Nejad et al., 2000; Lowndes e Murguia, 2000; Pandita et al., 2000; Wright et al., 1998). Quando ativadas ATR e ATM sofrem uma autofosforilação, induzindo uma cascata de sinalização, levando a ativação das quinases efetoras Chek1 e Chek2, respectivamente (Zhou e Elledge, 2000). Esta ativação promove a parada do ciclo celular nas fase $\mathrm{G} 1$, S ou G2 e permite que a maquinaria de reparo de DNA atue sobre o DNA danificado. Caso o dano não seja reparado, a célula pode iniciar o processo de morte celular (Figura 5). 
Os danos causadas à fita simples, ocorrem quando somente uma das fitas de DNA é lesionada, mas a outra permanece intacta e pode ser utilizada como fita complementar para orientar o reparo de DNA. O reparo de danos à fita simples podem ser realizados pelos mecanismos de excisão de base (BER - Base excison repair) ou de nucleotídeos (NER - Nucleotide excision repair) e reparo de bases mal pareadas (MMR - Mismatch repair).

O mecanismo de reparo de excisão de base ocorre em um determinado nucleotídeo, mediante danos causados por oxidação, alquilação, hidrólise e desaminação. $O$ reconhecimento da base nitrogenada alterada é feito por enzimas da família das DNA glicosilases, as quais iniciam o processo de reparo, removendo a base modificada e gerando um sítio apurínico. Este sítio é posteriormente removido pela atividade de endonucleases e restaurado pela DNA polimerase, com base na homologia da fita complementar de DNA (Hoeijmakers, 2001).

O mecanismo de excisão de nucleotídeos é ativado a partir de lesões que provocam distorções na dupla fita de DNA. Estas lesões podem ser ocasionados por diversos fatores, tais como dímeros de pirimidina ciclobutano (CPDs) e pirimidina (64) pirimidona fotoprodutos (6-4PPs), ocasionada pela luz UV. Diferente do mecanismo BER, a qual remove somente a base alterada, este mecanismo irá remover uma sequência de nucleotídeos. O mecanismo de reparo por excisão de nucleotídeo é um mecanismo altamente versátil, que reconhece uma ampla variedade de lesões, sendo dividido em duas principais subvias: o reparo do genoma global (GGR), o qual repara lesões presentes em qualquer ponto do genoma, e o reparo acoplado a transcrição (TCR), que irá reparar regiões lesionadas de genes em transcrição (Marteijn et al. 2014).

O reparo de bases mal pareadas ocorre mediante erros da replicação e da recombinação gênica durante a meiose. Bases nitrogenadas pareadas erroneamente são identificadas por um complexo proteico, o qual remove esta base e uma DNA polimerase sintetiza um nucleotídeo correto. Em eucariotos este complexo diferencia a fita recém sintetizada da fita molde a partir da descontinuidade encontrada, como terminações $3^{\prime}$ ou fragmentos de Okazaki (Constantin et al. 2005; Dzantiev et al. 2004; Fang e Modrich, 1993; Modrich, 2006).

Os danos de fita dupla são ocasionados sobretudo por radiação ionizante, stress replicativo, intermediários metabólicos reativos e espécies reativas de oxigênio (ROS). Estes danos podem ser reparados por Recombinação não 
Homóloga (Non-Homologous End-Joining - NHEJ), ou por Recombinação Homóloga (Homologous Recombination - HR) (Hoeijmakers, 2001). O reparo realizado por Recombinação não Homóloga apresenta baixa fidelidade, estando sujeito à erros e podendo apresentar perdas de informação genética (Lieber et al. 2003). Já o reparo realizado pelo mecanismo de Recombinação Homóloga apresenta alta fidelidade, garantindo um reparo mais eficiente a partir de uma fita molde. O mecanismo pelo qual a célula decide reparar danos de fita dupla está relacionado com a presença de uma fita complementar, ou seja uma fita molde (Hoeijmakers, 2001). A recombinação homóloga ocorre especialmente na presença de uma fita molde, logo estando restrito as fases $S$ e G2 do ciclo celular. A ausência de uma fita molde, necessária para a via de recombinação homóloga, levaria a célula a reparar o dano por recombinação não homóloga.

Todos estes mecanismos estão envolvidos e altamente regulados para garantir a integridade da informação genética. Entretanto, falhas neste sistema podem ocorrer e levar ao surgimento mutações, as quais podem ser mutações com ganhos ou perdas de funções, ou mutações letais. Mutações ocorridas em genes envolvidos nos processos de replicação e proliferação celular podem acarretar em um descontrole do processo replicativo. Os proto-oncogenes são genes envolvidos no aumento da proliferação celular, os quais podem sofrer mutações e se tornarem permanentemente ativos. Estas alterações em um proto-oncogene pode promover um crescimento descontrolado das células e este torna-se um oncogene, ou seja, um gene cujo produto ativo leva a um crescimento celular desregulado (BorgesOsório, 2001). Este crescimento sem controle, pode levar ao acúmulo de danos, culminando em uma instabilidade genômica e ao estabelecimento de um tumor. 


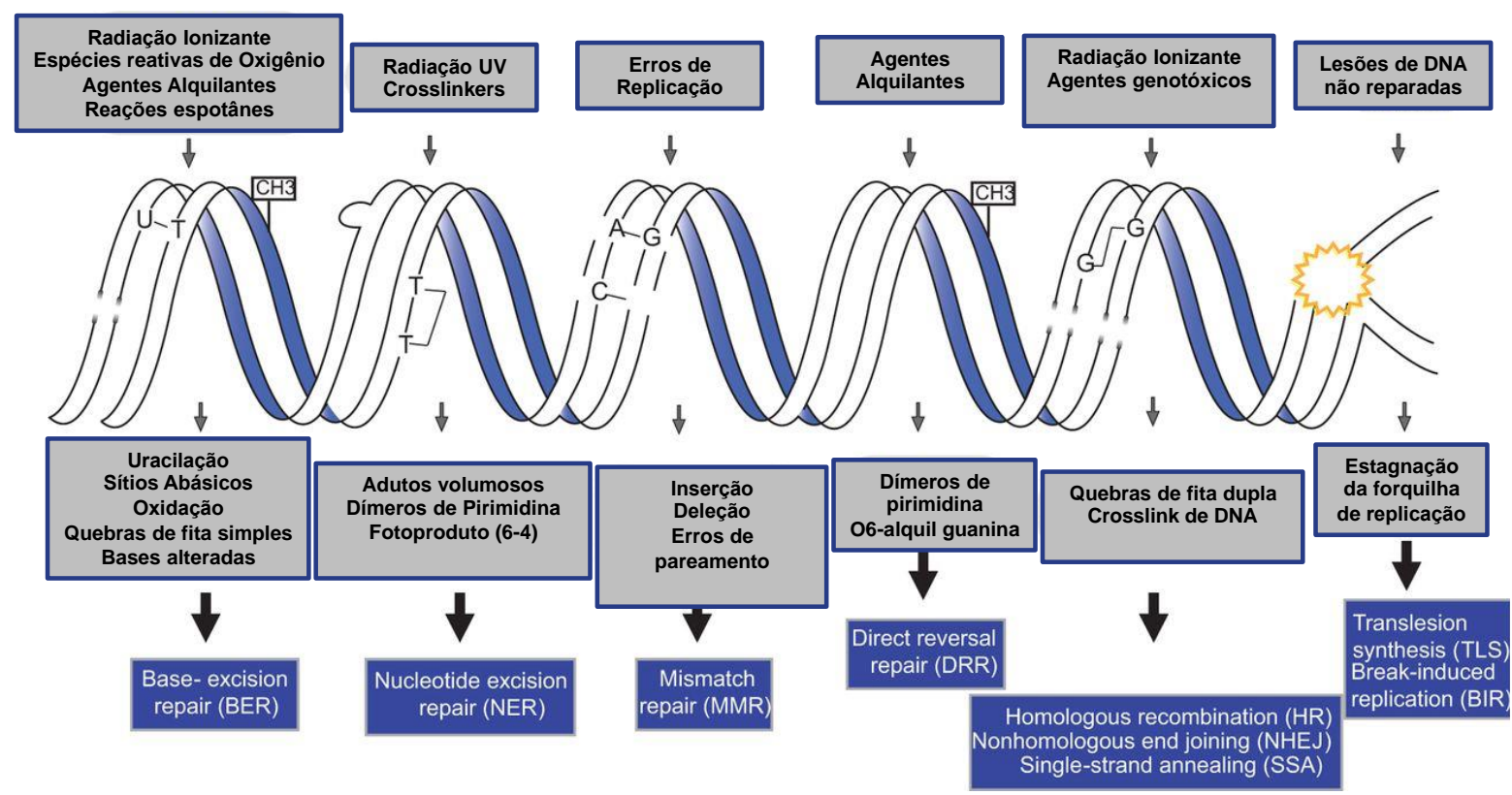

Figura 4 - Fonte de danos ao DNA e os mecanismos de reparo. O DNA celular está sujeito ao ataques de diferentes agentes causadores de dano, os quais podem ser exógenos (agentes externos como radiação UV) ou endógenos (agentes internos como espécies reativas de oxigênio). Estes agentes causam os mais variados tipos de lesões ao DNA, que ativam mecanismos celulares específicos de reparo ao DNA. Os danos de DNA podem ser de quebras de fitas simples, dupla, formação de dímeros, sítios abásicos, inserções, deleções e modificações de base. Os mecanismos de reparo respondem a cada tipo de lesão, conforme a sua especialidade. (Modificado de Gênios et al., 2014) 


\section{xovax}

\section{DNA damage sensors}

Apical kinases

DNA damage mediators

Downstream kinases

Effectors

Outcomes

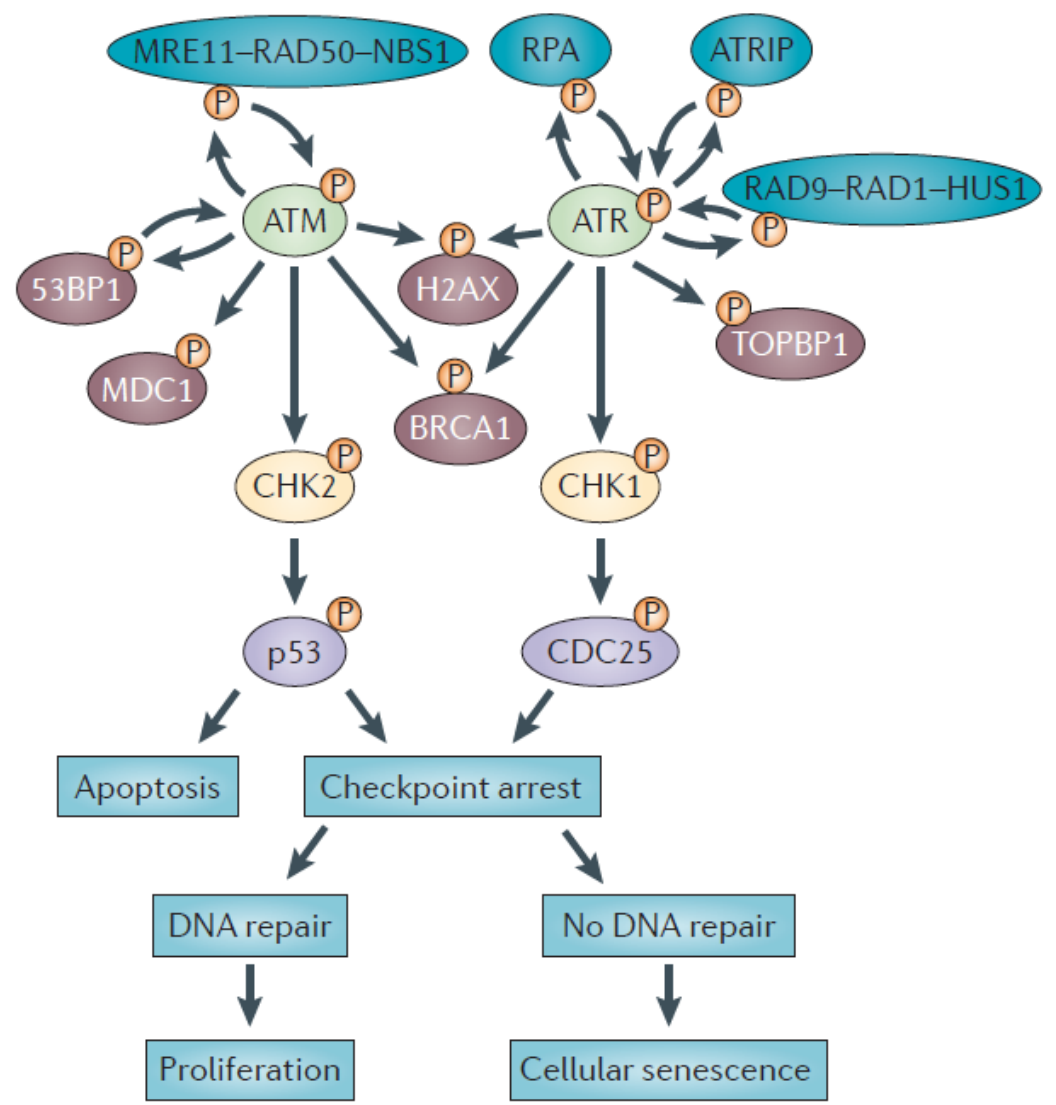

Figura 5 - Vias de sinalização em resposta ao dano ao DNA. A resposta ao dano de DNA é composta por dois principais sensores: O complexo MRN (MRE11-RAD50NBS1), o qual detecta danos à fita dupla de DNA; e a proteína de replicação $A$ (RPA) e o complexo RAD9-RAD1-HUS1 (9-1-1), envolvidos na detecção da danos à fita simples de DNA. O complexo MRN recruta a proteína ataxia telangiectasia mutada (ATM) e RPA e o complexo 9-1-1 recruta a proteína ataxia telangiectasia e Rad3 relacionados (ATR) para o local do dano. A ativação destas proteínas leva a uma cascata de sinalização que culminam na ativação de proteínas efetoras que promovem a parada do ciclo celular, reparo do DNA, senescência ou apoptose. (Fonte: Sulli et al., 2012) 


\subsection{HPV e a maquinaria de reparo de DNA}

A maquinaria de reparo de DNA é crucial para manutenção e estabilidade genômica durante a replicação e progressão do ciclo celular. Porém, diferentes estudos vem mostrando a importância da maquinaria de reparo na manutenção e amplificação do genoma do vírus HPV (Gillespie et al., 2012; Moody e Laimins, 2009; Reinson et al., 2013; Sakakibara et al., 2011). Desta forma, as proteínas virais podem ativar ou inibir proteínas da maquinaria de reparo, garantindo a continuidade do seu ciclo replicativo. Estas observações sugerem que a maquinaria de reparo de DNA pode desempenhar um papel duplo na biologia do HPV, mantendo a integridade do DNA celular e promovendo a amplificação do genoma viral.

As proteínas E1 e E2 recrutam a maquinaria de reparo de DNA para os sítios de replicação viral, garantindo a amplificação do genoma de HPV (Fradet-Turcotte et al., 2011; Reison et al., 2013). A atividade de helicase não específica de E1 é capaz de induzir danos ao DNA da célula hospedeira, promovendo a fosforilação da histona H2AX, a qual sinaliza e ativa proteínas das vias de ATM e ATR (Reison et al., 2013). O processo pelo qual ocorre o recrutamento destas proteínas não é ainda bem elucidado, porém diversos experimentos apontam uma colocalização do complexo de replicação viral e as proteínas da maquinaria de reparo, tais como ATRip, TOPbp1, phospho-ATM, phospho-H2AX, phospho-p53, Chk1, Chk2, PCNA, RPA, Nbs1, 53bp1, BRCA1 e RAD51. (Fradet-Turcotte et al., 2011; Gillespie et al., 2012; Moody e Laimins, 2009; Reison et al., 2013; Sakakibara et al., 2011) (Figura $6)$.

O genoma viral no inicio da infecção é mantido em baixo números de cópias e se replica juntamente com o genoma das células hospedeiras. A medida que ocorre a parada do ciclo celular e a diferenciação do epitélio, aumenta-se o número de cópias do genoma viral e consequentemente a importância da maquinaria de reparo de DNA para promover a amplificação do genoma viral. Esta transição da fase de manutenção para a fase de amplificação do genoma viral é marcada por um aumento do tamanho do sítio de replicação viral (Gillespie et al., 2012). As proteínas E6 e E7 são altamente expressas nesta etapa de amplificação e apresentam papel fundamental ao modular o ciclo celular e garantir que as células em diferenciação mantenham a sua maquinaria de replicação e reparo ativas, para que o genoma viral 
seja amplificado. A proteína E7 garante a continuidade do ciclo celular ao degradar pRb e a apoptose é evitada pela degradação de p53 por meio da atividade de E6.

$\mathrm{O}$ bloqueio entre a fase G1/S é realizado pela atividade das proteínas da família pocket (pRb, p107 e p130) juntamente com o fator de transcrição E2F. A proteína E7 é capaz de interagir com estas proteínas da família pocket e promover a liberação do fator E2F, permitindo a continuidade do ciclo celular. Além disso, a proteína E7 é capaz de ultrapassar o checkpoint G1/S ao degradar a proteína de ligação de CHEK1 (Claspin) e consequentemente impedir a parada do ciclo por meio da via de ATR (Spardy et al., 2009). A desregulação do fator E2F promove o aumento da proteína CHEK2, a qual estaria envolvida no processo de amplificação viral (Rogoff et al., 2004). No epitélio estratificado a expressão da proteína E7 leva ao aumento e acúmulo do complexo MRN (MRE11-RAD50-NBS1) e das proteínas envolvidas no mecanismo de recombinação homóloga $(H R)$, além de ativar a via de ATM e interagir com a proteína de reparo NBS1, as quais são necessárias para a amplificação do genoma viral (Anacker et al., 2014; Hong e Laimins et al.,2013; Moody e Laimins, 2009;).

A ativação e recrutamento das diferentes proteínas da maquinaria de reparo, por intermédio das proteínas virais E1, E2 e E7, culminam na ativação da proteína p53, a qual induz a expressão do gene p21. A proteína p21 se liga aos complexos ciclina-Cdk2 ou -Cdk4 inibindo a atividade destes complexos e interrompendo o ciclo celular (el-Deiry et al., 1993; el-Deiry et al., 1994). Esta parada do ciclo celular, iniciada pela atividade de p53, implicaria em uma interrupção do ciclo replicativo viral. Além da sua função de controle do ciclo celular, a proteína p53 é capaz de interagir diretamente com E2 e impedir a amplificação viral (Figura 6) (Brown et al., 2008). Assim, a habilidade da proteína $E 6$ em promover a degradação de p53 é crucial para a manutenção, amplificação e persistência viral (Flores et al., 2000; Park et al., 2002; Thomas et al., 1999). Vírus que são incapazes de degradar p53 não conseguem transpor a barreira imposta por p53 e consequentemente não conseguem amplificar o seu genoma (Kho et al., 2013). Portanto, o vírus HPV é capaz de ativar a maquinaria de reparo de dano ao DNA para promover a amplificação do seu genoma, porém inibem determinadas proteínas desta maquinaria, as quais poderiam interromper o seu ciclo produtivo. 


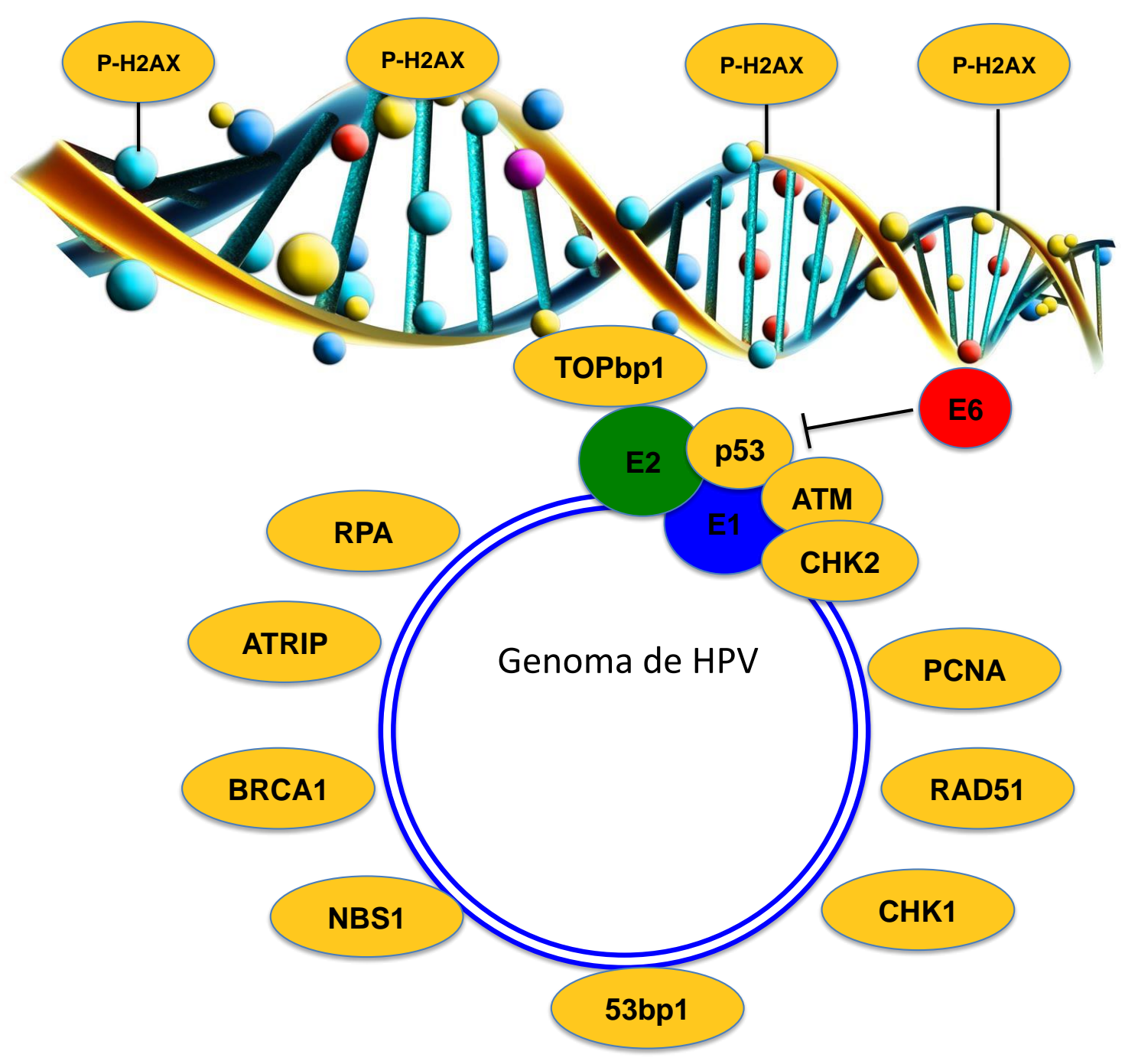

Figura 6 - Replicação Viral e a Maquinaria de Reparo de Dano ao DNA. As proteínas E1 e E2 de HPV são capazes de recrutar proteínas da maquinaria de reparo para o centro replicativo viral. A proteína $\mathrm{E} 2$, em especial, promove a conexão do genoma viral ao genoma celular por meio da interação com a proteína TOPbp1. As proteínas E1 e E2 interagem diretamente com as proteínas sinalizadoras p53, ATM e CHK2, além de se encontrarem colocalizadas com marcadores para dano de DNA (P-H2AX). Estas proteínas interagem com genoma de HPV, auxiliando na manutenção e amplificação do genoma viral. (Modificado de Wallace e Galloway, 2014) 


\subsection{Instabilidade genômica}

A instabilidade genômica é frequentemente associada ao desenvolvimento tumoral e tem sido amplamente utilizado no prognóstico de câncer. Técnicas moleculares são utilizadas na caracterização das células cancerosas e permitem detectar um padrão complexo de alterações cromossômicas em lesões precursoras do carcinoma da cérvice uterina, incluindo ganhos em 1p, $6 p$ e 9q e perdas em 3p, 3q, 4q, 5q e 13q (Alazawi et al., 2004; Giannoudis et al., 2000; Wistuba et al., 1997). Alterações nos mecanismos de controle do ciclo celular podem levar em anomalias genéticas, as quais incluem translocações, aneuploidias, poliploidias, deleções, amplificações, duplicações ou inversões de genes.

As oncoproteínas virais E6 e E7 de HPV são capaz de induzir a desregulação do ciclo celular, recrutando proteínas da maquinaria de reparo de DNA para o sítio de replicação viral e inibindo a atividade das proteínas dos checkpoints. Desta forma, E6 e E7 eliminam as barreiras impostas pelo ciclo celular e conseguem transpor os pontos de controle, levando a uma instabilidade genômica e contribuindo para o acúmulo de danos ao DNA. Além disso, estas proteínas agem em vias de transdução de sinal, as quais estão alteradas na maioria dos tumores não associados a este vírus, como é o caso das vias reguladas por p53 e pRb, entre outras (Chen et al., 2010; Méhes et al., 2004).

A presença das oncoproteínas de HPV está relacionada a inúmeras alterações nos mecanismos de reparo de DNA, os quais envolvem deficiência nos mecanismos de reparo por excisão de nucleotídeos global e acoplado a transcrição (GGR e TCR), ineficiência dos mecanismos de reparo de danos ao DNA causados por estresse oxidativo, radiação UV, radiação ionizante e alquilação. (Giampieri e Storey, 2004; Lembo et al., Rey et al., 1999; 2006; Shin et al., 2006; Srivenugopal e Ali-Osman 2002; Therrien et al., 1999). Além disso, E6 e E7 de HPV de alto risco induzem quebras no DNA e aumentam a integração de DNA exógeno no genoma da células hospedeira (Duensing e Münger, 2002; Kessis et al., 1993).

A proteína E6 além de promover a inativação de p53, ela interrompe inúmeras vias de reparo, garantindo que estas não parem o ciclo celular ou induzam a apoptose mediante o acúmulo de danos de DNA. Desta forma, E6 é capaz de retardar a atividade da proteína Rad3-related protein (ATR), além de interagir com as proteínas XRCC1 e O6methylguanine-DNA methyl-transferase, todas envolvidas 
no reparo de danos à fita simples (SSBs) (Iftner et al., 2002; Srivenugopal e AliOsman, 2002; Wallace et al., 2012). E6 ainda é capaz inativar a maquinaria de reparo de danos à fita dupla (DSBs), a partir da interação com as proteínas BRCA1 e BARD1, porém o mecanismo pelo qual ocorre esta inativação ainda não está claramente elucidado (Yim et al., 2007; Zhang et al., 2005). Além disso, a oncoproteína E6 está relacionada com a inibição de vias intrínsecas e extrínsecas de ativação da apoptose, promovendo a redução dos níveis de fatores próapoptóticos da família Bcl2 (Bak e Bax) e aumentando os níveis dos fatores antiapoptóticos, tais como IAP-2 e Survivina (Borbely et al., 2006; Jackson et al., 2000; James et al., 2006; Thomas e Banks; 1998; Thomas e Banks, 1999; Tomlins e Storey, 2010; Underbrink et al., 2008; Yuan et al., 2005)

Já a oncoproteína $E 7$, por sua vez, além de promover a degradação de pRb, ela tem a capacidade de interagir com NuMa (Nuclear mitotic apparatus protein) e com gamma-tubulina, promovendo a desregulação dos microtúbulos e duplicação de centrossomos, o que leva a falhas no alinhamento dos cromossomos e a mitose multipolar (Nguyen et al., 2007; Nguyen et al., 2008). Erros no processo mitótico, juntamente com a desregulação do ciclo celular, resultam em anomalias celulares, tais como poliploidias e aneuploidias (Duensing et al., 2000; Hashida e Yasumoto, 1991). E7 também está envolvido na inativação, mas não na degradação de BRCA1, impedindo desta forma que ocorra a inibição da transativação dos promotores de cMyc e da telomerase reversa humana (hTERT), por meio de BRCA1 (Zhang et al., 2005).

Em conjunto, estas observações descritas indicam que as oncoproteínas de HPV promovem instabilidade genômica e contribuem para o acúmulo de danos no DNA. No entanto, o efeito da infecção por HPV e o impacto da expressão das oncoproteínas virais na expressão de genes associados aos mecanismos de reparo de dano ao DNA não têm sido explorados de maneira sistemática. 


\subsection{Silenciamento gênico e letalidade sintética}

O silenciamento gênico mediado por RNA de interferência (RNAi) é um mecanismo pós-transcricional natural e conservado, que ocorre na maioria dos eucariotos (Hannon, 2002). Este mecanismo atua sobre o RNA mensageiro (RNAm) celular a partir de uma sequência de nucleotídeos complementar, que leva a formação de uma fita dupla de RNA (dsRNA - double stranded RNA). A supressão da expressão gênica ocorre pela formação de RNA fita dupla dentro da célula e que por mecanismos conservados ao longo da evolução celular é levado para vias de degradação (Bernstein et al., 2001; Elbashir et al., 2001).

O RNA de interferência foi descrito pela primeira vez em 1998 a partir de estudos com Caenorhabditis elegans, quando obervaram que a presença de moléculas de RNA dupla fita impediam a expressão gênica do RNAm (Fire, et al.,1998). Em 2006, os pesquisadores Andrew Z. Fire e Craig C. Mello receberam o Prêmio Nobel de Medicina e Fisiologia pela descoberta do RNA de interferência. Desde a sua descoberta, a tecnologia de RNAi vem sendo amplamente desenvolvida em diferentes modelos e tornou-se uma ferramenta usual para 0 silenciamento gênico. É um processo simples e de alta especificidade, que garante redução eficiente da expressão dos genes de interesse a partir da complementariedade de bases do RNAi com o RNA mensageiro celular. Esta propriedade de regulação pós-transcricional torna o RNAi um método de grande utilidade para a investigação de determinados genes nas funções celulares (Bettencourt-Dias et al., 2004; Boutros et al., 2004).

Estudos utilizando RNAi comerciais em células humanas foram capazes de identificar moduladores de apoptose induzidos por TRAIL (Aza-Blanc et al., 2003) e kinases essenciais em células humanas infectadas por HPV (Baldwin, 2010). A técnica de RNAi muitas vezes é ineficiente pela metodologia adotada de entrega à célula alvo. Lentivírus replicantes-incompetentes tem se demonstrado excelentes vetores de transferências de small hairpin RNA (shRNA), precursores de small interfering RNAs (siRNA) dentro das células infectadas (Lebedev et al., 2013). Os shRNAs contém a sequência dos siRNA, as quais não ultrapassam 30 pb e portanto não são capazes de acionar os mecanismos de resposta antiviral da célula (Elbashir et al., 2001). Após a infecção das células alvo, os shRNA sintetizados no núcleo são clivados em fragmentos de 21-25 nucleotídeos, formando um duplex de siRNA, por 
uma nuclease conhecida como Dicer (Yi et al., 2003) (Figura 7). Este duplex corresponde às fitas sense e antisense do RNA alvo, o qual se associa ao complexo RISC (RNA Interference Specificity Complex) (Tomari et al., 2005). Este complexo tem a função de helicase e abre a dupla fita do siRNA, permitindo que a fita antisense direcione o complexo até o RNAm alvo, o qual é clivado e posteriormente degradado (Martinez et al., 2005; Yi et al., 2003).

Esta técnica tem sido amplamente utilizada para estabelecer a existência de letalidade sintética, assim como descrever os pares letais relacionados. A Letalidade Sintética foi descrita pela primeira vez pelo geneticista americano Calvin Bridges no início do século 20, porém somente 20 anos mais tarde o termo foi cunhado por Dobzhansky, após trabalhos conduzidos em Drosophila pseudoobscura (Bridges, 1922; Dobzhansky, 1956; Nijman, 2011). É definida como uma interação genética que surge quando uma combinação de mutações em dois ou mais genes não alélicos e essências leva à morte das células, enquanto que a mutação em apenas um desses genes não altera a viabilidade celular. A letalidade sintética também pode ocorrer quando um gene é inativado por mutação e outro gene é inativado através de inibidores específicos ou pela expressão de proteínas virais. Este princípio foi utilizado para estabelecer a existência de letalidade sintética entre os genes Breast Cancer 1 e 2 (BRCA1 e BRCA2), os quais são supressores de tumor que estão relacionados a câncer de mama e ovário quando mutados, com a proteína PARP, também relacionada a reparo de DNA (Fong, 2009; Fong, 2010). Pacientes com tumores que apresentam estas mutações em BRCA1 ou BRCA2 podem ser tratados com sucesso utilizando um inibidor químico de PARP com efeitos colaterais leves (Mendes, 2009). Este conceito pode também ser aplicado em células tumorais infectadas por HPV de alto risco, uma vez que as oncoproteínas E6 e E7 promovem instabilidade genômica, contribuem para o acúmulo de danos ao DNA e agem em vias de transdução de sinal, as quais estão alteradas na maioria dos tumores não associados a este vírus, como é o caso das vias reguladas por p53 e pRb, além de outras (Chen, 2010; Méhes et al., 2004). Trabalho recentes descreveram a existência de letalidade sintética entre a proteína p53 e as quinases PAK3 e SGK2 em células transformadas por HPV (Baldwin et al., 2010). Nestas células, as quinases PAK3 e SGK2 foram inativadas por lentivírus que carregavam shRNA específicos e a inativação de p53 pela expressão da oncoproteína E6 de HPV16. A busca destes pares letais associados a alterações moleculares de células 
carcinogênicas representa uma excelente oportunidade terapêutica.

No presente estudo, silenciamos de maneira sistemática genes envolvidos nas diferentes vias de reparo de dano ao DNA e genes supressores de tumor em linhagens derivadas de carcinomas de colo uterino visando determinar a existência de letalidade sintética entre os genes silenciados e àqueles cuja atividade é alterada pela presença do HPV. Este estudo possibilita desenvolver novas estratégias para o tratamento de lesões associadas a este vírus e que possivelmente poderão ser aplicadas ao estudo de outros tumores de origem viral ou não.

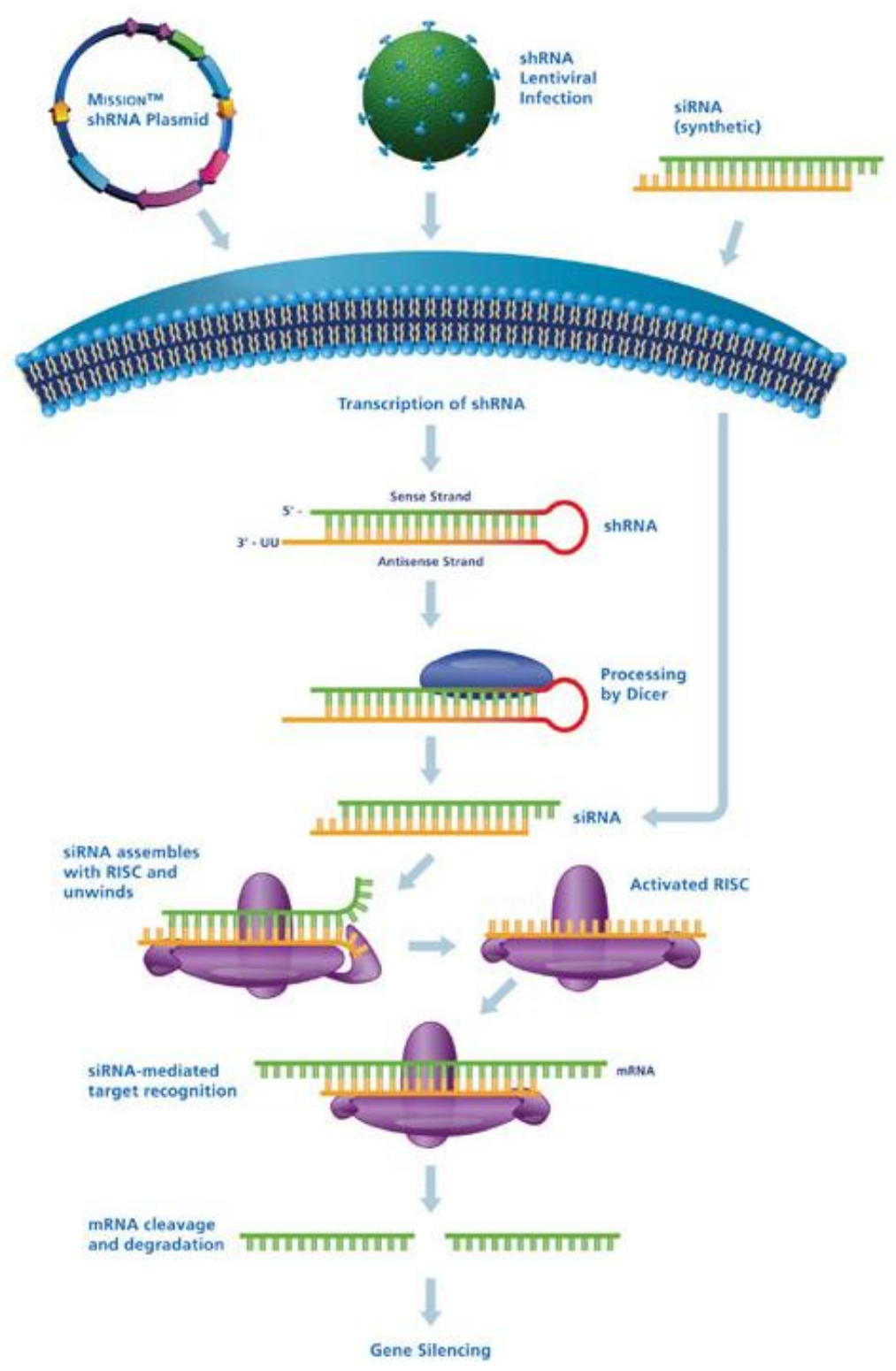

Figura 7 - Silenciamento Gênico mediado por shRNA e siRNA. A transcrição do shRNA no núcleo é clivada pela proteína Dicer gerando siRNA. O siRNA é reconhecido por RISC, que medeia a clivagem do RNAm alvo, promovendo o silenciamento gênico. Fonte: http://www.sigmaaldrich.com/technical-documents/articles/life-scienceinnovations/mission-shrna-library0.html\#R 


\section{OBJETIVOS}

\subsection{Objetivo geral}

Analisar a existência de letalidade sintética causada pela inibição de genes dos diferentes sistemas de reparo de dano ao DNA e diferentes supressores de tumor em células transformadas por HPV.

\subsection{Objetivos específicos}

- Estabelecer bibliotecas de lentivírus que carregam shRNA para genes dos diferentes sistemas de reparo de dano ao DNA e para genes supressores de tumor.

- Utilizar as bibliotecas descritas acima para estudo da existência de letalidade sintética causada pela inibição dos genes alvo em linhagens celulares transformadas por HPV16 e HPV18 (SiHa e HeLa).

- No caso de genes que causem letalidade sintética (identificados conforme descrito acima):

- analisar o envolvimento específico das proteínas E6 ou E7 de HPV16 no processo. Para isto, determinaremos a viabilidade de queratinócitos que expressem apenas uma oncoproteína viral após infecção com lentivírus que codifiquem shRNA para os genes candidatos;

- analisar o efeito de drogas inibidoras dos sistemas de reparo de dano ao DNA ou causadoras de dano ao DNA na viabilidade de linhagens celulares transformadas por HPV16 e HPV18 (SiHa e HeLa);

- analisar o efeito da inibição de genes do sistema de reparo de dano ao DNA na viabilidade de linhagens celulares transformadas por HPV tratadas com drogas causadoras de dano ao DNA. 


\section{METODOLOGIA}

\subsection{Cultura de linhagens celulares}

No presente estudo foram utilizadas linhagens celulares derivadas de carcinomas de colo uterino SiHa (ATCC $\AA$ HTB-35 ${ }^{\mathrm{TM}}$ ) positiva para HPV16, HeLa (ATCC ${ }^{8}$ CCL-2 ${ }^{\text {TM}}$ ) positiva para HPV18 e C33A (ATCC $\circledast$ CRM-HTB-31 ${ }^{\text {TM }}$ ) HPV negativa, foram cultivadas em meio MEM (Minimum Essential Medium Eagle; Invitrogen, CA, USA) suplementado com 10\% SFB (Soro Fetal Bovino; Cultilab, São Paulo, Brasil) (M10). A linhagem epitelial de rim embrionário humano, HEK293T (ATCC ${ }^{8}$ CRL-3216 ${ }^{\mathrm{TM}}$ ), a qual expressa o antígeno $\mathrm{T}$ do símio vírus 40 foi cultivada em meio DMEM (Dulbecco's Modified Eagle's medium; Invitrogen, CA, USA) suplementado com 10\% SFB (D10). Todas as culturas celulares foram mantidas em estufa úmida a $37^{\circ} \mathrm{C}$ com atmosfera de $5 \%$ de $\mathrm{CO}_{2}$.

\subsubsection{Queratinócitos e vetores retrovirais}

Queratinócitos primários humanos (QPH/PHK) de prepúcio de recém-nascidos obtidos comercialmente (\#cc-2507, Lonza, Basel, Switzerland) foram cultivados em meio KSFM (Life Technologies, Inc., Gaithersburg, MD) suplementado com fator de crescimento epidérmico $(5 \mathrm{ng} / \mathrm{mL})$ e extrato de pituitária bovina $(50 \mu \mathrm{g} / \mathrm{mL})$, em estufa úmida, a $37{ }^{\circ} \mathrm{C}$, e com $5 \%$ de $\mathrm{CO}_{2}$. Culturas de $\mathrm{QPH}$ foram transduzidas com vetores retrovirais contendo os genes E6 e/ou E7 de HPV16, ou o mutante amino terminal E6/8S9A10T de HPV16, o qual é defectivo na degradação de p53. Os retrovírus contendo os genes do HPV16 foram gentilmente cedidos pela Dra. Denise A. Galloway (Fred Hutchinson Cancer Research Center, Seattle, USA) e estavam devidamente caracterizados (Demers et al., 1994; Gewin e Galloway, 2001; Helt e Galloway, 2001; Klingelhutz et al., 1996) (Figura 8).

Os plasmídeos recebidos em papel filtro foram crescidos em bactérias competentes DH5- $\alpha$ e inoculados em tubos de cultura contendo meio LB suplementados com o antibiótico de seleção. As bactérias foram incubadas a $37{ }^{\circ} \mathrm{C}$ sob agitação por 24 horas e os plasmídeos forma purificados utilizando o PureYieldTM Plasmid Midiprep System (Promega, Madison, WI), conforme instruções do fabricante. 
Para a obtenção de queratinócitos, que expressam os vetores retrovirais contendo os oncogenes E6 e E7 de HPV16, ou o mutante amino terminal E6/8S9A10T de HPV16, os plasmídeos foram introduzidos em células da linhagem ecotrópica Bosc23 (ATCC® CCL-11270) por eletroporação. Em seguida, as células foram transferidas para placas de Petri de $100 \mathrm{~mm}$ com $7 \mathrm{~mL}$ de meio DMEM (Gibco, Life Technologies) com 10\% SFB (Soro Fetal Bovino; Cultilab, São Paulo, Brasil) (D10) e incubadas a $37{ }^{\circ} \mathrm{C}$ em atmosfera de $5 \%$ de $\mathrm{CO}_{2}$.

Após 48 horas, $5 \mathrm{~mL}$ do sobrenadante das células Bosc23 foram aspirados com uma seringa e acoplada a um filtro de 0,45 $\mu \mathrm{m}$ e gotejado na linhagem anfotrópica de fibroblastos de camundongo Am-12 (Markowitz, 1988), mantidas em cultura em placas de Petri de $100 \mathrm{~mm}$ em uma confluência de 20\%. Em seguida foram adicionados $10 \mu \mathrm{L} / \mathrm{mL}$ de polibreno (Sigma-Aldrich, St. Louis, MO, EUA), um reagente catiônico, o qual minimiza a repulsão eletrostática entre a membrana celular e o envelope viral. Após 8 horas foram adicionados $10 \mathrm{~mL}$ de D10 fresco. Após 48 horas o meio foi substituído por meio D10 com $500 \mu \mathrm{g} / \mathrm{mL}$ Geneticina (G418, GibcoBRL, MD, USA), para seleção das células transduzidas com os plasmídeos pLXSN.

Após uma semana de seleção, momento em que todas as células controle estavam mortas, as células foram mantidas em meio D10 fresco até a formação de colônias. A cultura de QHP foi transduzida com $5 \mathrm{~mL}$ do sobrenadante destas células contendo os retrovírus, que carregavam as sequências gênicas do HPV, conforme descrito acima. Após 45 minutos foram adicionados $5 \mathrm{~mL}$ de KSFM e após 4 horas o meio foi trocado por KSFM fresco. Finalmente os queratinócitos foram selecionados em meio KSFM com G418 (500 $\mu \mathrm{g} / \mathrm{mL})$ por 48 horas, ou até a cultura controle estar morta. Estas linhagem transduzidas com os genes E6 e E7 de HPV16 ou com o mutante amino terminal E6/8S9A10T de HPV16, foram utilizadas em cultura em monocamadas para os experimentos subsequentes. 


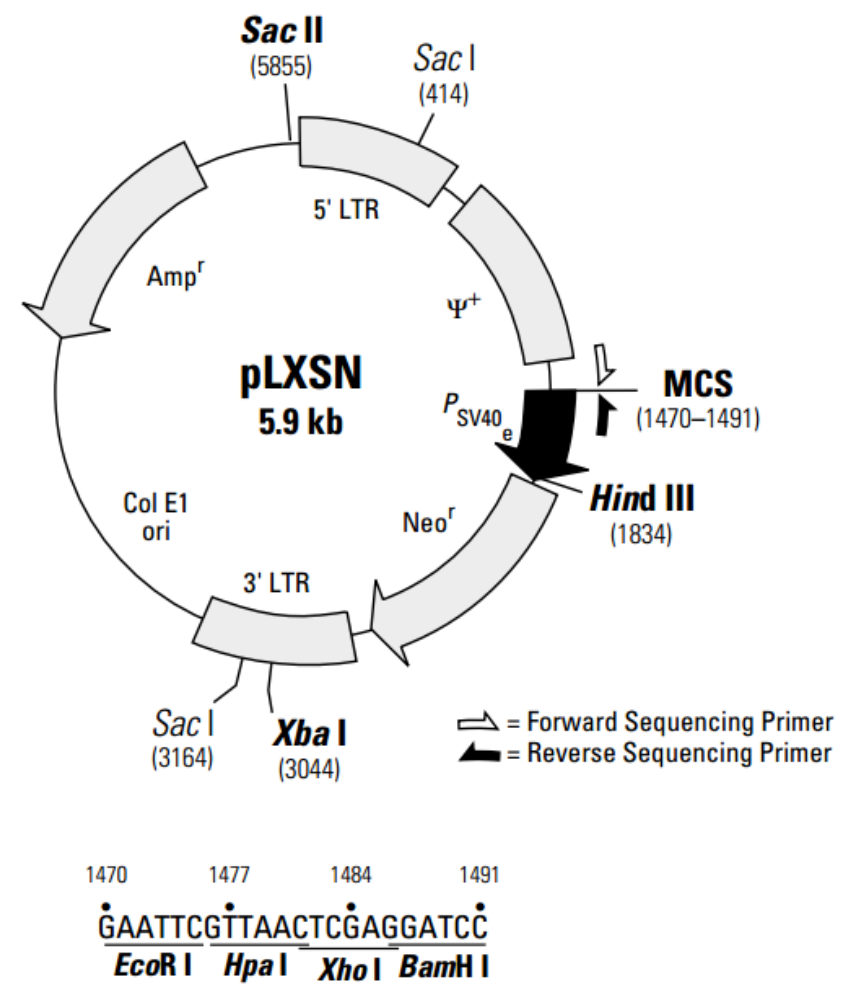

Figura 8 - Mapa esquemático do plasmídeo pLXSN. O plasmídeo pLXSN foi utilizado para a produção de vetores retrovirais que carregavam as sequências codificadoras para as proteínas E6 e/ou E7 de HPV16 clonados no sítio múltiplo de clonagem (MCS). O plasmídeo possui gene de resistência a ampicilina para seleção em bactéria e gene de resistência a geneticina para seleção em células eucariotas transduzidas.

\subsection{Bibliotecas de vetores lentivirais}

Foram utilizadas duas bibliotecas de vetores lentivirais, clonadas em plasmídeo pLKO.1-PURO (Figura 9), que codificam shRNA específicos para genes supressores de tumor e genes envolvidos em diferentes vias de reparo de dano ao DNA. A primeira biblioteca é composta por 443 clones correspondentes a 73 genes supressores de tumor, com uma redundância aproximada de 6 shRNA por gene (MISSION@ shRNA Human Gene Family Set, Tumor Suppressors, SH0511, SigmaAldrich, St. Louis, MO, USA). A segunda biblioteca é composta por 658 clones correspondentes a 116 genes envolvidos em diferentes vias de reparo de dano ao DNA, com redundância de aproximadamente 5 shRNA por gene (MISSION $\Theta$ shRNA Human Gene Family Sets, DNA Repair Pathway, SH1811, Sigma-Aldrich, St. Louis, MO, USA) (Tabela 2). Em anexo se encontra todos os clones de shRNA e as suas respectivas sequências (Anexo I). 


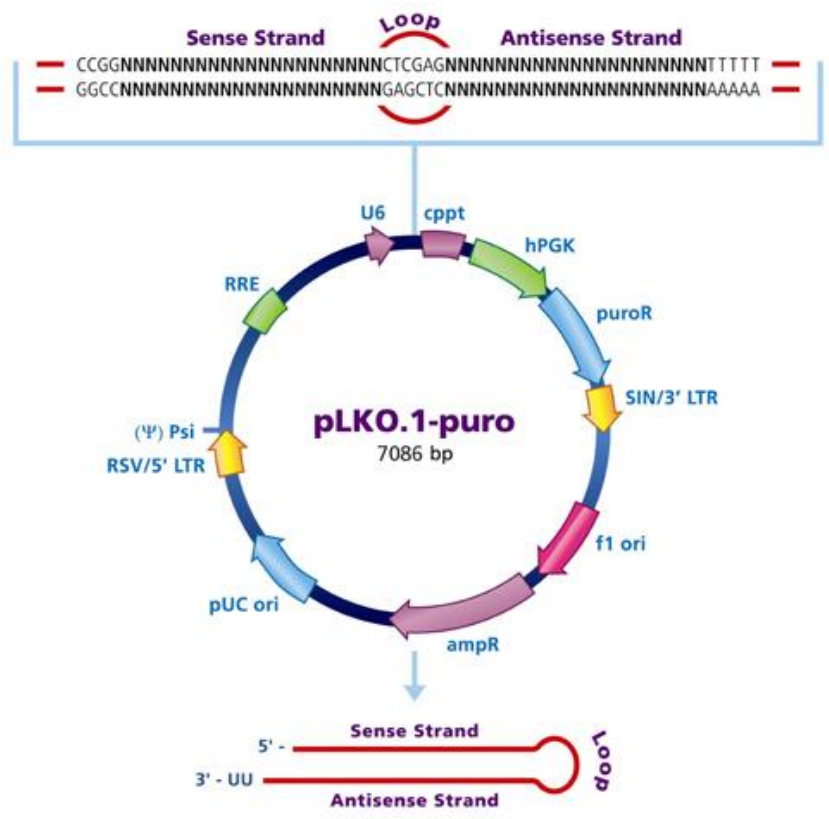

Figura 9 - Mapa esquemático do plasmídeo pLKO.1-puro que carrega as sequências de shRNA. São mostradas as principais regiões funcionais, como por exemplo, o inserto de shRNA, gene de resistência à puromicina (Puro R) para seleção em células eucariotas e gene de resistência a ampicilina (Amp R) para seleção em bactérias.

Tabela 2 - Biblioteca dos vetores lentivirais referente aos 116 genes envolvidos nas vias de Reparo de dano ao DNA e aos 76 genes Supressores de Tumor.

\section{Biblioteca dos Vetores Lentivirais}

\section{DNA Damage Response/Repair}

\begin{tabular}{|c|c|c|c|c|c|c|c|c|c|}
\hline APEX 2 & DCLRE1C & GTF2H2 & PARP3 & RAD51 & TOP2A & APC & DCC & LZTS2 & ST18 \\
\hline ATM & EEF1E1 & GTF2H5 & PARP4 & RAD51AP1 & TOPBP1 & BAX & DLEC1 & MANF & ST5 \\
\hline ATRX & EME1 & H2AFX & PCNA & RAD52 & TP53BP1 & $\mathrm{BCL} 2$ & DMBT1 & MCC & ST7 \\
\hline BLM & EPC2 & HMGB1 & PML & RAD54B & TREX1 & $\mathrm{BCL3}$ & FAT1 & MEN1 & ST7L \\
\hline BRCA1 & ERCC1 & HMGB2 & PNKP & RAD54L & TYMS & $\mathrm{BCR}$ & FAT2 & MLH1 & TAL1 \\
\hline BRCA2 & ERCC5/XPG & HUS1 & POLB & RAD9A & UBE2B & BRCA1 & FAT3 & $\mathrm{MSH} 2$ & TGFBR2 \\
\hline BTG2 & ERCC6/CSB & IGHMBP2 & POLD1 & RBM14 & UHRF1 & BRCA2 & FER & NBL1 & TP53 \\
\hline C11orf30 & FANCA & IHPK3 & POLD3 & RECQL & UPF1 & CCND1 & FLI1 & NF1 & TP63 \\
\hline C1orf124 & FANCC & KCTD13 & POLE & RECQL4 & USP1 & CD82 & FOS & NF2 & TP73 \\
\hline $\mathrm{CCNH}$ & FANCD2 & LIG1 & POLE2 & RECQL5 & UVRAG & $\mathrm{CDC73}$ & FOSL1 & NPRL2 & TSSC1 \\
\hline CDK7 & FANCE & LIG3 & POLG2 & REV3L & VRK3 & $\mathrm{CDH} 1$ & FOSL2 & OVCA2 & TSSC4 \\
\hline CHAF1A & FANCF & MGMT & POLH & RFC1 & WRNIP1 & $\mathrm{CDH} 1$ & GLTSCR1 & PHB & TUSC2 \\
\hline CHAF1B & FANCG & MMS19L & POLI & RFC4 & XAB2 & $\mathrm{CDH} 1$ & GLTSCR2 & PTCH1 & TUSC3 \\
\hline CHEK1 & FANCL & MNAT1 & POLK & RPA1 & XRCC2 & $\mathrm{CDH} 1$ & $\mathrm{HCK}$ & PTEN & TUSC5 \\
\hline CRY1 & FBX018 & MUS81 & POLL & RPA3 & XRCC3 & CDK2AP2 & HIC1 & RAD51 & VHL \\
\hline CRY2 & FLJ35220 & NCOAG & POLN & RRM2B & XRN2 & CDK4 & JUNB & RAD54L & WT1 \\
\hline CSNK1D & FLJ40869 & NONO & PRPF19 & RUVBL2 & & CDKN1A & JUND & RB1 & \\
\hline CSNK1E & GADD45A & NUDT1 & PTTG1 & SFPQ & & CDKN1C & LATS1 & SMAD4 & \\
\hline DCLRE1A & GADD45G & PARP1 & RAD17 & SMC1A & & CDKN2A & LATS2 & ST13 & \\
\hline DCLRE1B & GTF2H1 & PARP2 & RAD18 & TDP1 & & CYLD & LZTS1 & ST14 & \\
\hline
\end{tabular}




\subsection{Produção de estoques bacterianos}

Uma alíquota de cada clone bacteriano foi transferida para $8 \mathrm{~mL}$ de meio $\mathrm{LB}$ suplementado com $75 \mu \mathrm{g} / \mathrm{ml}$ de ampicilina (Sigma-Aldrich, St. Louis, MO, USA) e incubada a $37^{\circ} \mathrm{C}$ por 16 horas, sob agitação de $230 \mathrm{rpm}$. Duas alíquotas de $1 \mathrm{~mL}$ cada foram congeladas em criotubos contendo $10 \%$ de glicerol (Sigma-Aldrich, St. Louis, MO, USA), sendo uma mantida a $-80^{\circ} \mathrm{C}$ e a outra em container de nitrogênio líquido.

\subsection{Purificação do DNA plasmidial}

Para a purificação dos plasmídeos utilizou-se GenElute ${ }^{\text {TM }}$ Plasmid Miniprep Kit (PLN350, Sigma-Aldrich, St. Louis, MO, USA). A purificação foi realizada a partir da recuperação de $5 \mathrm{~mL}$ das bactérias por centrifugação a $12000 \times g$ e posteriormente ressuspendidas em solução para a etapa de lise celular. Após a neutralização e centrifugação das amostras, o sobrenadante foi transferido para uma coluna de purificação proveniente do Kit e lavado para a remoção das impurezas e contaminantes. A eluição foi feita com solução de $10 \mathrm{mM}$ de $\mathrm{TrisHCl}$ e os plasmídeos estocados a $-20{ }^{\circ} \mathrm{C}$ e posteriormente quantificados em espectrofotômetro (NanoDrop 2000, Thermo Scientific, USA) e analisados em gel de agarose $0,8 \%$ (Life Technologies, Inc., Gaithersburg, MD). As amostras que apresentaram baixa concentração de DNA foram crescidos em meio TB (SigmaAldrich, St. Louis, MO, USA) suplementado com $0,8 \%$ de glicerol (Sigma-Aldrich, St. Louis, MO, USA) e $75 \mathrm{\mu g} / \mathrm{ml}$ de ampicilina (Sigma-Aldrich, St. Louis, MO, USA). Os plasmídeos foram purificados, utilizando-se o GenElute ${ }^{\mathrm{TM}}$ Plasmid Midiprep Kit (NA0200, Sigma Aldrich, St. Louis, MO, USA), pelo mesmo princípio descrito acima, porém com uma etapa de recuperação de $50 \mathrm{~mL}$ de bactérias crescidas por $16 \mathrm{~h}$. Possibilitando uma maior recuperação de DNA plasmidial, suficiente para a continuação do trabalho com a grande maioria dos clones de baixo rendimento. 


\subsection{Obtenção de partículas lentivirais e titulação}

A obtenção de partículas lentivirais foi realizada a partir de culturas de células da linhagem HEK293T (ATCC $\AA^{8}$ CRL-3216 ${ }^{\mathrm{TM}}$ ). No primeiro dia 18000 células/poço foram semeadas em placas de 96 poços. No dia seguinte as células presentes em cada poço foram transfectadas com uma mistura composta de $100 \mathrm{ng}$ do vetor correspondente, $1 \mu \mathrm{l}$ do MISSION® Lentiviral Packaging Mix (Sigma-Aldrich, St. Louis, MO, USA), $15 \mu$ l DMEM e 0,6 $\mu$ de FuGENE®6 Transfection Reagent (Promega, Madison, WI) conforme instruções do fabricante. Seguidamente, foram acrescentadas de $100 \mu \mathrm{l}$ de meio DMEM suplementado com $10 \%$ de soro fetal bovino. Após $24 \mathrm{~h}$ os meios foram trocados por DMEM suplementado com $10 \%$ de soro fetal bovino. Os sobrenadantes contendo as partículas virais foram coletados 48 e $72 \mathrm{~h}$ após a transfecção, totalizando $200 \mu \mathrm{l}$ que foram estocados em freezer -80 ${ }^{\circ} \mathrm{C}$ e posteriormente foram titulados utilizando-se HIV-1 p24 Antigen ELISA Kit (Zeptometrix, Buffalo, NY, USA). A leitura da absorbância foi realizada em espectrofotômetro no comprimento de onda de 450nm, conforme indicações do fabricante. Para obtenção de um maior volume lentiviral, $10^{6}$ células da linhagem HEK293T, semeadas em placa de $100 \mathrm{~mm}$, foram transfectadas com uma mistura composta de 2,6 $\mu \mathrm{g}$ do plasmídeo de interesse, $16 \mu \mathrm{l}$ de FuGENE®6, $182 \mu \mathrm{l}$ de DMEM e $26 \mu$ do MISSION $\circledast$ Lentiviral Packaging Mix. Foram recuperados $20 \mathrm{~mL}$ de sobrenadante contendo as partículas virais, os quais foram estocados e titulados conforme descrito acima.

\subsection{Transdução de linhagens celulares e viabilidade celular}

As linhagens tumorais HeLa e SiHa foram semeadas em placas de 96 poços (2500 células/poço). No dia seguinte, as células foram infectadas em triplicata com $50 \mu \mathrm{l}$ dos estoques lentivirais ( $\mathrm{MOI} 10$ ) na presença de $10 \mu \mathrm{g} / \mathrm{ml}$ de polibreno (Sigma-Aldrich, St. Louis, MO, USA). As placas foram centrifugadas a $1180 \times \mathrm{g}$ por 22 minutos e o meio de cultura trocado 24 horas após a infecção. Depois de 120 horas de tratamento foram acrescentados $10 \mu \mathrm{L}$ de resazurina (Alamar Blue, Invitrogen, Carlsbad, CA, USA), a qual é uma substância de cor azul, que é reduzida na presença de células viáveis à resofurina, substância de coloração vermelha. Após a adição de Alamar Blue, as células foram incubadas em estufa úmida a $37^{\circ} \mathrm{C} \mathrm{com}$ 
atmosfera de $5 \%$ de $\mathrm{CO}_{2}$ por mais 4 horas. Após este período a redução do Alamar Blue foi monitorada em espectrofotômetro mediante medição da absorbância a 570 (cor azul) e $600 \mathrm{~nm}$ (cor vermelhar), segundo as instruções do fabricante. Os clones que apresentaram redução maior ou igual a $30 \%$ foram consideradas candidatos para analisar de forma detalhada se estão envolvidos no efeito de letalidade sintética com algum gene alterado das linhagens tumorais. Estes candidatos selecionados a partir da redução da viabilidade das linhagens tumorais foram então validados em culturas de QHP utilizando-se da mesma metodologia descrita acima.

\subsubsection{Transdução das linhagens celulares para o silenciamento dos genes de interesse}

As linhagens de QHP normais ou transduzidas com vetores retrovirais contendo os genes E6 e/ou E7 de HPV16, assim como as linhagens tumorais HeLa e SiHa foram semeadas em placas de $100 \mathrm{~mm}$ ( $1 \times 10^{6}$ células/placa) e infectadas com os estoques lentivirais na presença de $10 \mu \mathrm{L} / \mathrm{mL}$ Polibreno (Sigma-Aldrich, St. Louis, MO, USA). Após 12 horas o meio foi substituído por meio de cultura M10 fresco. Passadas 48 horas da transdução foi realizada a seleção das células com 2 $\mu \mathrm{g} / \mathrm{mL}$ de puromicina (Puromycin Dihydrochloride Gibco®, Life Technologies). As linhagens celulares foram mantidas em de estufa de $\mathrm{CO}_{2}$ a $37^{\circ} \mathrm{C}$ por 48 horas, ou até as culturas controle estarem mortas. Em seguida, as células selecionadas foram utilizadas para os ensaios de viabilidade celular, como descrito acima, e para os experimentos subsequentes.

\subsection{Ensaio clonogênico}

Células tumorais HeLa e $\mathrm{SiHa}$ transduzidas com os vetores lentivirais para o silenciamento dos genes ATM, CHEK2, BRCA1 e HMGB1 foram semeadas em triplicatas em placas de 6 poços (100 células/poço). As células foram cultivadas em meio MEM suplementados com $10 \%$ de SFB por 14 dias em estufa úmida a $37^{\circ} \mathrm{C}$ com atmosfera de $5 \%$ de $\mathrm{CO}_{2}$. Após este período as colônias foram fixadas com solução de etanol 70\% (Merck Millipore, Darmstadt, Germany) e corados com 0,5\% de cristal violeta (Fisher, Waltham, MA) em solução de etanol $10 \%$. 


\subsection{Ensaio clonogênico em Soft ágar}

Para análise do crescimento independente de ancoragem 500 células tumorais HeLa e SiHa transduzidas com os vetores lentivirais para o silenciamento dos genes ATM, CHEK2, BRCA1 e HMGB1 foram suspensas em $500 \mu \mathrm{L}$ de M10 com $0,6 \%$ de agarose e semeadas numa placa de 24 poços com $1 \mathrm{ml}$ de agarose a $1 \%$ e o topo coberta com meio M10. O meio de cultura foi substituído a cada 72 horas e após 30 dias as colônias foram coradas com MTT (3-(4,5-dimethylthiazol-2yl)-2,5-diphenyltetrazolium bromide) e contadas. Todos os experimentos foram realizados pelo menos três vezes independentes e em triplicata.

\subsection{Curva de crescimento}

Culturas de QHP e das linhagens tumorais HeLa e SiHa silenciadas para os genes ATM, CHEK2, BRCA1 e HMGB1 foram semeadas em placas de 24 poços (1000 células por poço) e cultivadas de 1 a 8 dias em estufa úmida a $37^{\circ} \mathrm{C}$ com atmosfera de $5 \%$ de $\mathrm{CO}_{2}$. A proliferação celular foi avaliada do primeiro ao oitavo dia, pela contagem celular em triplicata, utilizando-se o hemocitômetro.

\subsection{Ensaio com fármacos}

Culturas de QPH expressando os genes E6 e/ou E7 de HPV16, ou E6 de HPV16 silenciada para o gene E6AP, ou o mutante amino terminal E6/8S9A10T de HPV16, assim como as linhagens tumorais HeLa, SiHa e C33A foram semeadas em placas de 96 poços (5000 células por poço). No dia seguinte, as células foram tratadas com 2 mM de Cafeína (1,3,7-Trimethylxanthine) (Sigma-Aldrich, St. Louis, MO, USA), a qual inibe a atividade catalítica de ATM e ATR, ou com $10 \mu \mathrm{M}$ de KU55933 (2-(4-Morpholinyl)-6-(1-thianthrenyl)-4H-Pyran-4-one) (Sigma-Aldrich, St. Louis, MO, USA), um inibidor competitivo específico de ATM, ou com $100 \mu \mathrm{M}$ de inibidor de Chek2 II hidratado (2-(4-(4-Chlorophenoxy)phenyl)-1H-benzimidazole-5carboxamide hydrate) (Sigma-Aldrich, St. Louis, MO, USA), um inibidor específico de Chek2. As células tratadas com estes inibidores foram mantidas em estufa por 72 horas e sua viabilidade avaliada pela redução do Alamar Blue, como já descrito acima. 


\subsubsection{Ensaio com fármacos e drogas indutoras de dano ao DNA}

Culturas de QPH expressando os genes E6 e/ou E7 de HPV16, ou E6 de HPV16 silenciada para o gene E6AP, ou o mutante amino terminal E6/8S9A10T de HPV16, assim como as linhagens tumorais HeLa, SiHa e C33A foram semeadas em placas de 96 poços (5000 células por poço). Após 24 horas as células foram tratadas com $1 \mu \mathrm{M}$ de Doxorrubicina (Sigma-Aldrich, St. Louis, MO, USA) e/ou $1 \mu \mathrm{M}$ de Cisplatina (Sigma-Aldrich, St. Louis, MO, USA). Estes tratamentos também foram combinados com os fármacos inibidores de ATM e de CHEK2, conforme descrito acima, e a viabilidade avaliada pelo método de Alamar Blue.

\subsection{Análise da expressão de proteínas}

A extração de proteínas das linhagens analisadas foi realizada mediante lise celular e posterior separação da fração proteica. Para isto, 500-700 $\mu \mathrm{l}$ de solução de lise (150 mM NaCl, $50 \mathrm{mM}$ Tris-HCl pH 7,5, 0,5\% NP40, 0,1 mM EDTA) e inibidores de proteases 20X (Complete Mini, Roche) foram adicionados a cada placa de células e foram coletadas mediante o uso de um cell scraper e transferidas a um tubo Eppendorf de 1,5 mL. Em seguida, as células foram incubadas no gelo por 15 minutos e centrifugadas $14.000 \mathrm{rpm}$ à $4{ }^{\circ} \mathrm{C}$, durante 20 minutos. Por fim, o sobrenadante foi transferido para um novo tubo e as amostras estocadas a $-70{ }^{\circ} \mathrm{C}$. A concentração proteica foi determinada pelo método de Bradford.

\subsubsection{Quantificação de proteínas}

Os extratos proteicos foram quantificados pelo método de Bradford. Foi preparada uma curva padrão a partir de soluções de albumina do soro bovino (BSA) (Sigma-Aldrich, St. Louis, MO, USA) de concentrações conhecidas: $5 \mathrm{mg} / \mathrm{mL}, 2,5$ $\mathrm{mg} / \mathrm{mL}, 1 \mathrm{mg} / \mathrm{mL}$ e $0,5 \mathrm{mg} / \mathrm{mL}$. Foram distribuídos $200 \mu \mathrm{L} /$ poço da solução de Bradford (Bio-Rad) em placas de 96 poços e foi adicionado $1 \mu \mathrm{L}$ das soluções de BSA, de concentrações conhecidas, e dos extratos proteicos de interesse. A placa foi incubada por 5 minutos e a absorbância medida a $595 \mathrm{~nm}$ em espectrofotômetro. 
Os dados obtidos foram analisados no programa Excel do Pacote Office, permitindo assim o cálculo da concentração da amostra.

\subsubsection{Western blot}

As amostras de proteínas foram submetidas a eletroforese em gel de SDSpoliacrilamida $10 \%, 12 \%$ ou gradiente de $4-12 \%$ utilizando o sistema mini-Protean II Cell (Bio-Rad). Para o preparo de $5 \mathrm{~mL}$ do gel de separação de $10 \%$ de acrilamida foram utilizados: 1,97 mL de $\mathrm{H}_{2} \mathrm{O}$ Milli-Q, 1,25 mL de lower buffer (Tris- $\mathrm{HCl} 1,5 \mathrm{M} \mathrm{pH}$ 8,8, SDS 0,4\%), 1,65 mL de acrilamida-bisacrilamida (29:1) 30\%, $100 \mu \mathrm{L}$ de persulfato de amônio 10\% (APS) e 1,5 $\mu \mathrm{L}$ de TEMED (Sigma-Aldrich). Para a preparação do gel de gradiente foi preparada um gel de $4 \%$ e um de $12 \%$ de acrilamida, os quais foram pipetados com o auxílio de uma pipeta sorológica, do menos para o mais concentrado, para que o gradiente se estabelecesse na pipeta. Depois foram dispensados levemente no sistema mini-Protean II. Na porção superior do gel de separação foi aplicado um gel de stacking 4\% composto por: 3,6 mL de $\mathrm{H}_{2} \mathrm{O}$ Milli-Q, $625 \mu \mathrm{L}$ de upper buffer (Tris-HCl 1,0 M pH 6,8, SDS 0,4\%), $665 \mu \mathrm{l}$ de acrilamida-bisacrilamida (29:1) 30\%, $100 \mu \mathrm{L}$ de APS 10\% e 1,5 $\mu \mathrm{L}$ de TEMED para um volume final de $5 \mathrm{~mL}$.

As amostras foram preparadas colocando-se $30 \mu \mathrm{g}$ de proteína em tampão de amostra v/v (Tris-HCl 240 mM pH 6,8, SDS 0,8\%, $\beta$-mercaptoetanol 200 mM, glicerol $40 \%$ e azul de bromofenol 0,02\%), desnaturadas a $95{ }^{\circ} \mathrm{C}$ durante 10 minutos e mantidas no gelo por 5 minutos. Em seguida, as amostras foram aplicadas no gel e submetidas a eletroforese a 80-120 V em tampão de corrida (glicina $192 \mathrm{mM}$, Tris 25mM, SDS 0,1\%). Finalmente as amostras foram eletrotransferidas (Mini Trans-Blot Cell, BIO-RAD) para uma membrana de polivinilidene difluoreto (PVDF) (Hybond-P, Amersham Pharmacia Biotech) a 250 mA em tampão de transferência (glicina 200 $\mathrm{mM}$, Tris $25 \mathrm{mM}$, metanol 20\% v/v (Merck)) durante $1 \mathrm{~h}$ a $4{ }^{\circ} \mathrm{C}$. A transferência foi conferida através da coloração com Ponceau (Sigma-Aldrich, St. Louis, MO, USA) $0,1 \%$ em ácido acético $1 \%$. As membranas foram analisadas utilizando anticorpos específicos para as proteínas: 
Tabela 3 - Lista de anticorpos utilizados e respectivas concentrações.

\begin{tabular}{|l|l|l|l|c}
\multicolumn{1}{c|}{$\begin{array}{c}\text { Proteína } \\
\text { Reconhecida }\end{array}$} & \multicolumn{1}{|c|}{$\begin{array}{c}\text { Marca do } \\
\text { Anticorpo }\end{array}$} & \multicolumn{1}{c|}{$\begin{array}{c}\text { Número de } \\
\text { Catálogo }\end{array}$} & \multicolumn{1}{c}{ Origem } & Concentração \\
\hline ATM & Abcam & Ab78 & Camundongo & $1 / 1000$ \\
ATM (phospho S1981) & Abcam & Ab81292 & Coelho & $1 / 1000$ \\
BRCA1 & Abcam & Ab16781 & Camundongo & $1 / 1000$ \\
Caspase 3 Ativa & Abcam & Ab13847 & Coelho & $1 / 1000$ \\
CHEK2 & Abcam & Ab47433 & Coelho & $1 / 1000$ \\
CHEK2 (phospho T68) & Abcam & Ab32148 & Coelho & $1 / 1000$ \\
Gamma H2AX & Abcam & Ab22551 & Camundongo & $1 / 1000$ \\
HMGB1 & Abcam & Coelho & $1 / 20000$ \\
Tubulina & Santa Cruz & SC-25259 & Camundongo & $1 / 10000$ \\
UBE3A & Abcam & Ab126765 & Coelho & $1 / 500$ \\
\hline
\end{tabular}

Inicialmente, as membranas foram bloqueadas com PBS-T (137 mM NaCl, 2,7 $\mathrm{mM} \mathrm{KCl}, 10 \mathrm{mM} \mathrm{Na}_{2} \mathrm{HPO}_{4}, 2 \mathrm{mM} \mathrm{KH}_{2} \mathrm{PO}_{4}$, pH 7,4, Tween-20 0,05\%) contendo 5\% de leite em pó durante 1 hora. Em seguida, as membranas foram lavadas rapidamente em PBS-T e incubadas por 24 horas na presença de um dos anticorpos específicos descritos acima. Os anticorpos foram diluídos em PBS-T com 1\% de leite nas concentrações sugeridas pelo fabricante. Posteriormente, as membranas foram lavadas (4 vezes) com PBS-T durante 5 minutos e incubadas durante 1 hora na presença de anticorpos secundários anti-IgG de camundongo produzido em cabra (111-035-003, Jackson) ou anti-coelho (115-035-003, Jackson) na diluição de 1:5000 em PBS-T contendo 1\% leite. Por fim, as membranas foram lavadas durante 4 vezes de 5 minutos com PBS-T e reveladas utilizando o Kit Amersham ECL Prime Western Blotting Detection (GE Healthcare life Sciences, USA).

\subsection{Análises estatísticas}

As análises estatísticas e a elaboração dos gráficos foram realizadas utilizando-se o software GraphPad Prism V.6 (GraphPad Software Inc.) e aplicando o Teste T Student não paramétrico. Sendo considerados os resultados significativos $\geq 0,05$. 


\section{RESULTADOS}

\subsection{Estoque bacteriano e purificação}

Foi estabelecido estoques dos 1101 clones bacterianos correspondentes as bibliotecas de Genes Supressores de Tumor e Genes envolvidos em diferentes vias de reparo de dano ao DNA. Durante a etapa de purificação alguns clones apresentaram diferenças significativas nos rendimentos de DNA plasmidial e foram crescidos em meio TB (Sigma-Aldrich, St. Louis, MO, USA) suplementado com 0,8\% de glicerol e $75 \mu \mathrm{g} / \mathrm{ml}$ de ampicilina e purificados por Midprep, (Figura 10). Todos os plasmídeos foram confirmados em gel de agarose $0,8 \%$ e quantificados por Nanodrop, o que nos proporcionou concentrações de DNA plasmidial suficientes para os experimentos subsequentes.
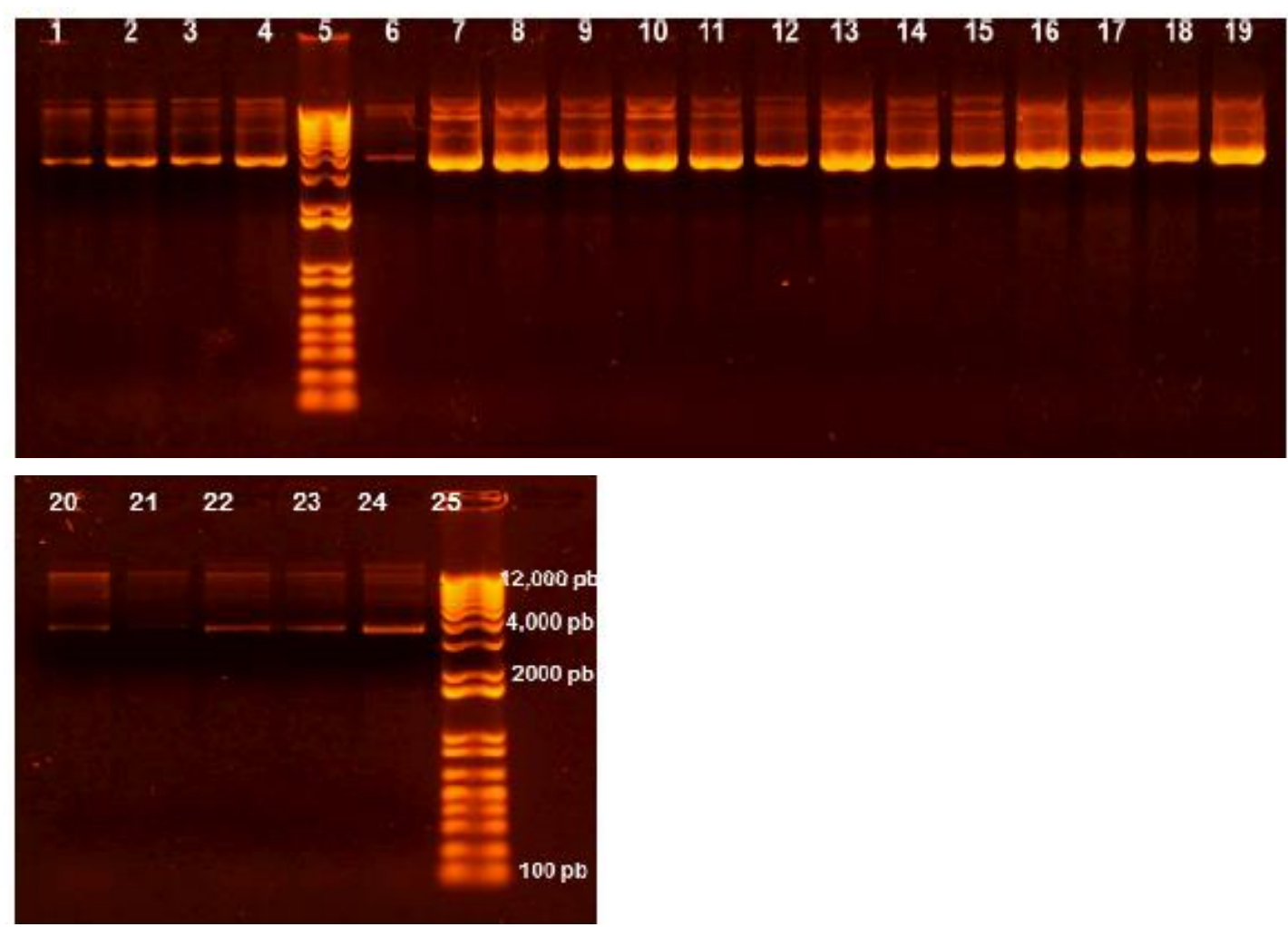

Figura 10 - Eletroforese em gel de agarose 0,8\% dos produtos de extração dos vetores pLKO.1 puro com o inserto de shRNA dos diferentes clones da biblioteca de genes Supressores de Tumor e de Reparo ao Dano de DNA. Evidenciando os diferentes rendimentos encontrados entre eles: (1 a 4) Clones do gene NPRL2. (6 a 10) Clones do gene ATM. (11 a 15) Clones do gene ATR. (16 a 19) Clones do gene CHEK1. (20 a 24) Clones do gene de CHEK2. (5 e 25) Marcadores de peso molecular de $1 \mathrm{~Kb}$. 


\subsection{Produção de lentivírus e titulação}

Foram produzidos lentivírus correspondentes aos 1101 clones presentes nas duas bibliotecas, os quais foram estocados em freezer $-80 \stackrel{\circ}{\circ}$. As partículas virais dos 1101 clones de lentivírus produzidos foram tituladas pela detecção da proteína p24 do capsídeo viral pelo método de ELISA (Enzyme Linked Immuno Sorbent Assay). Nesta etapa tivemos que adaptar o protocolo com uma diluição do sobrenadante lentiviral (1:200), pois conforme indicações do fabricante seriam necessários $180 \mu \mathrm{l}$ de amostra, o que esgotaria o nosso estoque. A partir da curva padrão obtida pela detecção da proteína p24 de HIV-1 em diferentes diluições (Figura 11), foi calculado o título viral para os 1101 sobrenadantes lentivirais, conforme representado para 92 clones na Tabela 3. Os títulos obtidos foram suficientes para transduzir a maior parte de QHP e as diferentes linhagens derivadas de carcinomas de colo uterino com um MOI igual a 10. As células foram infectadas em triplicata com $50 \mu \mathrm{l}$ dos estoques lentivirais na presença de $10 \mu \mathrm{g} / \mathrm{ml}$ de polibreno.

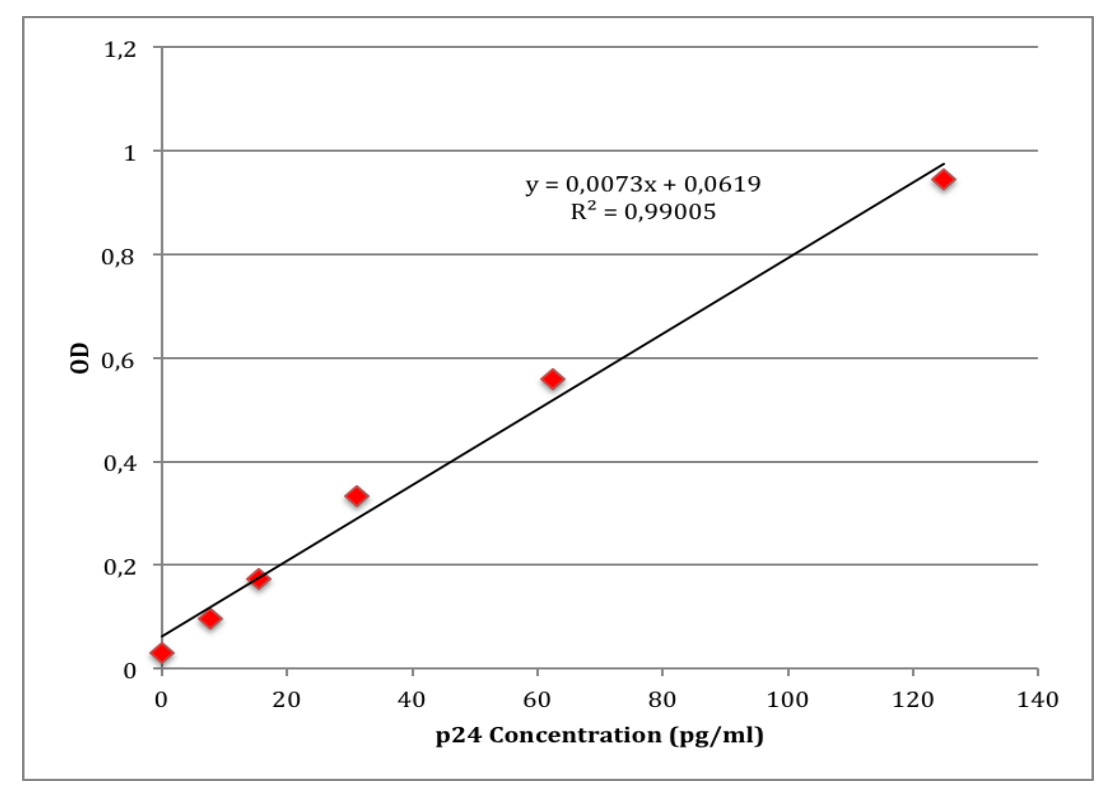

Figura 11 - Curva Padrão para Determinação da Concentração de p24. A curva padrão foi obtida pela detecção da proteína p24 de HIV-1 em diferentes diluições utilizando HIV-1 p24 Antigen ELISA Kit (Zeptometrix). 
Tabela 4 - Concentração viral obtida a partir dos sobrenadantes lentivirais.

\begin{tabular}{|c|c|c|c|c|c|c|c|c|c|c|}
\hline Dilution Factor & OD of titer well & p24 (pg/ml) & Titer (TU/ul) & Position & GENE & OD of titer well & p24 (pg/ml) & Titer (TU/ul) & Position & GENE \\
\hline \multirow[t]{47}{*}{200} & 1,133203 & 126,72 & $2,53 E+03$ & A1 & LZTS1 & 1,101717 & 122,40 & $2,45 E+03$ & D12 & RAD54L \\
\hline & 0,805236 & 81,75 & $1,63 \mathrm{E}+03$ & $\mathrm{~A} 2$ & LZTS1 & 0,8268491 & 84,71 & $1,69 \mathrm{E}+03$ & E1 & RAD54L \\
\hline & 0,8143953 & 83,00 & $1,66 \mathrm{E}+03$ & $\mathrm{~A} 3$ & LZTS1 & 0,6832249 & 65,02 & $1,30 \mathrm{E}+03$ & E2 & RAD54L \\
\hline & 1,447564 & 169,82 & $3,40 E+03$ & A4 & LZTS1 & 0,4934742 & 39,00 & $7,80 \mathrm{E}+02$ & E3 & CHEK1 \\
\hline & 1,440724 & 168,88 & $3,38 \mathrm{E}+03$ & A5 & ST14 & 1,322821 & 152,71 & $3,05 E+03$ & E4 & CHEK1 \\
\hline & 1,493221 & 176,08 & $3,52 E+03$ & A6 & ST14 & 0,6924073 & 66,28 & $1,33 E+03$ & E5 & CHEK1 \\
\hline & 1,47719 & 173,88 & $3,48 E+03$ & A7 & WT1 & 0,6660067 & 62,66 & $1,25 E+03$ & E6 & CHEK1 \\
\hline & 1,464158 & 172,09 & $3,44 \mathrm{E}+03$ & A8 & WT1 & 0,5370243 & 44,98 & $9,00 \mathrm{E}+02$ & E7 & CHEK1 \\
\hline & 1,116892 & 124,48 & $2,49 \mathrm{E}+03$ & A9 & WT1 & 0,986824 & 106,65 & $2,13 E+03$ & E8 & CDK7 \\
\hline & 1,170086 & 131,77 & $2,64 \mathrm{E}+03$ & A10 & WT1 & 1,347751 & 156,13 & $3,12 E+03$ & E9 & CDK7 \\
\hline & 1,806262 & 219,00 & $4,38 \mathrm{E}+03$ & A11 & WT1 & 0,7977185 & 80,72 & $1,61 \mathrm{E}+03$ & $\mathrm{E} 10$ & CDK7 \\
\hline & 1,341149 & 155,23 & $3,10 \mathrm{E}+03$ & A12 & WT1 & 0,9727786 & 104,72 & $2,09 \mathrm{E}+03$ & E11 & CDK7 \\
\hline & 1,47384 & 173,42 & $3,47 \mathrm{E}+03$ & B1 & WT1 & 1,038622 & 113,75 & $2,27 \mathrm{E}+03$ & E12 & CDK7 \\
\hline & 0,9629373 & 103,37 & $2,07 E+03$ & B2 & WT1 & 0,3745598 & 22,70 & $4,54 \mathrm{E}+02$ & F1 & CSNK1D \\
\hline & 0,7026368 & 67,68 & $1,35 \mathrm{E}+03$ & B3 & CDC73 & 0,5955256 & 53,00 & $1,06 \mathrm{E}+03$ & $\mathrm{~F} 2$ & CSNK1D \\
\hline & 1,093691 & 121,30 & $2,43 E+03$ & B4 & CDC73 & 0,4783161 & 36,93 & $7,39 \mathrm{E}+02$ & F3 & CSNK1D \\
\hline & 0,7190757 & 69,94 & $1,40 \mathrm{E}+03$ & B5 & $\mathrm{CDC73}$ & 0,5153609 & 42,00 & $8,40 \mathrm{E}+02$ & F4 & CSNK1D \\
\hline & 0,8015033 & 81,24 & $1,62 \mathrm{E}+03$ & B6 & CDC73 & 0,5213248 & 42,82 & $8,56 \mathrm{E}+02$ & F5 & CSNK1D \\
\hline & 1,654477 & 198,19 & $3,96 \mathrm{E}+03$ & B7 & $\mathrm{CDC73}$ & 0,5977657 & 53,30 & $1,07 \mathrm{E}+03$ & F6 & CSNK1E \\
\hline & 1,853809 & 225,52 & $4,51 \mathrm{E}+03$ & B8 & LZTS2 & 0,6942149 & 66,53 & $1,33 \mathrm{E}+03$ & F7 & CSNK1E \\
\hline & 1,219639 & 138,57 & $2,77 \mathrm{E}+03$ & B9 & LZTS2 & 0,7317988 & 71,68 & $1,43 E+03$ & F8 & CSNK1E \\
\hline & 0,6466935 & 60,01 & $1,20 \mathrm{E}+03$ & B10 & LZTS2 & 1,07829 & 119,19 & $2,38 \mathrm{E}+03$ & F9 & CSNK1E \\
\hline & 1,674492 & 200,93 & $4,02 E+03$ & B11 & LZTS2 & 0,9716495 & 104,57 & $2,09 \mathrm{E}+03$ & F10 & CSNK1E \\
\hline & 1,080109 & 119,44 & $2,39 E+03$ & B12 & CCND1 & 0,7916468 & 79,89 & $1,60 \mathrm{E}+03$ & F11 & VRK3 \\
\hline & 0,7649519 & 76,23 & $1,52 \mathrm{E}+03$ & C1 & CCND1 & 0,8102434 & 82,44 & $1,65 \mathrm{E}+03$ & F12 & VRK3 \\
\hline & 1,047466 & 114,96 & $2,30 \mathrm{E}+03$ & $\mathrm{C} 2$ & CCND1 & 0,6218716 & 56,61 & $1,13 \mathrm{E}+03$ & G1 & VRK3 \\
\hline & 0,9055368 & 95,50 & $1,91 \mathrm{E}+03$ & C3 & CCND1 & 0,7738394 & 77,44 & $1,55 \mathrm{E}+03$ & G2 & VRK3 \\
\hline & 0,8427001 & 86,89 & $1,74 \mathrm{E}+03$ & C4 & CCND1 & 0,8969951 & 94,33 & $1,89 \mathrm{E}+03$ & G3 & VRK3 \\
\hline & 0,882041 & 92,28 & $1,85 \mathrm{E}+03$ & C5 & CCND1 & 0,6308265 & 57,84 & $1,16 \mathrm{E}+03$ & G4 & SFPQ \\
\hline & 1,217127 & 138,22 & $2,76 \mathrm{E}+03$ & C6 & CDKN2A & 0,8300577 & 85,15 & $1,70 \mathrm{E}+03$ & G5 & SFPQ \\
\hline & 1,06337 & 117,14 & $2,34 \mathrm{E}+03$ & $\mathrm{C} 7$ & CDKN2A & 0,9806475 & 105,80 & $2,12 E+03$ & G6 & SFPQ \\
\hline & 0,922695 & 97,85 & $1,96 \mathrm{E}+03$ & $\mathrm{C} 8$ & CDKN2A & 0,7636069 & 76,04 & $1,52 \mathrm{E}+03$ & G7 & SFPQ \\
\hline & 0,845351 & 87,25 & $1,74 \mathrm{E}+03$ & C9 & CDKN2A & 1,283683 & 147,35 & $2,95 \mathrm{E}+03$ & G8 & SFPQ \\
\hline & 1,802518 & 218,48 & $4,37 \mathrm{E}+03$ & C10 & CDKN2A & 1,31192 & 151,22 & $3,02 E+03$ & G9 & RAD18 \\
\hline & 0,8501118 & 87,90 & $1,76 \mathrm{E}+03$ & C11 & CDKN2A & 1,107297 & 123,16 & $2,46 \mathrm{E}+03$ & $\mathrm{G} 10$ & RAD18 \\
\hline & 1,022925 & 111,60 & $2,23 E+03$ & $\mathrm{C} 12$ & OVCA2 & 0,8641895 & 89,83 & $1,80 \mathrm{E}+03$ & G11 & RAD18 \\
\hline & 0,8935345 & 93,86 & $1,88 \mathrm{E}+03$ & D1 & OVCA2 & 1,147633 & 128,69 & $2,57 \mathrm{E}+03$ & G12 & RAD18 \\
\hline & 0,9258509 & 98,29 & $1,97 \mathrm{E}+03$ & D2 & OVCA2 & 0,4583952 & 34,19 & $6,84 \mathrm{E}+02$ & $\mathrm{H} 1$ & PCNA \\
\hline & 0,8060669 & 81,86 & $1,64 \mathrm{E}+03$ & D3 & TUSC5 & 0,4105095 & 27,63 & $5,53 \mathrm{E}+02$ & $\mathrm{H} 2$ & PCNA \\
\hline & 0,6827891 & 64,96 & $1,30 \mathrm{E}+03$ & D4 & TUSC5 & 0,675426 & 63,95 & $1,28 \mathrm{E}+03$ & $\mathrm{H} 3$ & PCNA \\
\hline & 0,9982253 & 108,21 & $2,16 \mathrm{E}+03$ & D5 & TUSC5 & 1,075484 & 118,80 & $2,38 \mathrm{E}+03$ & $\mathrm{H} 4$ & PCNA \\
\hline & 0,9971257 & 108,06 & $2,16 \mathrm{E}+03$ & D6 & FAT3 & 0,5879497 & 51,96 & $1,04 \mathrm{E}+03$ & $\mathrm{H} 5$ & PCNA \\
\hline & 0,9180856 & 97,22 & $1,94 \mathrm{E}+03$ & D7 & FAT3 & 1,416213 & 165,52 & $3,31 E+03$ & $\mathrm{H} 6$ & PML \\
\hline & 1,176132 & 132,60 & $2,65 E+03$ & D8 & FAT3 & 0,8661832 & 90,10 & $1,80 \mathrm{E}+03$ & $\mathrm{H} 7$ & PML \\
\hline & 1,085115 & 120,12 & $2,40 E+03$ & D9 & FAT3 & 0,7208855 & 39,58 & $7,92 \mathrm{E}+02$ & $\mathrm{H} 8$ & PML \\
\hline & 0,6415731 & 59,31 & $1,19 \mathrm{E}+03$ & D10 & RAD54L & 0,9743642 & 63,86 & $1,28 E+03$ & $\mathrm{H} 9$ & PML \\
\hline & 0,869725 & 90,59 & $1,81 \mathrm{E}+03$ & D11 & RAD54L & 0,7200826 & 39,50 & $7,90 \mathrm{E}+02$ & $\mathrm{H} 10$ & PML \\
\hline
\end{tabular}




\subsection{Viabilidade celular}

Células HeLa e SiHa transduzidas em triplicatas com os 1101 vetores de shRNA para silenciamento de genes específicos tiveram sua viabilidade avaliada pela redução de Alamar Blue, conforme ilustrado para 92 vetores na Figura 12. Após a finalização da análise da viabilidade de HeLa e SiHa foram identificados 39 clones de shRNA, correspondentes a 22 genes, capazes de reduzir a viabilidade celular das linhagens tumorais simultaneamente em pelo menos 30\% (Figura 13). Em cada análise da viabilidade celular foram utilizadas 12 placas de 96 poços que permitiram um ensaio em triplicata das linhagens tumorais. Esta primeira etapa, utilizando somente células HeLa e SiHa, serviu para selecionarmos aqueles clones que em um primeiro momento foram capazes de diminuir a viabilidade das células tumorais HPV positivas. Muitos destes genes identificados apresentaram mais de um clone de silenciamento capazes de reduzir a viabilidade e a proliferação das células tumorais, dando consistência ao resultado para a validação em queratinócitos humanos primários (QHP). Na segunda etapa, de validação dos resultados em QHP, foram produzidos lentivírus referentes aos 39 clones selecionados, os quais foram titulados e transduzidos em triplicatas nas linhagens tumorais e QHP. Destes, apenas 2 clones para ATM, 3 clones para CHEK2, 3 clones para BRCA1 e 2 clones para HMGB1 foram confirmados ao reduzir a viabilidade das linhagens tumorais HeLa e $\mathrm{SiHa}$, mas sem afetar a viabilidade de QHP (Figura 14).

O gene HMGB1 codifica para proteínas do grupo de alta mobilidade box 1 , as quais são proteínas não-histonas presentes em altas concentrações no núcleo celular na forma hipoacetilada, sendo o preferencial ligante à diferentes tipos dano de DNA (Lanuszewska e Widlak, 2000; Ohndorf et al.,1999; Pasheva et al., 2008). Os genes ATM, CHEK2 e BRCA1 expressam para proteínas envolvidas em uma mesma via de sinalização de danos de quebras de fita dupla ao DNA, o que nos fornece um grande indício que esta via desempenhe um importante papel no processo de viabilidade e proliferação das células transformadas por HPV. 


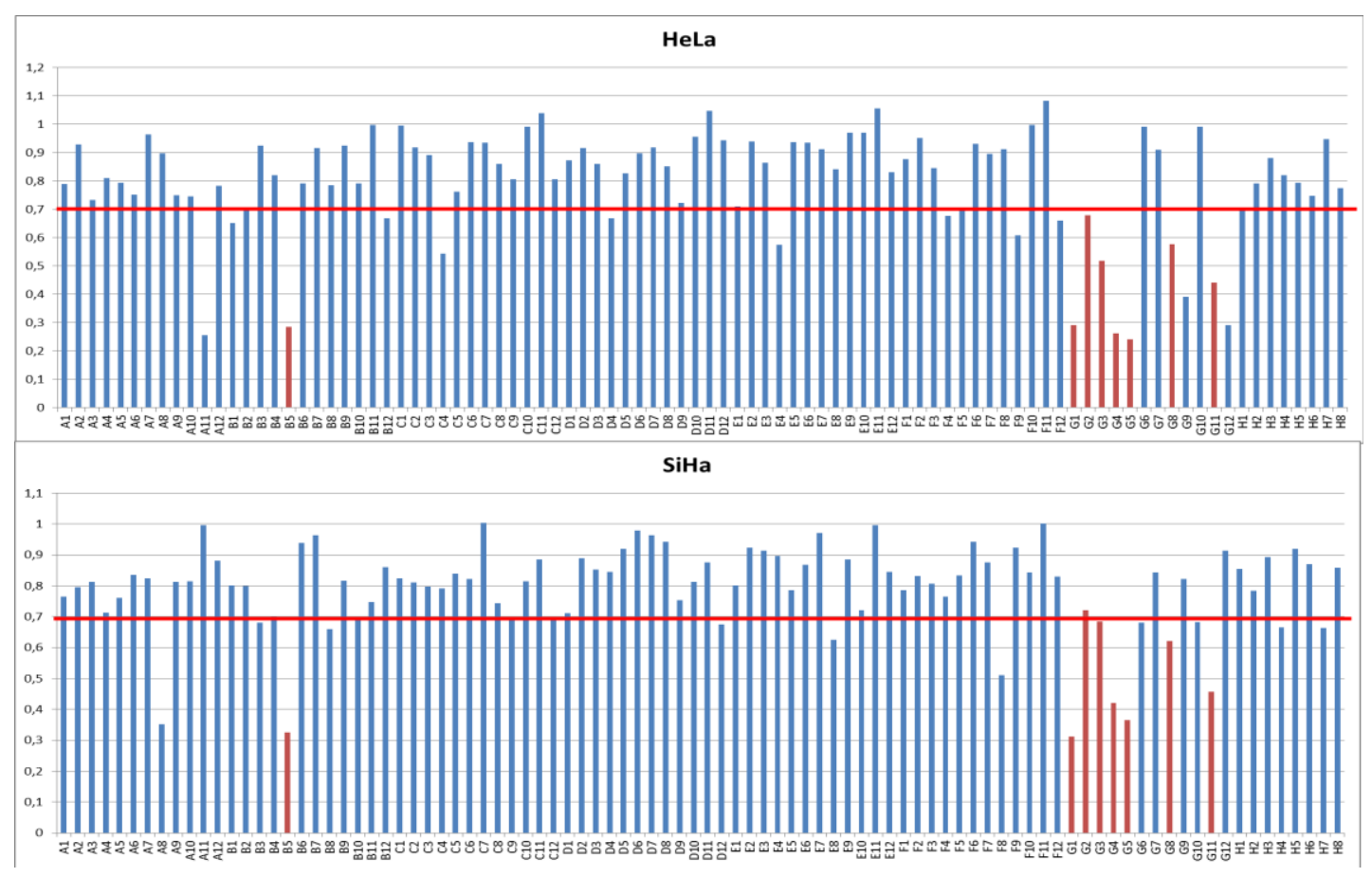

Figura 12 - Análise da viabilidade e proliferação de células HeLa e SiHa após silenciamento de diversos genes. As células foram semeadas em placas de 96 poços (2500 células por poço) e tiveram sua viabilidade celular avaliada pela redução de Alamar Blue. Foram considerados como possíveis candidatos os clones que foram capazes de reduzir a viabilidade de HeLa e SiHa simultaneamente (identificados pelas barras vermelhas), quando comparados ao controle (Células transduzidas com o shRNA Scramble).

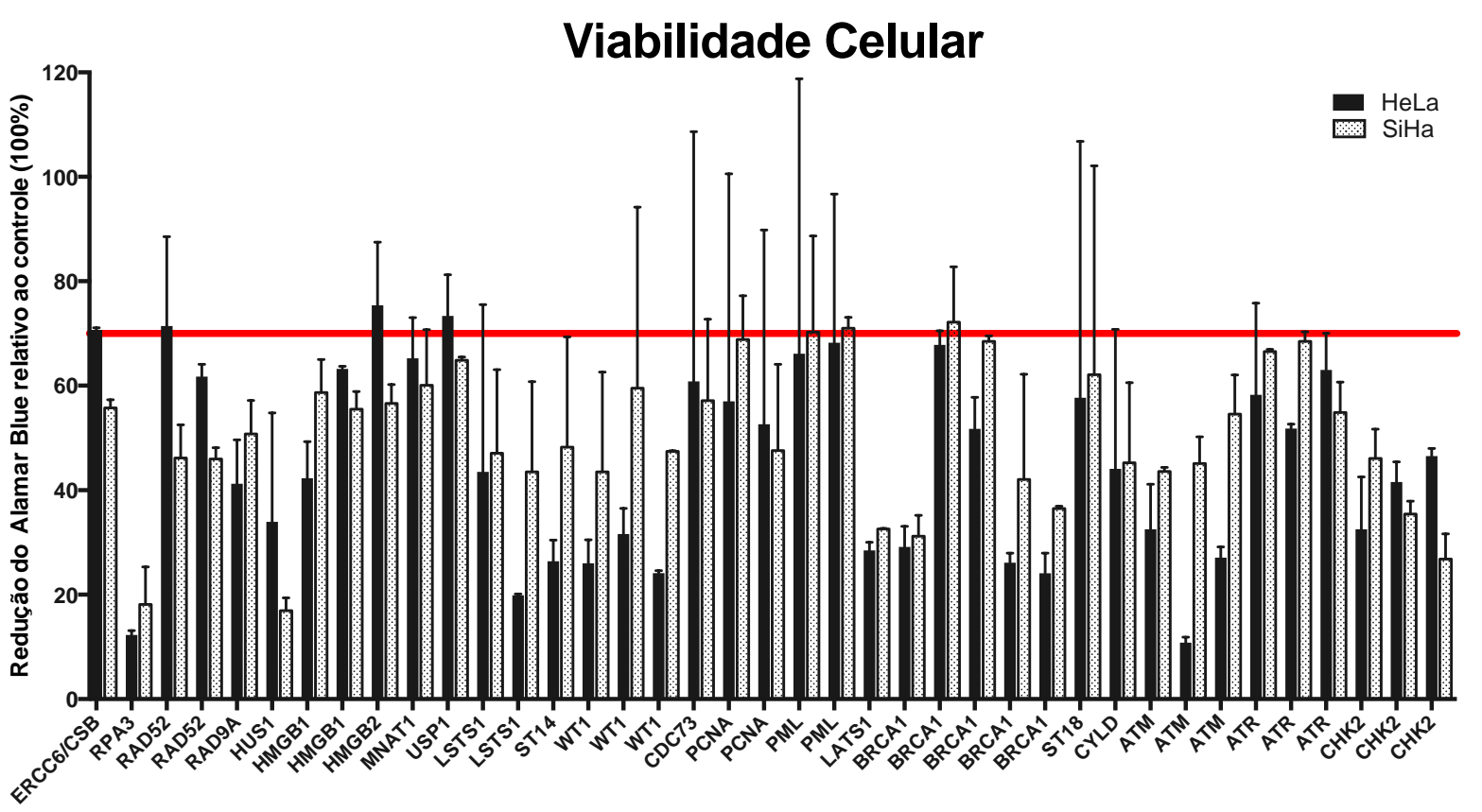

Figura 13 - Identificação dos clones de shRNA capazes de reduzir a viabilidade e a proliferação de HeLa e SiHa. Após a finalização do testes com as duas bibliotecas de vetores lentivirais foram identificados 39 clones de shRNA capazes de reduzir a proliferação e viabilidade das células tumorais em até $30 \%$ quando comparados ao controle (Células transduzidas com o shRNA Scramble). A viabilidade foi determinada pela redução de Alamar Blue. 


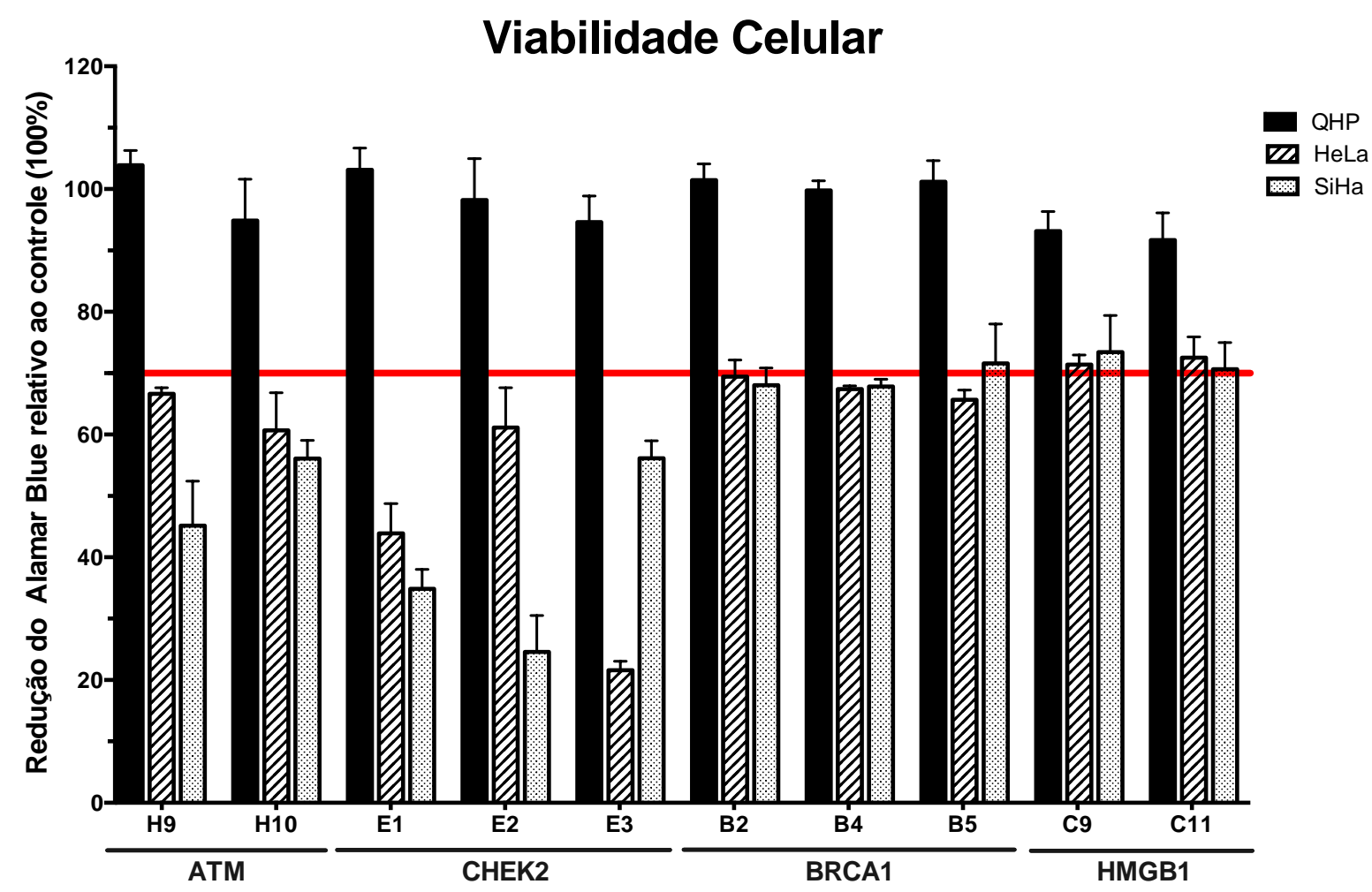

Figura 14 - Validação da viabilidade e proliferação de células QHP, HeLa e SiHa com os 34 possíveis candidatos de shRNA. Após a identificação dos 34 clones capazes de reduzir a viabilidade das células tumorais, estes foram analisados em QHP. As células foram semeadas em placas de 96 poços (2500 células por poço) e após 24 horas foram silenciadas com os diferentes clones lentivirais. Após 120 horas tiveram sua viabilidade avaliada pela redução de Alamar Blue. Destes, somente 10 clones, correspondentes a 4 genes, foram capazes de reduzir a viabilidade de HeLa e SiHa, sem alterar a viabilidade de QHP. (Teste t Student $\mathrm{p}<0,005)$

\subsection{Confirmação do silenciamento gênico}

Os candidatos de shRNA selecionados para se analisar de forma mais detalhada se estão envolvidos no efeito de letalidade sintética com algum gene alterado das linhagens tumorais, tiveram seus silenciamentos confirmados pelos níveis de proteínas detectadas por western blot. Os diferentes clones de ATM, CHEK2 e HMGB1 tiveram uma redução significativa dos níveis de proteínas nas linhagens tumorais HeLa e SiHa e também em QHP, quando comparadas com o controle Scramble (Figura 15). 

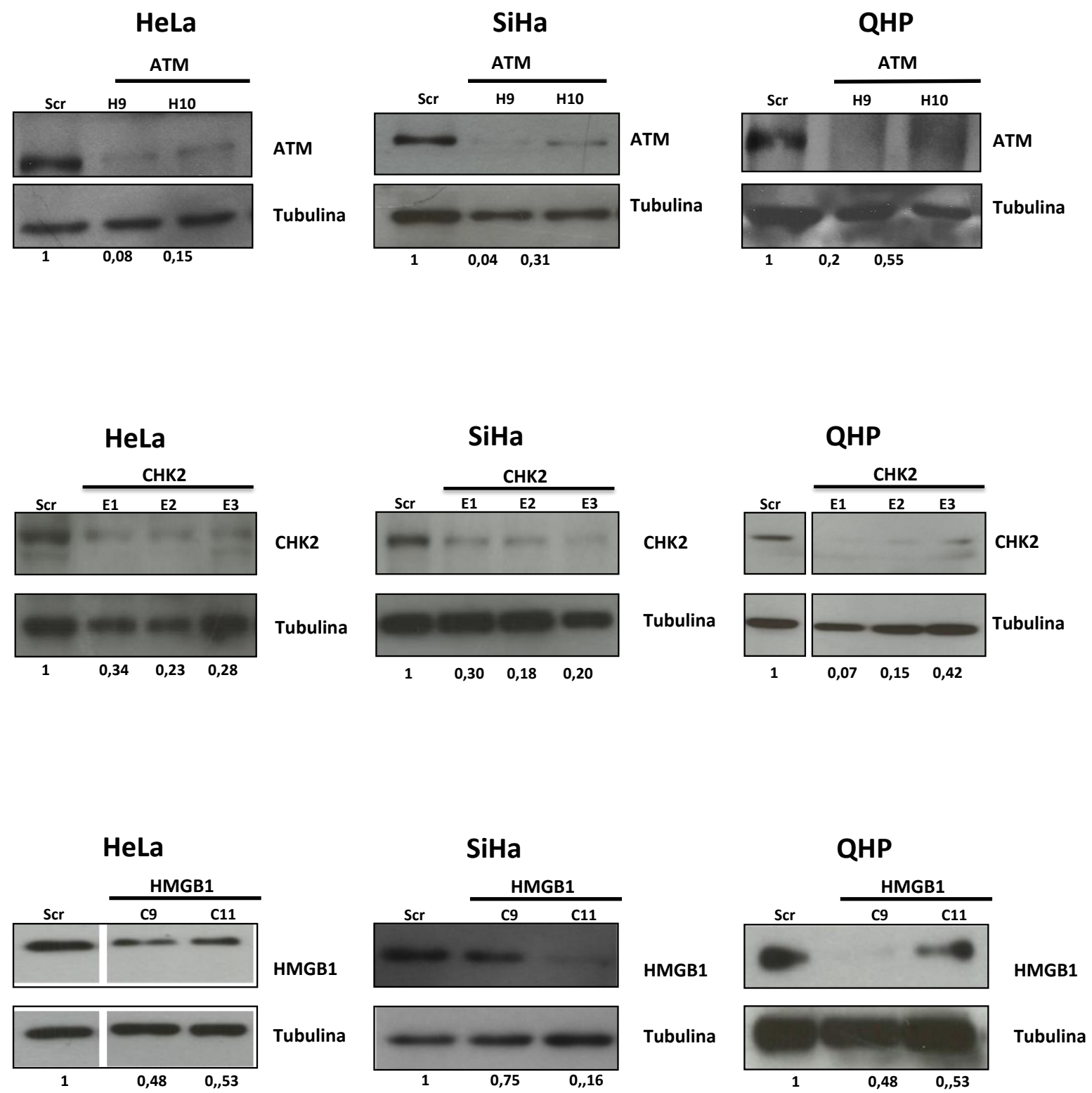

Figura 15 - Determinação dos níveis das proteínas ATM, CHEK2 e HMGB1 por western blot após o silenciamento gênico. As células foram semeadas em placas de $100 \mathrm{~mm}$ ( $1 \times 10^{6}$ células por placa) e após 24 horas foram transduzidas com os diferentes clones lentivirais. Após 48 horas estas células foram selecionadas com puromicina $(2,5 \mu \mathrm{g} / \mathrm{mL})$ e por fim tiveram suas proteínas extraídas. Foram utilizados $30 \mu \mathrm{g}$ de extratos proteicos totais obtidos a partir das amostras das culturas celulares das linhagens HeLa, SiHa e QHP transduzidas com os vetores lentivirais para o silenciamento de ATM (Clones H9 e H10) em gel de gradiente 4-12\%, CHEK2 (Clones E1, E2 e E3) em gel 10\% e HMGB1 (Clones C9 e C11) em gel $12 \%$ e os respectivos controle Scramble, o qual codifica uma sequência de nucleotídeos aleatória sem alvos celulares definidos. O controle de aplicação de quantidades equivalentes de proteínas foi realizado por detecção de tubulina e a quantificação foi realizada utilizando o software Image J. 


\subsection{Ensaio clonogênico e de soft ágar}

A capacidade de crescimento independentemente de contato célula a célula e de crescimento independente de substrato são características típicas de células transformadas. Para validar o potencial tumorigênico das células derivadas de câncer cervical HPV positivas sobre o efeito do silenciamento dos genes ATM, BRCA1, CHEK2 e HMGB1, silenciamos estes genes e avaliamos a capacidade de formação de colônias e de crescimento independente de ancoragem das diferentes linhagens celulares. A contagem das colônias foi realizada duas semanas após o plaqueamento. Assim, observamos uma redução da formação de colônias das células tumorais silenciadas para ATM, CHEK2, BRCA1 e HMGB1, quando comparadas ao controle (células transduzidas com lentivírus expressando um shRNA Scramble) (Figura 16). Para o ensaio clonogênico em soft ágar as colônias foram contadas 30 dias após o plaqueamento. Observamos por este método uma redução significava do crescimento independente do substrato das linhagens tumorais silenciadas com os clones de ATM, CHEK2, BRCA1 e HMGB1, quando comparadas com os controles Scramble (Figura 17).

\subsection{Ensaio de proliferação celular}

Para confirmação da redução da capacidade proliferativa, realizamos uma curva de proliferação celular, a qual foi obtida a partir da contagem de células, do primeiro ao oitavo dia, em câmara de Neubauer. A partir desta análise, observamos que a inibição dos genes ATM, CHEK2, BRCA1 e HMGB1 apresentaram um efeito antiproliferativo nas células tumorais, porém não alterou o perfil proliferativo dos QHP silenciados (Figura 18). Estes resultados sugerem que ATM, CHEK2, BRCA1 e HMGB1 são importantes genes na proliferação das células tumorais HPV positivas e que o silenciamento provoca um aumento do tempo de dobramento celular (doubling time). 
56
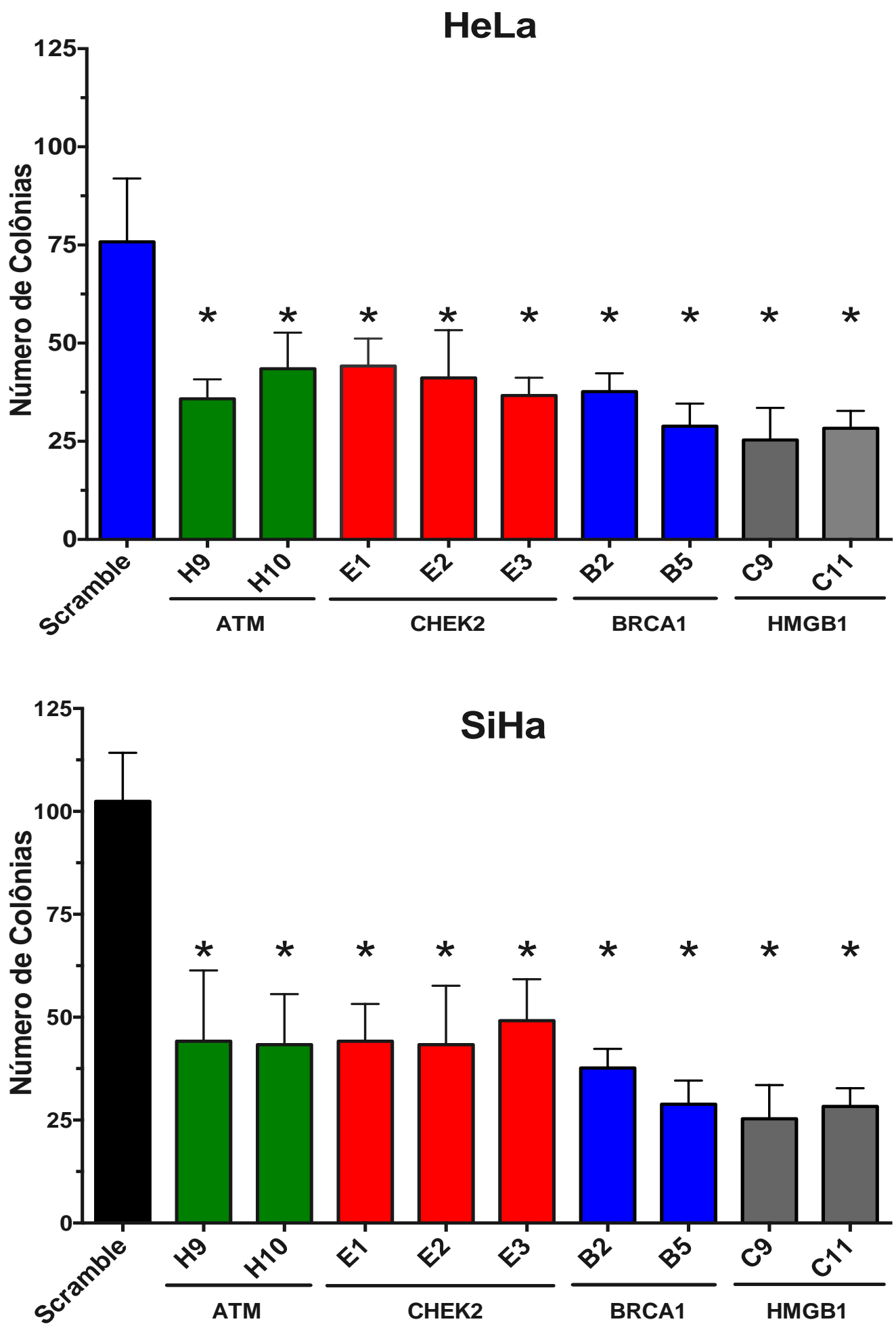

Figura 16 - Efeito do silenciamento dos genes ATM, CHEK2, BRCA1 e HMGB1 no potencial clonogênico de células HeLa e SiHa. As células silenciadas foram semeadas em placas de 6 poços (100 células por poço) e após 14 dias foram fixadas com solução de etanol e corados com cristal violeta. Estas linhagens silenciadas apresentaram menor capacidade de formação de colônias quando comparadas com as células controle (células transduzidas com o shRNA Scramble). Resultado confirmado por meio de 3 experimentos independentes. (Teste $t$ Student $p<0,005)$ 

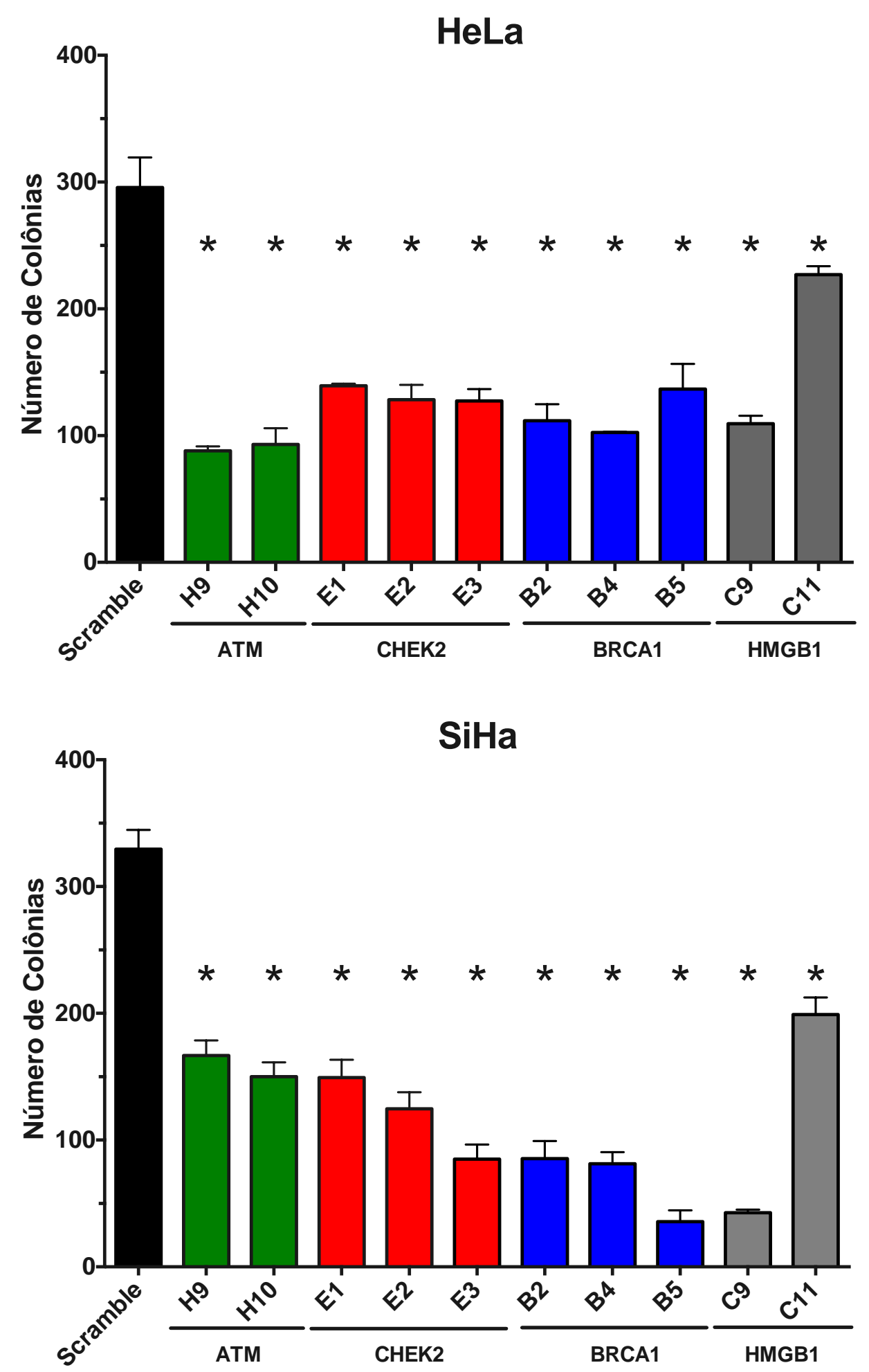

Figura 17 - Efeito do silenciamento dos genes ATM, CHEK2, BRCA1 e HMGB1 no potencial de crescimento independente de ancoragem de células HeLa e SiHa. As células silenciadas foram semeadas em placas de 24 poços (500 células por poço) e após 30 dias foram corados com MTT. Estas linhagens silenciadas apresentaram menor capacidade de crescimento independente do substrato quando comparadas com as células controle (células transduzidas com o shRNA Scramble). Resultado confirmado por meio de 3 experimentos independentes. (Teste t Student $p<0,005$ ) 

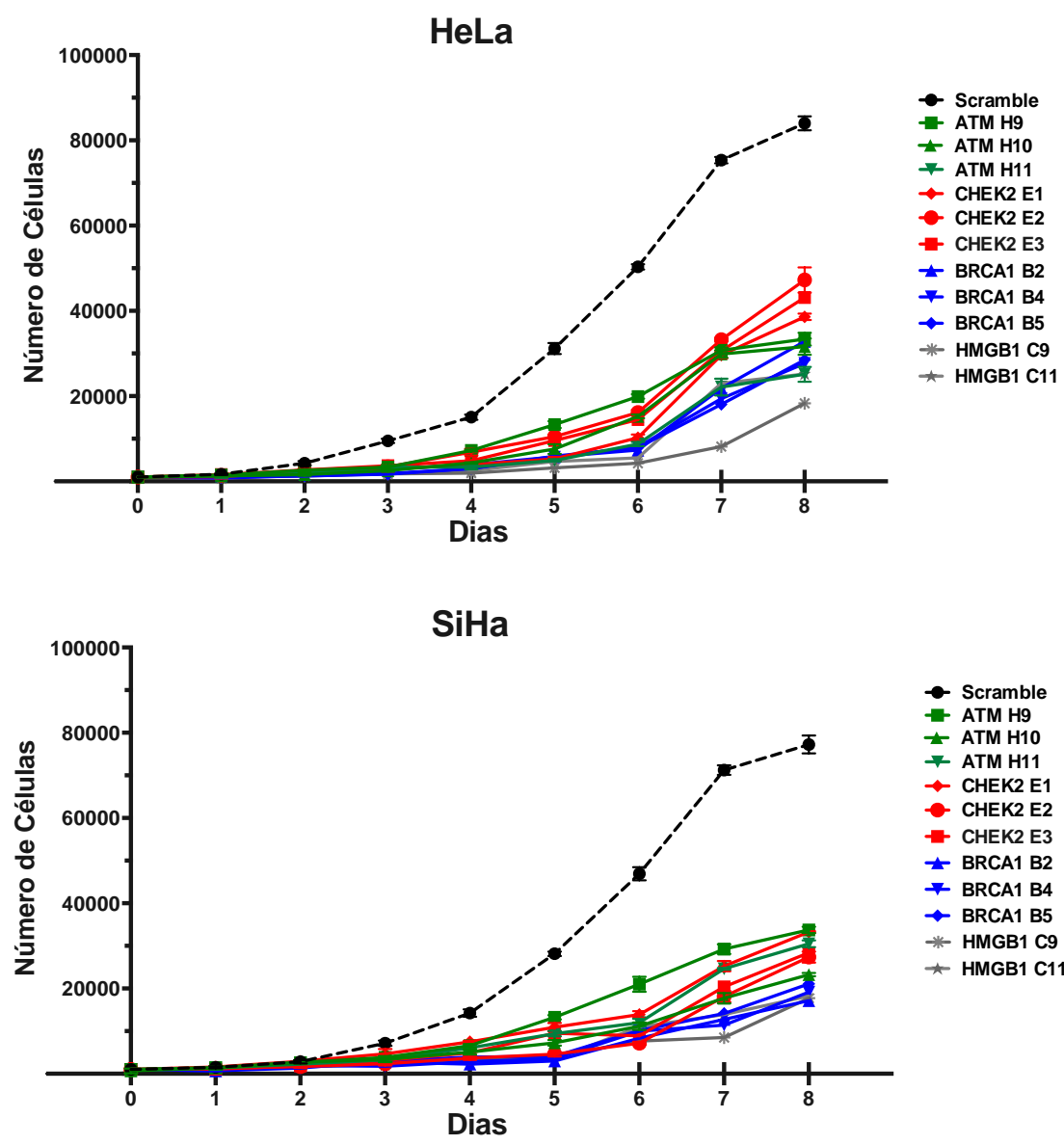

- Scramble - ATM H9 × ATM H10 - CHEK2 E1

- CHEK2 E2

- CHEK2 E3 + BRCA1 B2 - BRCA1 B4 - BRCA1 B5 * HMGB1 C9 * HMGB1 C11

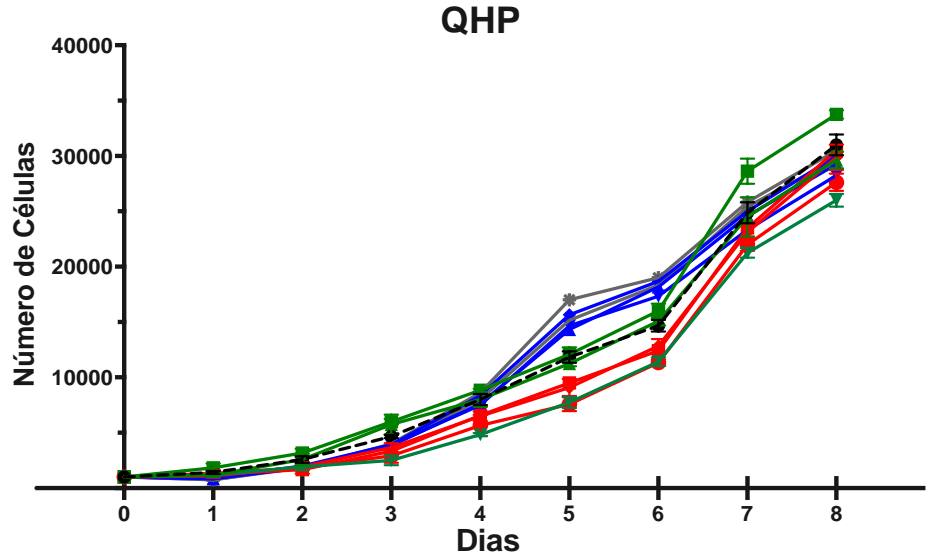

- Scramble - ATM H9 + ATM H10

+ ATM H11

CHEK2 1

- CHEK2

- CHEK2 E3

+ BRCA1 B2

- BRCA1 B4

$\checkmark$ BRCA1 B5

- HMGB1 C9

- HMGB1 C11

Figura 18 - Curva de Crescimento das células tumorais HeLa e SiHa e dos Queratinócitos Humanos Primários silenciadas para os genes ATM, CHEK2, BRCA1e HMGB1. As células foram semeadas em placas de 24 poços (1000 células por poço) e a proliferação celular foi avaliada do primeiro ao oitavo dia, pela contagem celular em triplicata. A proliferação celular das linhagens tumorais foi afetada pelo silenciamento dos genes ATM, CHEK2, BRCA1 e HMGB1 quando comparadas com o controle (células transduzidas com shRNA scramble). Todavia nenhum efeito foi observado no silenciamento de QHP silenciados para BRCA1 e HMGB1. O resultado foi confirmado por meio de três experimentos independentes. 


\subsection{Efeito do silenciamento gênico em queratinócitos expressando as oncoproteínas virais}

No processo de carcinogênese mediada por HPV, as oncoproteínas E6 e E7 são altamente expressas e causam inúmeras alterações celulares, as quais levam a instabilidade genômica. Com o intuito de relacionar o efeito observado na redução da viabilidade das células tumorais silenciadas para os genes ATM, CHEK2, BRCA1 e HMGB1 com as oncoproteínas virais, silenciamos estes mesmos genes em culturas de QHP transduzidos com os genes E6 e/ou E7 de HPV16. Por meio da análise de redução de Alamar Blue, observamos uma maior redução da viabilidade dos QHP que expressavam as oncoproteínas E6E7 quando silenciados para estes genes, enquanto o controle (QHP) manteve um mesmo perfil de viabilidade entre os silenciamentos (Figura 19). Quando silenciamos estes genes em QHP, os quais expressavam somente $\mathrm{E} 6$, identificamos uma redução da viabilidade celular apenas para os clones de ATM, CHEK2 e BRCA1. O silenciamento de HMGB1 não teve uma expressiva redução da viabilidade em QHP que expressavam a oncoproteína E6. Ao analisar o efeito de E7 na viabilidade de QHP silenciados para estes genes, observamos uma alteração do perfil identificado na expressão da oncoproteína E6. Os clones de HMGB1 tiveram uma expressiva redução da viabilidade na presença de E7, enquanto os clones de ATM, CHEK2 e BRCA1 apresentaram um perfil similar ao identificado no controle (Scramble). Estes dados sugerem que a redução da viabilidade celular mediada pelo silenciamento de ATM, CHEK2 e BRCA1 está relacionada a expressão e atividade da oncoproteína E6 de HPV16. Enquanto, a redução da viabilidade observada pelo silenciamento de HMGB1 está relacionada a expressão e atividade da oncoproteína E7 de HPV16. 


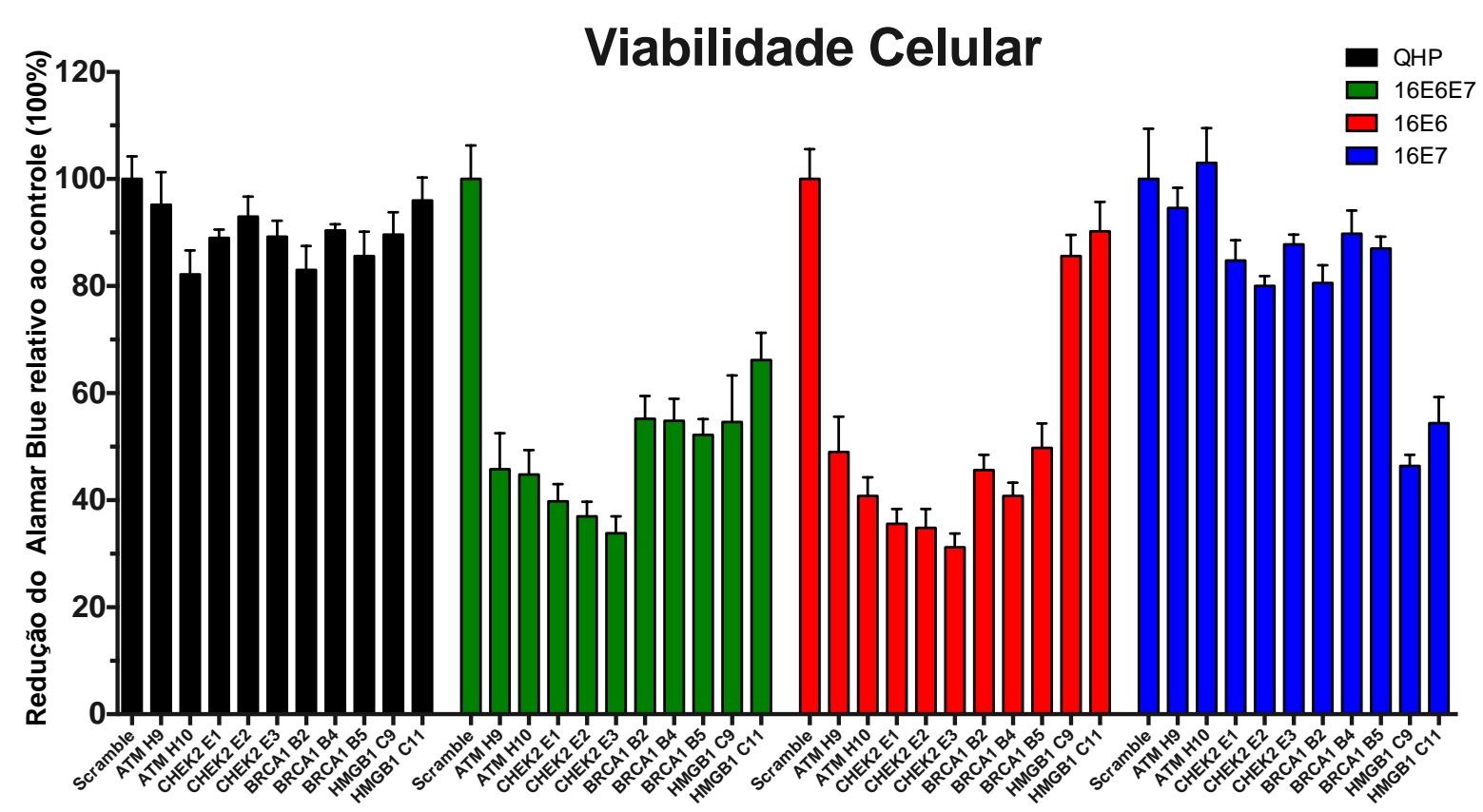

Figura 19 - Efeito do silenciamento dos genes ATM, CHEK2, BRCA1 e HMGB1 na viabilidade de QHP transduzidos com as oncoproteínas virais E6 e/ou E7 de HPV16. As células transduzidas e posteriormente silenciadas foram semeadas em placas de 96 poços (5000 células por poço) e após 120 horas tiveram sua viabilidade avaliada pela redução de Alamar Blue. $O$ silenciamento dos genes ATM, CHEK2 e BRCA1 provocou uma expressiva redução da viabilidade de QHP que expressavam E6E7 ou somente E6 de HPV16, quando comparados aos QHP normais ou que expressavam E7de HPV16. Enquanto o silenciamento de HMGB1 levou a uma redução da viabilidade de QHP que expressavam E6E7 ou somente E7 de HPV16, quando comparados aos QHP normais ou que expressavam somente E6 de HPV16. Os experimentos foram realizados três vezes em octuplicatas.

\subsection{Efeito do uso de fármacos para a inibição de ATM e CHEK2}

Para determinar a importância da via de ATM na viabilidade de linhagens celulares derivadas de tumores da cérvice uterina analisamos o efeito da inibição da proteína ATM. Esta proteína, a qual se encontra upstream na via de reparo, foi inibida com dois fármacos: cafeína e KU-55933. A cafeína é um inibidor de inespecífico de ATM capaz também de inibir ATR. Estas proteínas são chaves da regulação dos checkpoints G1-S e G2-M. Já a droga KU-55933 é um inibidor específico de ATM. A proteína CHK2, a qual está downstream a ATM, foi inibida com o fármaco Inibidor de CHK2 II hidratado, a qual inibe especificamente CHK2. A concentração dos fármacos inibidores de ATM e CHK2 foram determinadas pelo Índice de Citotóxidade $50 \%\left(\mathrm{IC}_{50}\right)$ a partir do gráfico de dose-resposta das células 
tumorais (Figura 20). Nossos resultados mostraram que a inibição de ATM ou de CHK2 resulta em uma marcada redução da proliferação e viabilidade das linhagens tumorais, quando comparadas a QHP (Figura 21). Visando confirmar a existência de uma relação entre a atividade de ATM ou de CHK2 e a presença das oncoproteínas virais, analisamos o efeito destes fármacos em QHP transduzidos com vetores retrovirais que expressam E6 e/ou E7 de HPV16. Foi observado que QHP quando expressam as proteínas E6 ou E6E7 de HPV 16 são mais sensíveis ao efeito inibitório de ATM ou de CHK2, quando comparados aos QHP. Todavia, a expressão da proteína E7 de HPV16 em QHP torna estas células mais resistentes à inibição de ATM, possivelmente pelo acúmulo de p53 em QHP que expressam somente E7 (Pei et al., 1998) (Figura 22). Esta resistência adquirida à inibição de ATM na presença de E7 não foi observada para o inibidor de CHK2, o que sugere que esta proteína downstream a via possa ser regulada por outros fatores. Para validar se o efeito da redução de viabilidade está relacionado a capacidade da oncoproteína E6 em degradar p53, inibimos ATM e CHK2 em QHP que expressavam o mutante amino terminal E6/8S9A10T, o qual é defectivo na degradação de p53, porém desempenha as demais funções relacionadas a E6. Os QHP que expressavam a proteína E6 mutante se mostraram menos sensíveis ao efeito inibitório de ATM, quando comparados aos QHP que expressavam as proteínas E6 selvagem ou E6E7 de HPV 16 (Figura 22). Para confirmar a dependência da degradação de p53 no efeito da redução da viabilidade, inibimos ATM e CHK2 em QHP que expressavam a oncoproteína E6 de HPV16, porém silenciados para proteína ubiquitina-ligase E6AP, a qual é fundamental no processo de degradação de p53 via proteassoma. O silenciamento de E6AP levou a uma maior resistência dos QHP expressando E6 de HPV16 aos inibidores de ATM ou de CHK2, quando comparados aos QHP que expressavam E6 de HPV16, mas com níveis normais de expressão de E6AP (Figura 22). Desta forma, estes resultados confirmam que a redução da viabilidade celular causada pela inibição de ATM e CHK2 é dependente da expressão de E6 e de sua capacidade de degradar p53. 

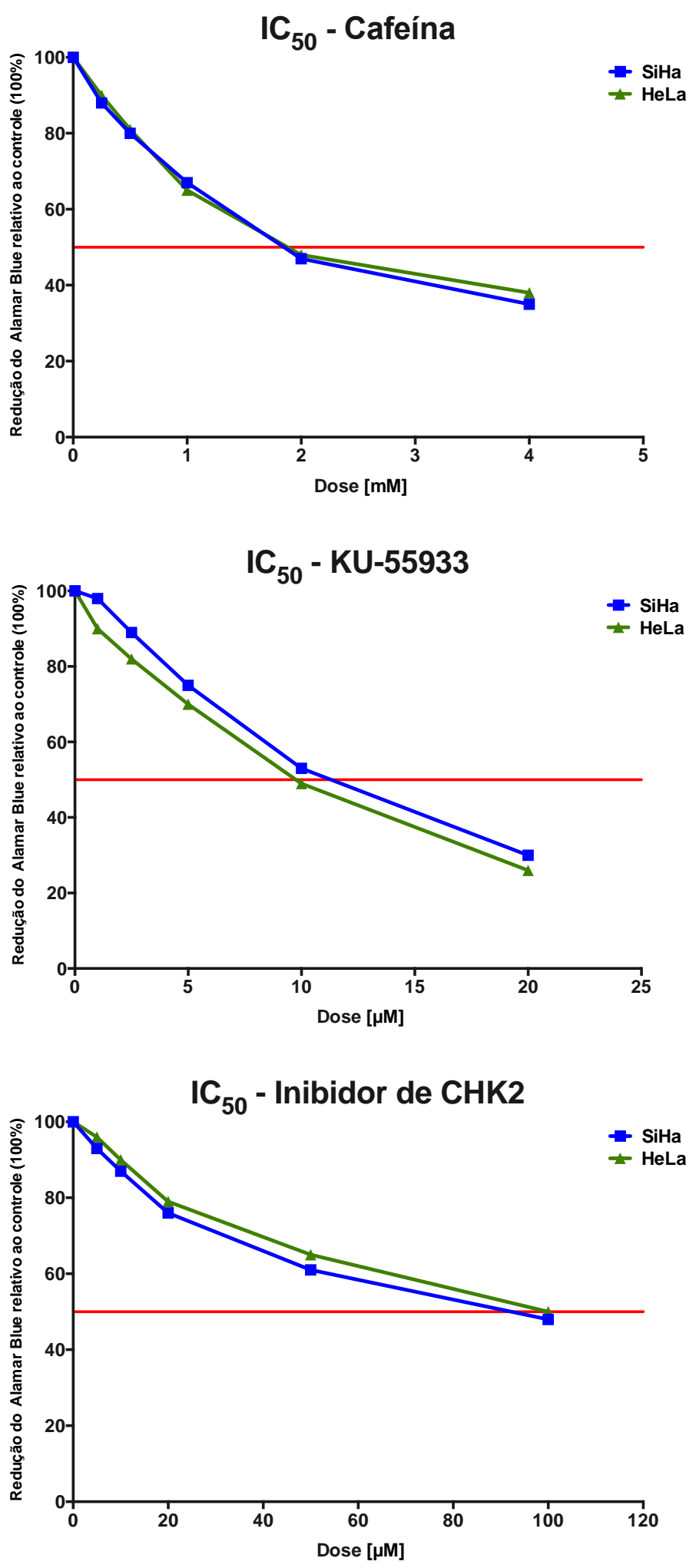

Figura 20 - Determinação da concentração inibitória 50\%. Culturas de células HeLa e SiHa foram semeadas em placas de 96 poços (5000 mil células por poço) e após 24h foram tratadas com concentrações crescentes de cafeína, KU-55933 ou inibidor de CHK2 II hidratado. Após 72 horas tiveram sua viabilidade avaliada pela redução do Alamar Blue. A concentração inibitória 50\% identificada foi de 2 mM para Cafeína, $10 \mu \mathrm{M}$ para KU-55933 e $100 \mu \mathrm{M}$ para inibidor de CHK2 II hidratado. 

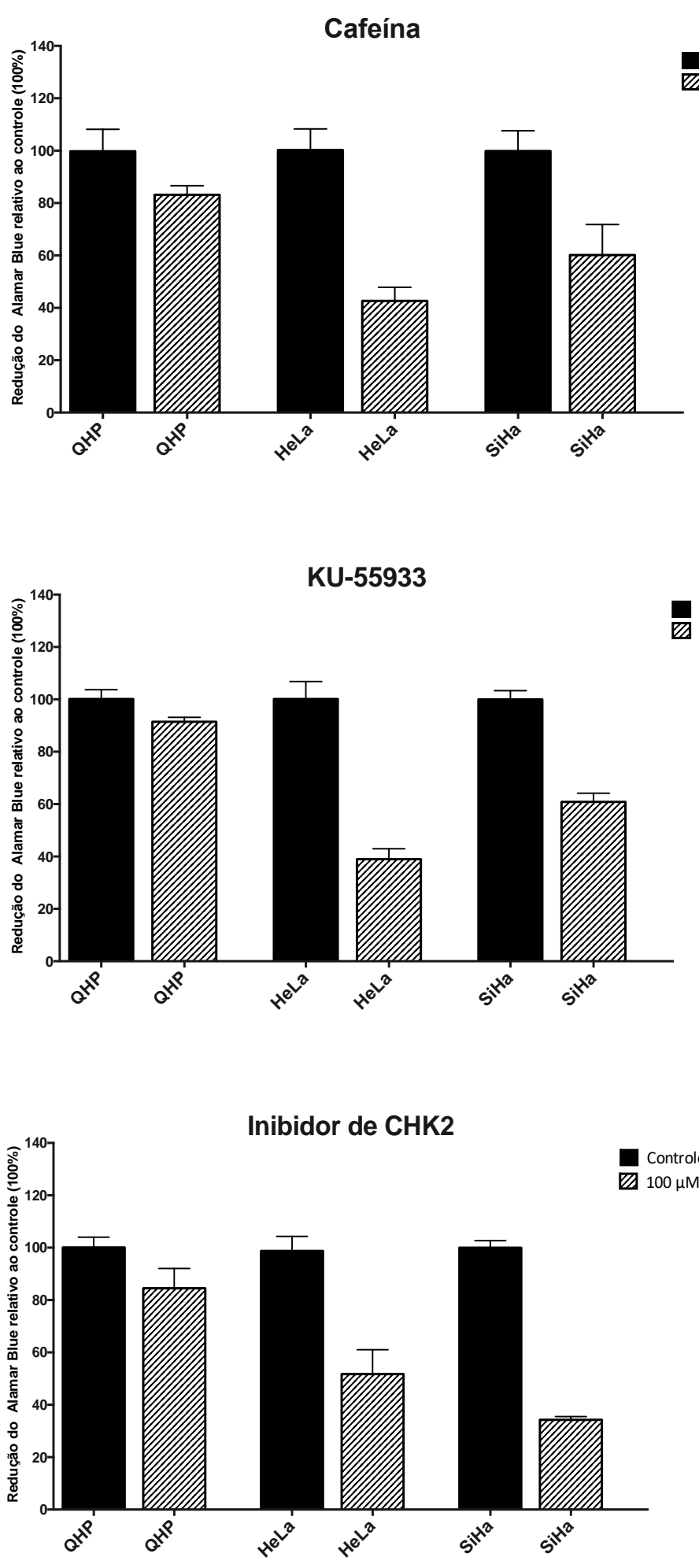

Figura 21 - Efeito da inibição de ATM e CHK2 por meio de fármacos nas linhagens celulares tumorais e em QHP normais. As células foram semeadas em placas de 96 poços (5000 células por poço) e após $24 \mathrm{~h}$ foram tratadas com cafeína ( $2 \mathrm{mM}), \mathrm{KU}$ $55933(10 \mu \mathrm{M})$ ou inibidor de CHK2 II hidratado $(100 \mu \mathrm{M})$. Após 72 horas tiveram sua viabilidade avaliada pela redução do Alamar Blue. A inibição de ATM resultou em maior redução da viabilidade e proliferação das células tumorais, quando comparadas aos seus respectivos controles e a QHP normais. 

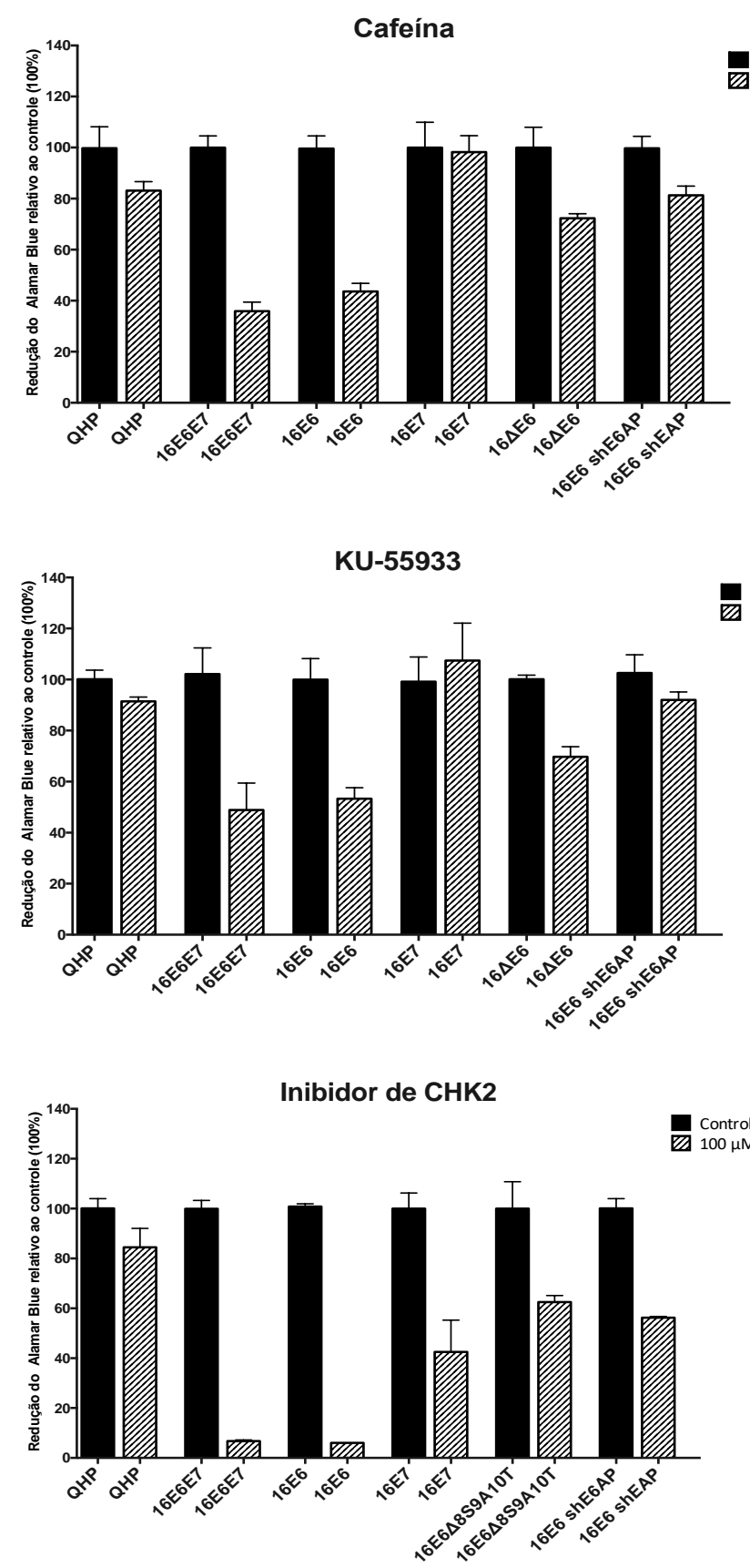

Figura 22 - Efeito da inibição de ATM e CHK2 por meio de fármacos nas linhagens de QHP normais e QHP expressando E6 e/ou E7 de HPV16, E6 mutante de HPV16 ou E6 de HPV16 silenciado para a ubiquitina-ligase E6AP. As células foram semeadas em placas de 96 poços (5000 células por poço) e após $24 \mathrm{~h}$ foram tratadas com cafeína (2 mM), KU-55933 (10 $\mu \mathrm{M})$ ou inibidor de CHK2 II hidratado $(100 \mu \mathrm{M})$. Após 72 horas tiveram sua viabilidade avaliada pela redução do Alamar Blue. A inibição de ATM ou de CHK2 resultou em maior redução da viabilidade e proliferação dos QHP expressando E6 ou E6E7, quando comparados aos QHP normais. A linhagem de QHP expressando E7 se mostrou mais resistente ao efeito das drogas inibidoras de ATM, quando comparado aos QHP normais, mas este mesmo efeito não foi observado para o inibidor de CHK2. A expressão de um gene mutante de E6 de HPV16, defectivo na degradação de p53, ou o silenciamento de E6AP levou a uma maior resistências destas células aos efeitos causados pela inibição de ATM ou CHK2, quando comparados aos QHP expressando E6 de HPV16. 


\subsection{Efeito da inibição de ATM e CHK2 combinado a indução de danos ao DNA}

No processo de carcinogênese, mediada ou não por HPV, as células tumorais acumulam inúmeras alterações celulares. Muitas destas alterações estão relacionadas a maquinaria de reparo de dano ao DNA, o que provavelmente deixa estas células cancerosas mais dependentes a um número reduzido de vias de reparo de DNA funcionais. A maquinaria de reparo de DNA é fundamental para a sobrevivência e a proliferação destas células, sobretudo quando estas são tratadas com quimioterápicos indutores de dano ao DNA. Desta forma, terapias que combinem indutores de dano ao DNA com inibidores expecíficos de proteínas chaves da maquinaria de reparo podem representar uma estratégia eficiente no tratamento de câncer. Esta abordagem no tratamento de câncer tem se demonstrado muito útil e com pequenos efeitos colaterais em células normais, as quais apresentam vias alternativas e não alteradas de reparo de dano ao DNA.

Para melhor compreender os mecanismos por trás dos efeitos observados na redução da viabilidade e proliferação celular das linhagens tumorais, combinamos o tratamento dos fármacos inibidores das proteínas da maquinaria de reparo (ATM e CHK2) com agentes causadores de dano ao DNA (doxorrubicina e cisplatina). A doxorrubicina é um fármaco amplamente utilizado no tratamento do câncer e tem capacidade de intercalar ao DNA e bloquear a atividade da topoisomerase II, resultando em quebras de fita dupla de DNA (Binaschi et al., 1997). Já a cisplatina, também utilizada no tratamento do câncer, interage com o DNA impedindo sua replicação e levando a quebras de fita simples e dupla de DNA (Sherman et al, 1985; Eastman, 1990). Os resultados observados revelaram que a indução de danos ao DNA provocada pelo tratamento com doxorrubicina ou cisplatina não levaram a uma significativa redução da viabilidade das linhagens tumorais HPV positivas (HeLa e SiHa), porém foi capaz de causar danos ao DNA, identificados pela detecção de $Y$ H2AX fosforilado (Figura 23A-B). Quando combinamos 0 tratamento de doxorrubicina com os fármacos inibidores de ATM ou CHEK2, observamos um efeito maior na redução da viabilidade celular de HeLa e $\mathrm{SiHa}$, quando comparados com as células tratadas apenas com os inibidores de ATM ou de CHK2 (Figura 23A). Todavia, este efeito aditivo não foi observado entre as combinações dos inibidores de ATM ou de CHK2 com cisplatina. Curiosamente, a combinação com cisplatina 
deixou as células resistentes à inibição de ATM ou de CHK2, quando comparadas com as células tratadas apenas com os inibidores. Para avaliar se esta resistência foi adquirida pela ativação da via de ATR, a qual responde preferencialmente aos danos de quebras de fita simples gerados também por cisplatina, resolvemos inibir simultaneamente ATM e ATR com o uso de cafeína. O tratamento com cafeína combinado com cisplatina levou a uma redução da viabilidade das linhagens tumorais. Sugerindo que a resistência mediada por cisplatina à inibição de ATM ou de CHK2 se dá pela ativação da via de ATR. Por sua vez o tratamento com doxorrubicina e cisplatina não alterou a viabilidade das células tumorais HPV positivas, mas quando combinados com os inibidores de ATM ou CHK2, a redução da viabilidade foi a mais evidente em relação aos demais tratamentos.

Uma vez demonstrado aqui, que o efeito de redução da viabilidade celular é dependente da degradação de p53 (Figura 22). Resolvemos avaliar o efeito destes fármacos inibidores de ATM ou CHK2 e dos agentes indutores de danos ao DNA, na viabilidade da linhagem tumoral HPV negativa (C33A), a qual apresenta mutação no gene de p53. A linhagem C33A se demonstrou mais sensível ao tratamento com doxorrubicina em relação as linhagens tumorais HPV positivas. Além disso, a linhagem C33A também apresentou redução da viabilidade quando tratada com os inibidores de ATM ou de CHK2, mas não sofreu um efeito aditivo com a combinação dos agentes causadores de dano ao DNA. Nesta linhagem não observamos o efeito de resistência mediado por cisplatina diante a inibição de ATM ou de CHK2. Sugerindo que a presença de p53 mutado em C33A possa interferir no processo de ativação da via de ATR. $O$ tratamento simultâneo com doxorrubicina e cisplatina, diferentemente de HeLa e SiHa, reduziu a viabilidade de C33A e quando combinados com os inibidores de ATM ou CHK2, teve um efeito ainda mais expressivo na redução da viabilidade celular. Desta forma, estes resultados observados em C33A confirmam a relação existente entre a inibição de ATM ou de CHK2 com a inativação de p53 na redução da viabilidade celular. E que esta redução tem um efeito aditivo quando também tratadas com indutores de dano ao DNA. 
A)
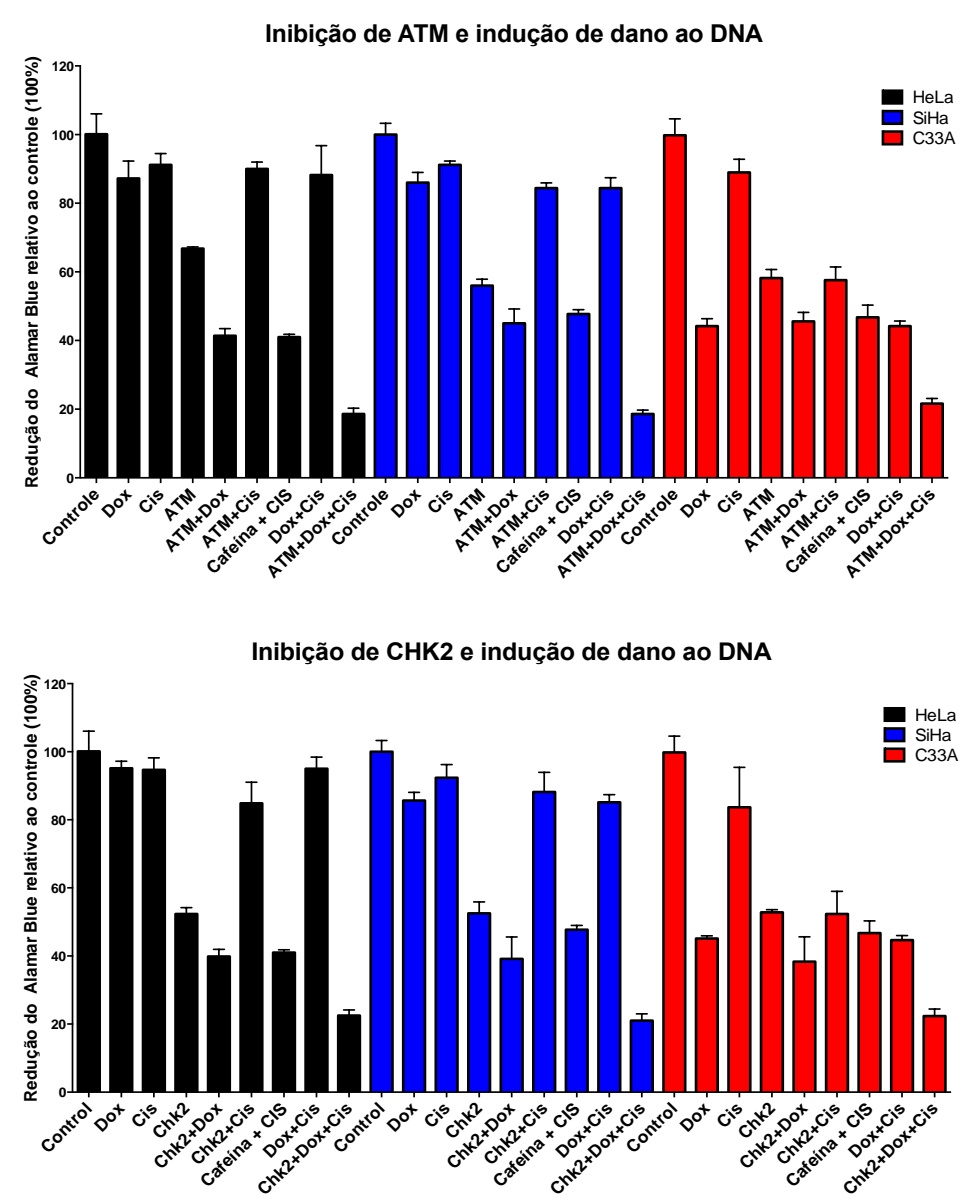

B)
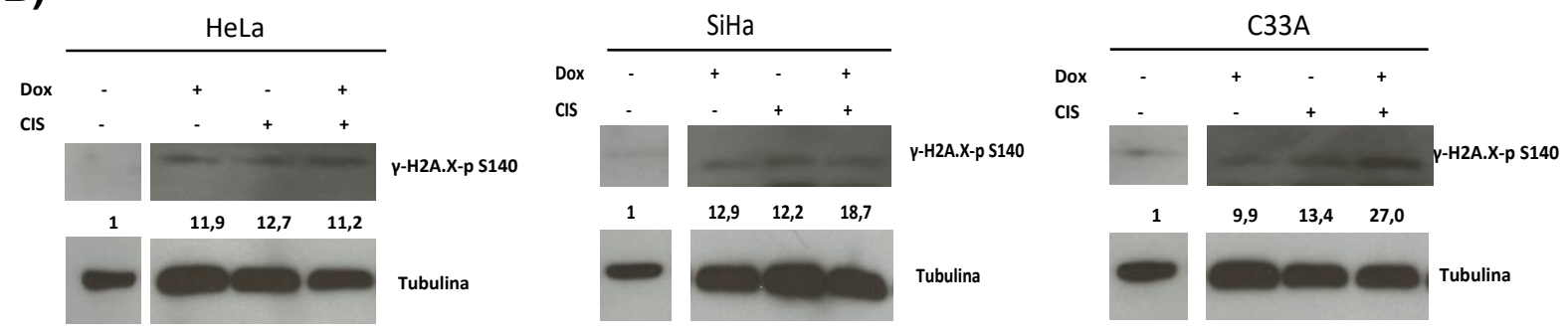

Figura 23 - Efeito da inibição de ATM e de CHK2 nas linhagens tumorais quando induzidas ao dano ao DNA por doxorrubicina e cisplatina. A) As células foram semeadas em placas de 96 poços (5000 células por poço) e após $24 \mathrm{~h}$ foram tratadas com o inibidor de ATM (KU-55933) $(10 \mu \mathrm{M})$, cafeína $(2 \mathrm{mM})$, inibidor de CHK2 II hidratado $(100 \mu \mathrm{M})$, doxorrubicina $(1 \mu \mathrm{M})$ e/ou cisplatina $(1 \mu \mathrm{M})$. Após 72 horas tiveram sua viabilidade avaliada pela redução do Alamar Blue. A inibição de ATM ou de CHK2 resultou na redução da viabilidade e proliferação, a qual foi acentuada quando combinada com os tratamentos de doxorrubicina e/ou cisplatina. B) A confirmação do dano causado ao DNA pela ação de doxorrubicina e/ou cisplatina foi confirmada por meio de Western blot. Foram utilizados $30 \mu \mathrm{g}$ de extratos proteicos totais obtidos a partir das amostras das culturas de HeLa, SiHa e C33A tratadas com doxorrubicina (1 $\mu \mathrm{M})$ e/ou cisplatina $(1 \mu \mathrm{M})$. O controle de aplicação de quantidades equivalentes de proteínas foi realizado por detecção de tubulina e a quantificação foi realizada utilizando o software Image $\mathrm{J}$. 


\subsubsection{Avaliação das linhagens de QHP transduzidas}

A redução da viabilidade celular observada nas linhagens tumorais é dependente de E6 e de sua capacidade de degradar p53. E o uso de agentes indutores de dano ao DNA leva a um efeito aditivo na redução da viabilidade celular das linhagens tumorais HPV positivas (HeLa e SiHa), mas não da linhagem HPV negativa (C33A). Desta forma, para confirmar se este efeito aditivo observado com os indutores de dano ao DNA está relacionado a expressão das oncoproteínas virais, estabelecemos culturas de QHP transduzidos com E6 e/ou E7 de HPV16, além de E6 mutante ou E6 de HPV16, porém com E6AP silenciada. Os resultados mostraram que QHP que expressavam E6E7 ou somente E6 de HPV16 foram mais sensíveis ao tratamento com doxorrubicina e/ou cisplatina combinados ou não com os inibidores de ATM ou de CHK2, quando comparados aos QHP normais ou que expressavam somente a oncoproteína E7 de HPV16 (Figura 24). O efeito aditivo causado pela combinação entre doxorrubicina ou cisplatina com os inibidores da via de reparo foi evidente em QHP transduzidos com E6E7 ou somente E6, quando tratados com o inibidor de ATM, mas não com o inibidor de CHK2. A inibição de CHK2, independente de induzir danos ao DNA, reduziu acentuadamente a viabilidade de QHP transduzidos com E6E7 ou apenas E6 de HPV16. Além disso, neste ensaio não foi observado resistência aos inibidores de ATM ou de CHK2 quando tratados com cisplatina. Sugerindo que as células tumorais apresentam outras alterações, além da presença das oncoproteínas, as quais podem alterar o perfil de sensibilidade ou resistência aos tratamentos. Por fim, as linhagens de QHP transduzidas com E6 mutante ou com E6 de HPV16 silenciada para E6AP apresentaram maior resistência aos tratamentos de doxorrubicina e/ou cisplatina combinadas aos inibidores de ATM ou de CHK2, quando comparados aos QHP que expressavam E6 de HPV16 (Figura 25). Estes dados confirmam que a redução da viabilidade é dependente da expressão de E6 e da sua capacidade de degradar p53. E que a indução de danos ao DNA leva a uma efeito aditivo na redução da viabilidade na presença de E6, quando ATM é inibido, mas não CHK2. 
Inibição de ATM/ATR e indução de danos ao DNA

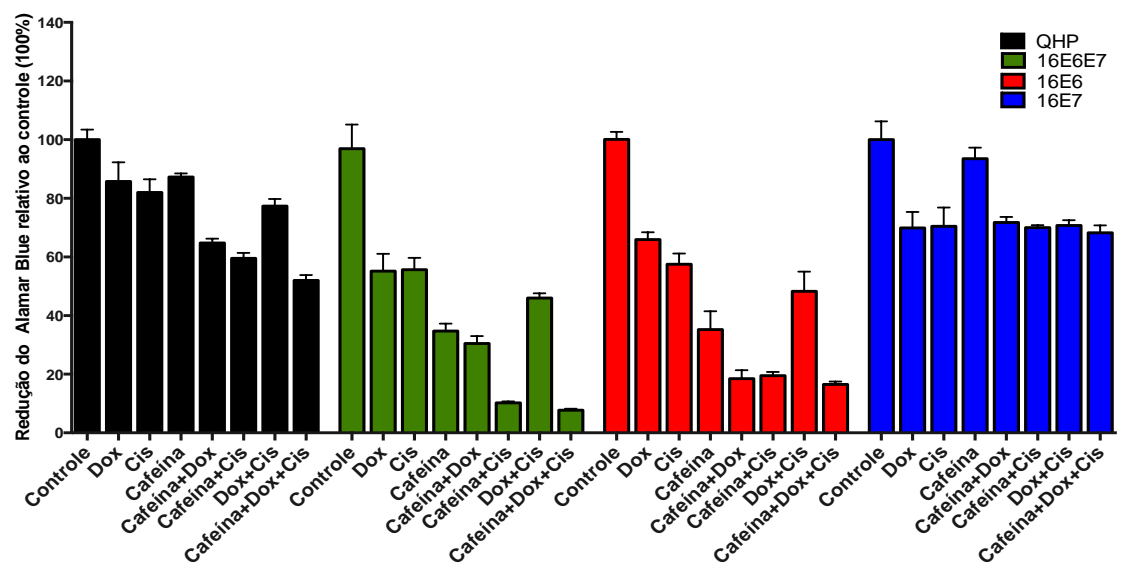

Inibição de ATM e indução de danos ao DNA

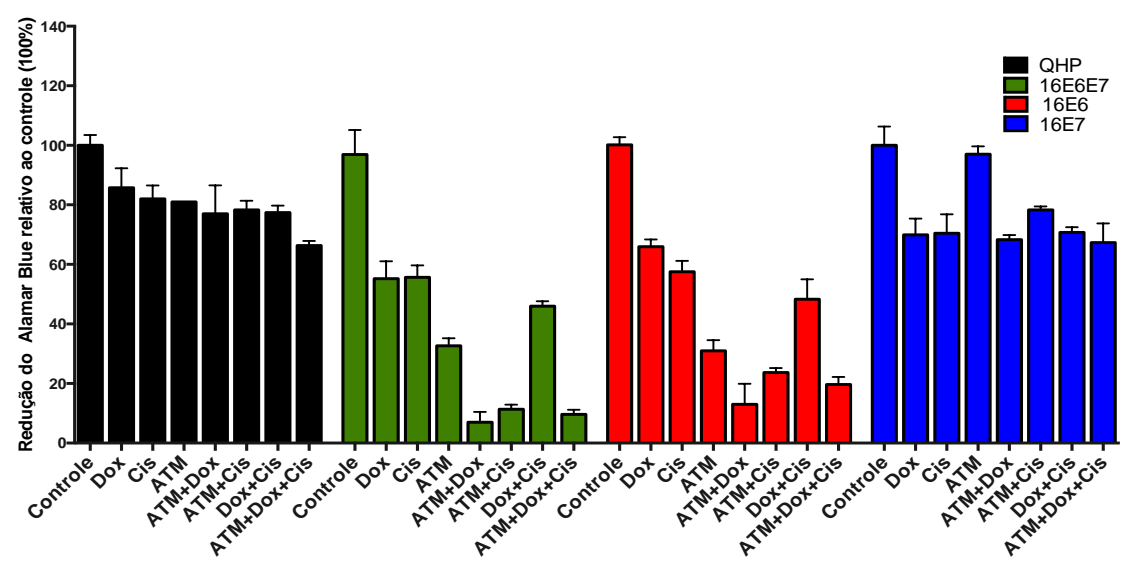

Inibição de CHK2 e indução de dano ao DNA

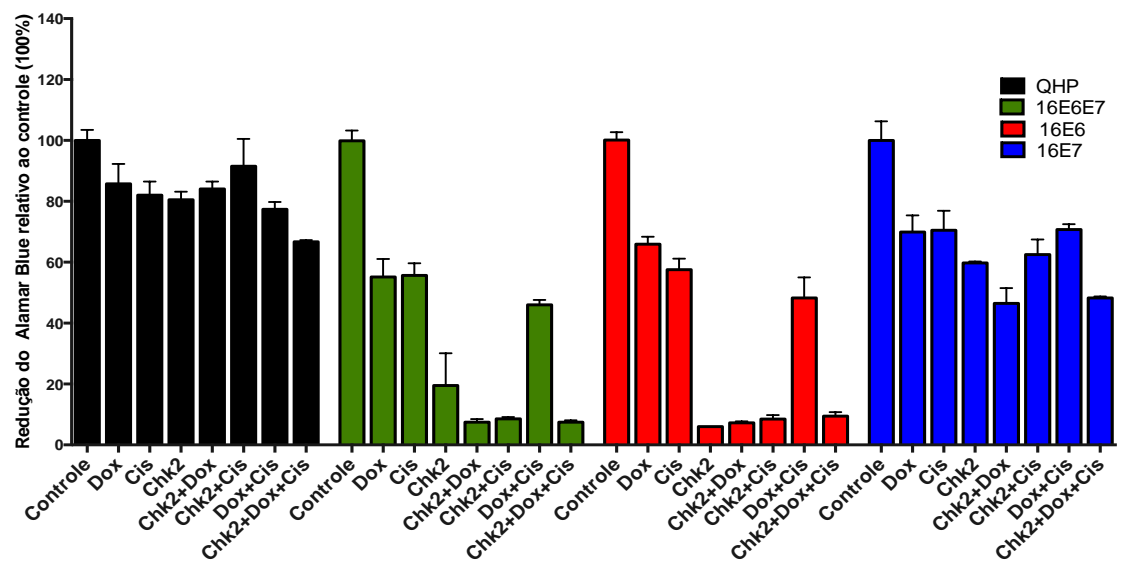

Figura 24 - Efeito da inibição de ATM e de CHK2 nas linhagens de QHP transduzidas com os vetores de E6 e/ou E7 de HPV16, quando induzidas ao dano ao DNA por doxorrubicina e/ou cisplatina. As células transduzidas foram semeadas em placas de 96 poços (5000 células por poço) e após $24 \mathrm{~h}$ foram tratadas com 0 inibidor de ATM (KU-55933) $(10 \mu \mathrm{M})$, cafeína $(2 \mathrm{mM})$, inibidor de CHK2 II hidratado $(100 \mu \mathrm{M})$, doxorrubicina $(1 \mu \mathrm{M})$ e/ou cisplatina $(1 \mu \mathrm{M})$. Após 72 horas tiveram sua viabilidade avaliada pela redução do Alamar Blue. A inibição de ATM ou de CHK2 resultou na redução da viabilidade e proliferação das células que expressavam E6. A inibição de ATM, mas não de a de CHK2, combinada com os tratamentos de doxorrubicina e/ou cisplatina reduziu a viabilidade celular. 
Inibição de ATM/ATR e indução de danos ao DNA

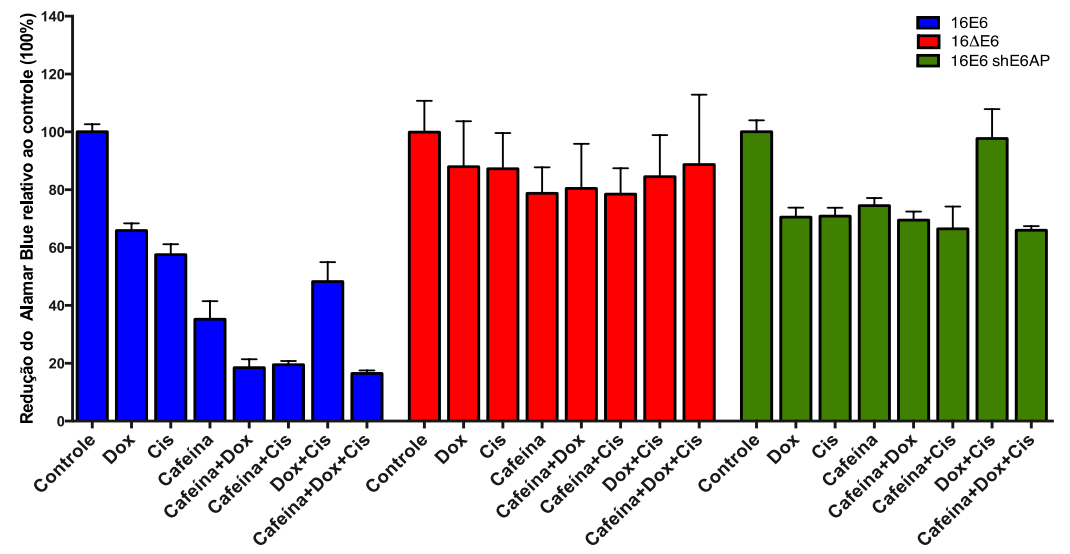

Inibição de ATM e indução de danos ao DNA

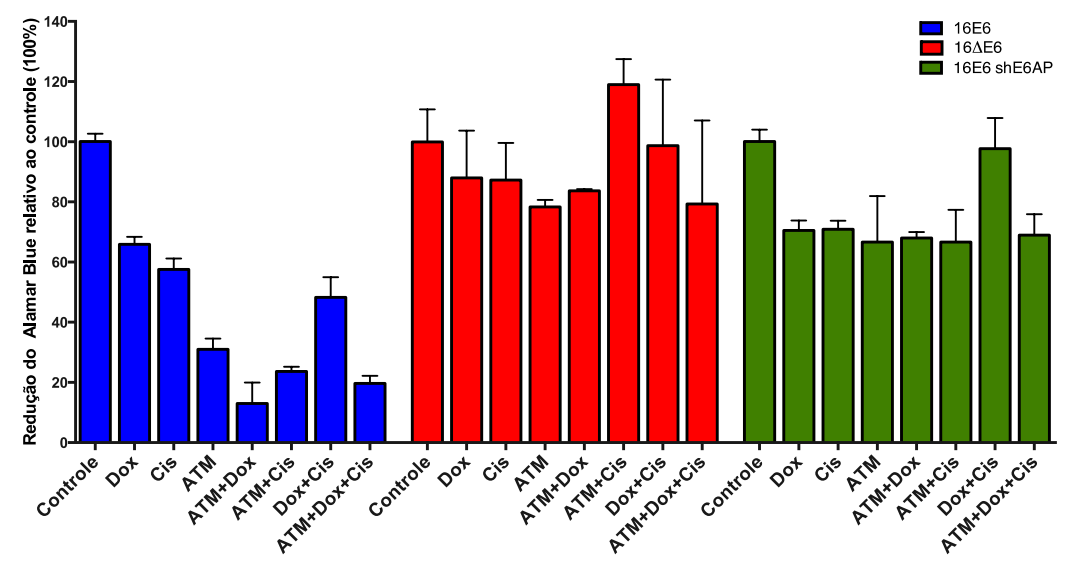

Inibição de CHK2 e indução de dano ao DNA

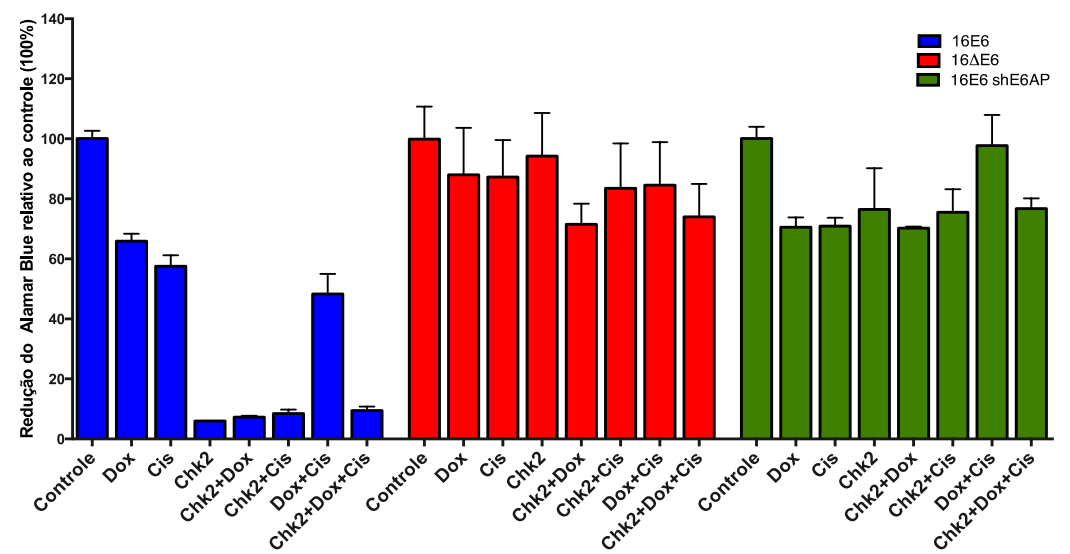

Figura 25 - Efeito da inibição de ATM e de CHK2 nas linhagens de QHP transduzidas com os vetores de E6 de HPV16, E6 mutante de HPV16 e E6 de HPV16 silenciada para E6AP, quando induzidas ao dano ao DNA por doxorrubicina e/ou cisplatina. As células transduzidas foram semeadas em placas de 96 poços (5000 células por poço) e após $24 \mathrm{~h}$ foram tratadas com o inibidor de ATM (KU-55933) (10 $\mu \mathrm{M})$, cafeína $(2 \mathrm{mM})$, inibidor de CHK2 II hidratado $(100 \mu \mathrm{M})$, doxorrubicina $(1 \mu \mathrm{M})$ e/ou cisplatina $(1 \mu \mathrm{M})$. Após 72 horas tiveram sua viabilidade avaliada pela redução do Alamar Blue. A inibição de ATM ou de CHK2 resultou na redução da viabilidade e proliferação das células que expressavam E6. Todavia a expressão de E6 mutante ou o silenciamento de E6AP reverteu o fenótipo observado e levou a uma maior resistência aos tratamentos. 


\subsection{Níveis de ativação da via de ATM em células HeLa tratadas com inibidor de ATM e doxorrubicina}

O tratamento com inibidores das proteínas da maquinaria de reparo, assim como o tratamento com os agentes causadores de dano ao DNA levam a alterações celulares, as quais ativam processo de sinalização. Com o intuito de melhor compreender os mecanismos envolvidos nos efeitos observados, diante os tratamentos com fármacos inibidores da maquinaria de reparo e/ou agentes indutores de dano ao DNA, avaliamos a cinética de ativação, a partir da fosforilação do resíduo de serina 1981, da proteína ATM ao longo do tempo. Células HeLa foram tratadas com o inibidor de ATM (KU-55933) e/ou com o agente indutor de dano ao DNA (doxorrubicina) e tiveram a cinética de fosforilação de ATM avaliada por 72 horas por meio de western blot. O tratamento com doxorrubicina levou a detecção de ATM fosforilado logo nas primeiras 2 horas de exposição, a qual se acentuou ao longo do tempo e se sustentou durante as 72 horas de avaliação (Figura 26A). Não foi detectado níveis basais de fosforilação no resíduo de serina 1981 de ATM em células HeLa, logo o tratamento com KU-55933 não levou em alterações no perfil de detecção de ATM fosforilado ao longo do tempo (Figura 26B). O tratamento combinado entre o inibidor de ATM e doxorrubicina levou a detecção de ATM fosforilado apenas 4 horas após o tratamento, o qual foi sustentado ao longo das 72 horas de tratamento. Todavia, os níveis de ATM fosforilado detectados no tempo de 72 horas na presença do inibidor foi menor do que os níveis de ATM, quando tratados somente com doxorrubicina (Figura 26C). Logo, o inibidor de ATM é capaz de retardar a resposta da via de ATM, assim como reduzir os níveis de fosforilação na presença de danos ao DNA. Para uma melhor conclusão acerca da cinética de ativação de ATM, outros resíduos de fosforilação devem ser avaliados, assim como a ativação de proteínas downstream a ATM. 
A)

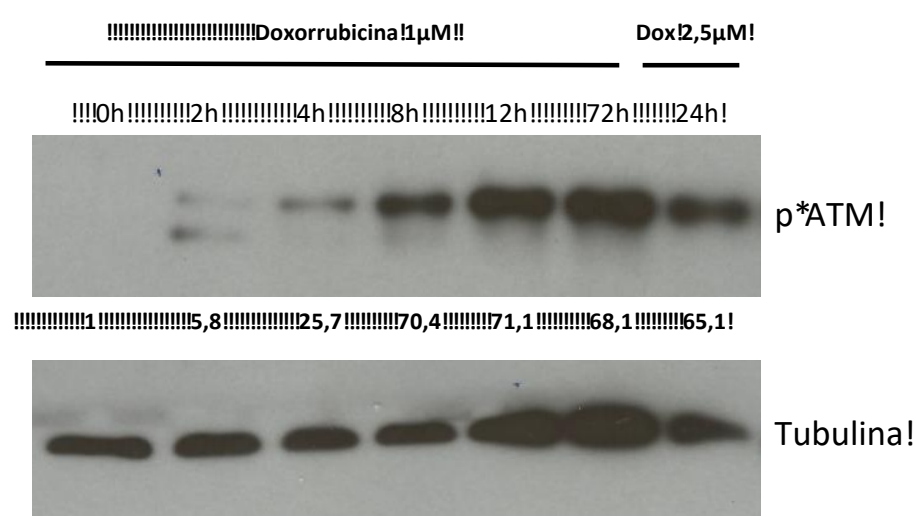

B)

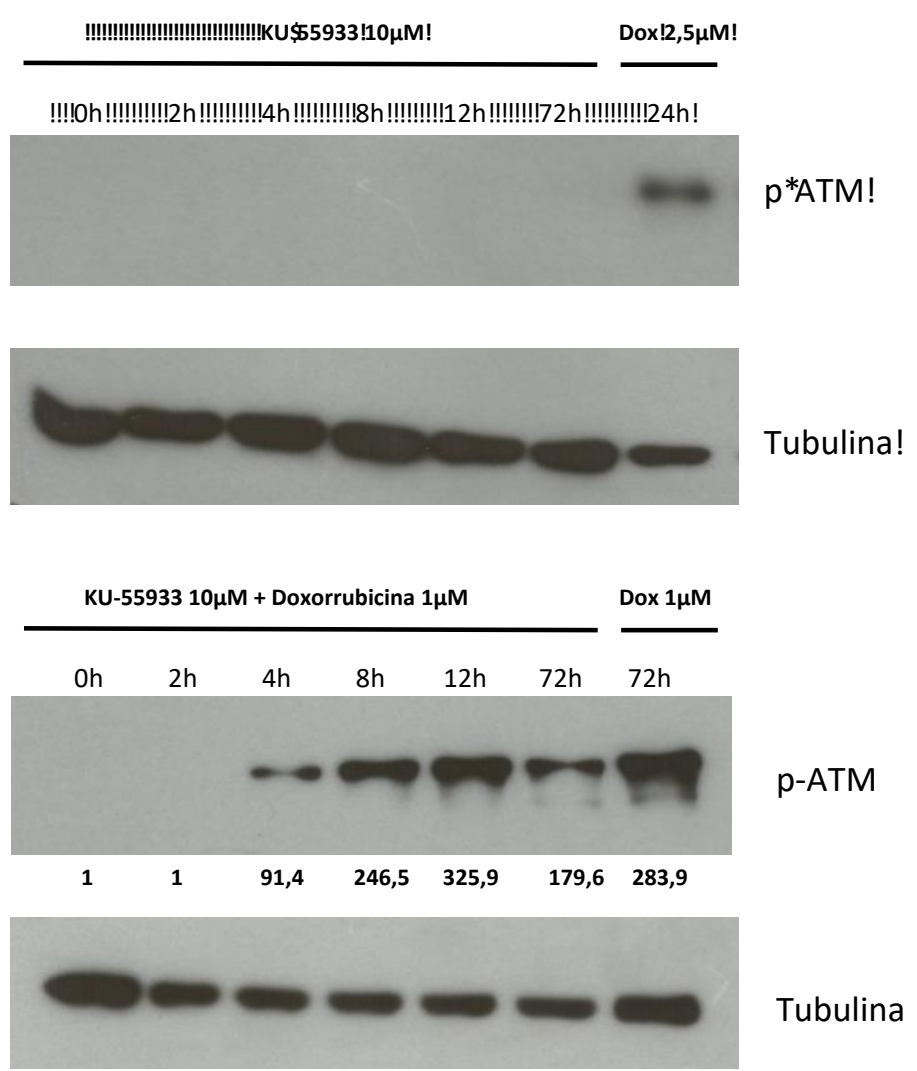

Figura 26 - Determinação dos níveis de fosforilação do resíduo de serina 1981 da proteína ATM mediante o tratamento com inibidor de ATM ou doxorrubicina. Células HeLa foram semeadas em placas de 6 poços $\left(3 \times 10^{5}\right.$ células por poço $)$ e após 24 horas foram tratadas com o inibidor de ATM (KU-55933) e/ou doxorrubicina por 72 horas. Os extratos proteicos foram obtidos nos seguintes tempos: 0 h, $2 \mathrm{~h}, 4 \mathrm{~h}, 8 \mathrm{~h}, 12 \mathrm{~h}$ e $72 \mathrm{~h}$ após os tratamentos. Foram utilizados $30 \mu \mathrm{g}$ de extratos proteicos totais em gel de gradiente $4-12 \%$ para detecção de ATM fosforilado. A) Tratamento com $1 \mu \mathrm{M}$ de doxorrubicina; B) Tratamento com $10 \mu \mathrm{M}$ de inibidor de ATM (KU-55933); C) Tratamento com $10 \mu \mathrm{M}$ de inibidor de ATM (KU-55933) e $1 \mu \mathrm{M}$ de doxorrubicina. O controle de aplicação de quantidades equivalentes de proteínas foi realizado por detecção de tubulina e a quantificação foi realizada utilizando o software Image J. 


\section{DISCUSSÃO}

Os mecanismos de reparo de dano ao DNA tem o papel de manter à integridade do genoma celular por meio de elaboradas vias de sinalização, as quais detectam os danos ao DNA e recrutam proteínas efetoras para que as lesões sejam reparadas. Acredita-se que mais de 20 mil lesões sejam induzidas de forma endógena por dia ao DNA, as quais podem levar a morte celular ou a mutações (Friedberg, 2006). Além disso, diferentes agentes exógenos podem lesionar a molécula de DNA, tais como: luz UV, radiação ionizante, poluição atmosférica, cigarro, quimioterápicos e até mesmo infecções virais. Desta forma, mecanismos eficientes de reparo de DNA são fundamentais para a correção de danos ou ativação de mecanismo de morte celular programada para eliminação de células com mutações potencialmente tumorais (Sacar et al., 2004).

A maquinaria de reparo de dano ao DNA também responde a presença viral, a partir de mecanismos antivirais de eliminação de DNA ou RNA exógenos (Revisado por Micha, 2014). Todavia, muitos vírus, inclusive o HPV, apresentam mecanismos que modulam a resposta de dano ao DNA, favorecendo a entrada da fase $S$, para que ocorra a replicação viral. A expressão das oncoproteínas virais E6 e E7 de HPV são capazes de ativar a maquinaria de reparo de DNA, mas por outro lado impedem que fatores downstream a via, tais como p53, levem a parada do ciclo celular ou a eliminação viral. Diferentes estudos mostraram que as proteínas da maquinaria de reparo de dano ao DNA são essenciais para a amplificação e manutenção do genoma viral de HPV (Gillespie et al., 2012; Moody e Laimins, 2009). Estas observações sugerem que a maquinaria de reparo de DNA é fundamental para a manutenção da estabilidade do genoma celular e também tem um papel crucial no processo de manutenção e amplificação do genoma viral.

A manutenção estável do genoma do HPV nas camadas basais do epitélio é fundamental para a persistência viral e consequentemente um risco para o desenvolvimento tumoral (Bordel e Laimins, 2011; Chen et al., 2011; Goodman et al., 2007). Quando não eliminados, o genoma viral pode se integrar ao genoma da célula hospedeira e oferecer vantagens proliferativas, as quais levam a instabilidade genômica, acúmulo de danos ao DNA e até mesmo o câncer (Goodman et al., 2007). Durante o desenvolvimento tumoral muitos genes das vias de reparo se encontram alterados, sobretudo os regulados pelas vias de p53 e pRb, o que 
favorece o acúmulo de mutações gênicas por ineficiência dos mecanismos de reparo de dano ao DNA. Ativação de proto-oncogenes e inativação de genes supressores de tumor favorecem a transformação celular, permitindo a proliferação e progressão tumoral. Todavia, as vias de reparo de dano ao DNA, mesmo que alteradas e com mecanismos reduzidos de ação, atuam de forma a manter o mínimo de integridade necessária para garantir a sobrevivência e proliferação das células tumorais. Este fato, torna a célula tumoral altamente dependente de determinadas vias de reparo de DNA, as quais podem ser exploradas como alvos terapêuticos para o tratamento de câncer.

O desenvolvimento de terapias específicas, as quais são capazes de combater as células tumorais a partir de suas vulnerabilidades, tem sido amplamente exploradas pelo princípio da letalidade sintética. A letalidade sintética descreve uma condição celular na que duas (ou mais) mutações não alélicas e não essências, que não são letais individualmente, tornam-se mortais quando presentes na mesma célula. Em outras palavras, uma célula pode sobreviver quando uma das vias é alterada. Por outro lado, a perda simultânea de duas ou mais vias redundantes, que inativa uma função essencial da célula, leva a sua morte. A letalidade sintética também pode ocorrer quando um gene é inativado por mutação e outro gene é inativado através de inibidores específicos ou pela expressão de proteínas virais. Por exemplo, foi demonstrada a existência de letalidade sintética entre a ausência do supressor de tumor PTEN (phosphatase and tensin homologue on chromosome 10) e a inibição de mTOR (mammalian target of rapamycin) por um análogo da rapamicina (Neshat et al, 2001; Podsypanina et al, 2001). Além disso, este princípio foi utilizado para estabelecer a existência de letalidade sintética entre p53 e as quinases PAK3 e SGK2 em células transformadas por HPV (Balwin et al., 2010). Nestas células, as quinases PAK3 e SGK2 foram inativadas por lentivírus que carregavam shRNA específicos. A inativação de p53 foi atingida pela expressão da oncoproteína E6 de HPV16.

Desta forma, no presente estudo, silenciamos de maneira sistemática 116 genes envolvidos nas diferentes vias de reparo de dano ao DNA e 73 genes supressores de tumor em linhagens derivadas de carcinomas de colo uterino (HeLa e $\mathrm{SiHa}$ ) visando determinar a existência de letalidade sintética entre os genes silenciados e àqueles cuja atividade é alterada pela presença do HPV. Este estudo possibilita desenvolver novas estratégias para o tratamento de lesões associadas a 
este vírus e que possivelmente poderão ser aplicadas ao estudo de outros tumores de origem viral ou não.

Nossos resultados mostraram que no final do nosso screening um grupo de 39 shRNAs, correspondentes a 22 genes, foram capazes de reduzir a viabilidade e proliferação das linhagens tumorais HeLa e SiHa em pelo menos $30 \%$, quando comparado ao controle. Porém, o grande desafio deste trabalho é como reduzir a viabilidade das linhagens tumorais, sem alterar a viabilidade das células normais. Desta forma, validamos estes 39 clones de shRNA, capazes de reduzir a viabilidade das linhagens tumorais, em culturas de queratinócitos humanos primários. Foram identificados 2 clones para HMGB1, 2 clones para ATM, 3 clones para CHEK2 e 3 clones para BRCA1, os quais foram capazes de reduzir a viabilidade e proliferação das linhagens tumorais, sem afetar as células normais. Interessantemente os genes ATM, CHEK2 e BRCA1 são genes de uma mesma via de reparo de DNA, o que contribui para um estudo mais detalhado da importância desta via para a viabilidade e proliferação destas células.

O gene HMGB1, por sua vez, codifica para proteínas do grupo de alta mobilidade box 1 , as quais são proteínas não-histonas presentes em altas concentrações no núcleo celular na forma hipoacetilada. A proteína HMGB1 foi inicialmente identificada como uma proteína de ligação ao DNA nuclear, tendo um papel na transcrição de vários genes, dos quais incluem genes relacionados ao desenvolvimento tumoral, tais como: E-selectina, TNFa, receptor de insulina e BRCA (Baldassarre et al., 2003; Brunetti et al., 2001; Fashena et al., 1992; Thanos e Maniatis, 1992). Estas proteínas interagem com as histonas no nucleossomo e com fatores de transcrição, modulam a transcrição gênica com grande importância para a transativação do gene de p53 (Banerjee e Kundu, 2003; Jayaraman et al., 1998). Quando hiperacetilado nos resíduos de lisina a proteína HMGB1 é translocada para o citosol e secretada pela atividade de p53, agindo como uma citocina e sinalizando para processos inflamatórios em casos de danos celulares (Bianchi, 2007; 2008; Davalos et al., 2013; Klune et al.,). As funções de HMGB1 podem ser resumidas conforme a Tabela 5.

Estudos recentes realizados em camundongos deficientes para HMGB1 mostraram o acúmulo de mutações no DNA pela perda da capacidade de reparo quando induzidos com agentes mutagênicos (Sabine et al, 2008). Vários trabalhos realizados in vivo tem demonstrado a importância de HMGB1 no sistema de reparo, 
sendo o preferencial ligante ao dano de DNA (Lanuszewska e Widlak, 2000; Ohndorf et al., 1999; Pasheva et al., 1998;). Estudos conduzidos com amostras de câncer cervical evidenciaram altos níveis de expressão de HMGB1, quando comparado à tecidos normais de colo uterino, e identificaram uma forte correlação entre os níveis de expressão de HMGB1 e o desenvolvimento tumoral (Hao et al., 2008).

Em nosso trabalho mostramos que o silenciamento de HMGB1 nas linhagens tumorais foi capaz de reduzir o potencial clonogênico e de crescimento independente de ancoragem destas células. Além disso, o silenciamento de HMGB1 levou a uma redução da proliferação celular, com um consequente aumento do tempo de dobramento das células transformadas. Indicando que HMGB1 desempenha um importante papel na manutenção, proliferação e sobrevivência das células tumorais. Uma análise mais detalhada, com o objetivo de estabelecer uma relação entre os efeitos observados e a atividade das oncoproteínas virais, mostrou que QHP transduzidos com E6E7 ou somente E7 de HPV16 tiveram sua viabilidade reduzida mediante o silenciamento de HMGB1. Estes dados mostram que a redução da viabilidade causada pelo silenciamento de HMGB1 é dependente da expressão e atividade da oncoproteína E7, sendo um possível caso de letalidade sintética. Em outros trabalhos realizados pelo nosso grupo observamos uma maior expressão da proteína HMGB1 em células tumorais HPV positivas e em QHP transformados com as oncoproteínas E6E7 ou somente E7 de HPV16. Além disso, foi demonstrado que QHP transduzidos com mutantes de E7 incapazes de degradar a proteína do retinoblastoma $(p R b)$, não foram capazes de induzir aumento de expressão de HMGB1 (Morale, 2016). Sugerindo desta forma, que a super expressão de HMGB1 possa estar diretamente associada a inativação de pRb e a liberação de fatores de transcrição associados a expressão de HMGB1.

Estudos realizados com amostras de câncer cervical e neoplasia intraepitelial cervical (NIC) mostraram que a expressão de HMGB1 tende a aumentar com a progressão do câncer cervical, sendo desta forma um possível indicador do prognóstico tumoral (Pang et al., 2014). Interessantemente, diferentes estudos sugerem que HMGB1 desempenha um papel no desenvolvimento de metástases e o relacionam com o pobre prognóstico em uma variedade de tumores, incluindo cancêr de próstata, mama, pâncreas e cólon (Bussemakers et al., 2015; Dolde et al., 2002; Fedele et al., 1996; Kuniyasu et al., 2003; Leman et al., 2003; Nestl et al., 2001; Ram et al., 1993; Takaha, 2002; Tarbe et al., 2001). Estas observações 
fortalecem ainda mais a importância do entendimento da importância de HMGB1 para a sobrevivência e proliferação das células tumorais HPV positivas.

Tabela 5 - Funções de HMGB1 e sua localização celular. Modificado de KANG et al., 2014.

\begin{tabular}{|c|c|}
\hline \multicolumn{2}{|c|}{ Localização } \\
\hline Intracelular & Extracelular \\
\hline \multicolumn{2}{|c|}{ Funções } \\
\hline $\begin{array}{c}\text { Ligação ao DNA } \\
\text { Chaperona de DNA } \\
\text { Remodelamento de DNA }\end{array}$ & $\begin{array}{l}\text { Citocina } \\
\text { Quimiocina } \\
\text { DAMP }\end{array}$ \\
\hline \multicolumn{2}{|c|}{ Processos Celulares } \\
\hline $\begin{array}{c}\text { Remodelamento e estabilidade } \\
\text { de Nucleossomo } \\
\text { Recombinação de DNA } \\
\text { Replicação } \\
\text { Reparo } \\
\text { Transcrição } \\
\text { Transferência Gênica } \\
\text { Telomerase } \\
\text { Entrega Gênica }\end{array}$ & $\begin{array}{c}\text { Diferenciação Celular } \\
\text { Inflamação e resposta imune } \\
\text { Migração Celular e Mestástase } \\
\text { Regeneração Tecidual } \\
\text { Morte de Bactérias } \\
\text { Proliferação e Morte Celular } \\
\text { Senescência } \\
\text { Biogênese de microRNA } \\
\text { Neurotransmissão }\end{array}$ \\
\hline
\end{tabular}


O genes ATM, CHEK2 e BRCA1, também identificados no nosso screening, fazem parte de uma mesma via de sinalização e reparo de DNA. O gene ATM (Ataxia Telangiectasia Mutated) codifica para a proteína ATM, a qual tem função de quinase e é recrutada e ativada na presença de quebras de fita dupla de DNA. Em resposta ao dano ao DNA, ATM é autofosforilada na serina 1981 e promove a fosforilação direta das proteínas CHK2 e BRCA1, as quais estão envolvidas na regulação dos pontos de controle ( $\mathrm{G} 1 / \mathrm{S}$ e $\mathrm{G} 2 / \mathrm{M})$ ), levando a parada do ciclo celular, o reparo de DNA ou indução de apoptose (Chen, 2000; Gatei et al., 2000; Gatei et al., 2001; Lee e Paull, 2007; Lee et al., 2000;). A proteína CHK2, quando ativada por ATM, também pode fosforilar e ativar a proteína BRCA1 (Gatei et al., 2001; Melcheionna et al., 2000). BRCA1 desempenha importantes funções celulares, tais como de ubiquitina-ligase E3, regulação do ciclo celular, transcrição gênica, transmissão de sinal de dano ao DNA e direcionamento das proteínas da maquinaria de reparo para os seus respectivos complexos (Mohammad e Yaffe, 2011; Narod e Foulkes, 2004; Wu, 2000).

Estudos recentes mostram que proteínas como ATM, BRCA1, RAD51 e CHK2, da maquinaria de reparo de DNA, relacionadas à via de reparo de quebras de fita dupla, são fundamentais para a amplificação do genoma de HPV (Hong e Laimins, 2013) e que a inibição desta via por meio de fármacos leva a um bloqueio da amplificação viral (Moody e Laimins, 2009). O vírus HPV é capaz de induzir a fosforilação de ATM, assim como seus substratos CHK2 e BRCA1 em células não diferenciadas ou em processo de diferenciação (Moody e Laimins, 2009). Esta ativação da via de ATM parece induzir uma fase $S$ ou G2/M, criando um ambiente propício para a replicação do genoma viral. A replicação de HPV ocorre de forma bidirecional, como em procariotos por replicação teta, mas pode alternar seu mecanismo de replicação para círculo rolante durante a fase de amplificação (Flores e Lambert, 1997). Esta alternância entre os mecanismos de replicação viral requer a ativação da via ATM em células em diferenciação para que ocorra a circularização do genoma viral após a clivagem dos concatemeros (Kadaja et al., 2009). Estes dados mostram que a via de ATM é fundamental para o processo de manutenção e amplificação viral. Todavia, poucos são os estudos que relacionam ATM ao desenvolvimento tumoral mediado por HPV.

Nossos dados, por sua vez, revelaram a importância da via de ATM para a viabilidade e sobrevivência de células derivadas de câncer cervical. Quando 
silenciados os gene ATM, CHEK2 ou BRCA1, houve uma marcada diminuição do potencial clonogênico das linhagens tumorais HPV positivas e também uma redução da capacidade de crescimento independente de ancoragem. Além disso, o silenciamento destes genes levou a uma significativa diminuição da proliferação das linhagens tumorais, sem alterar o perfil prolifetativo dos QHP. Sugerindo que esta via seja essencial na manutenção destas células transformadas por HPV.

Quando analisado o efeito da expressão das oncoproteínas virais de HPV na viabilidade de QHP silenciados para os genes ATM, CHEK2 e BRCA1, observamos uma maior redução da viabilidade e proliferação das linhagens de QHP que expressavam E6E7 ou somente E6. Este efeito observado no silenciamento das linhagens tumorais e nas linhagens QHP transduzidos com as oncoproteínas virais foi confirmado com a utilização de fármacos inibidores de ATM ou de CHK2. O tratamento com estes fármacos levou a uma redução da viabilidade das linhagens tumorais ou de QHP que expressavam E6E7 ou somente E6.

Poucos são os estudos que relacionam BRCA1 a tumores cervicais, porém estudos em câncer de mama e ovário correlacionam BRCA1 e PARP como sendo pares de letalidade sintética (Eskander e Tewari, 2014; Rosen e Pishvaian, 2014; Synowiec et al., 2014). A proteína poly(ADP-ribose) polymerase (PARP) tem papel relevante no reparo de quebra de fita simples de DNA e é incapaz de realizar o reparo quando a maquinaria de reparo de quebra de fita dupla (Recombinação Homóloga), a qual evolve BRCA1, está inativa (Nicola e Csaba, 2013). Zhang Y e colaboradores mostraram que BRCA1 é capaz de inibir a atividade da telomerase pela repressão de seu promotor e que as oncoproteínas E6 e E7 de HPV são capazes de alterar a atividade de BRCA1 no câncer cervical, liberando o promotor da telomerase (Zhang et al., 2005). 


\section{CONCLUSÕES}

Nossos dados mostram que os genes HMGB1, ATM, BRCA1 e CHEK2 desempenham um importante papel no câncer cervical. O silenciamento destes genes levou a redução do perfil proliferativo, diminuição do potencial clonogênico e de crescimento independente de ancoragem das células transformadas por HPV.

O silenciamento de HMGB1 levou a uma redução da viabilidade de QHP tranduzidos com vetores que expressavam E6E7 ou somente E7 de HPV16. Já a redução da viabilidade pelo silenciamento de ATM, CHEK2 e BRCA1 foi evidenciada em QHP que expressavam E6E7 ou somente E6 de HPV16.

O tratamento com fármacos inibidores de ATM ou CHK2 provocaram uma redução da viabilidade das linhagens tumorais e de QHP transduzidos com E6E7 ou apenas E6 de HPV16.

Linhagens de QHP que expressavam E6 de HPV16, deficiente na degradação de p53, não apresentaram alterações na viabilidade quando tratadas com os inibidores de ATM ou CHK2. Logo, a redução da viabilidade ocasionada pela inibição de ATM ou CHK2 depende da presença da oncoproteína E6 e de sua capacidade de degradar p53.

Observamos um efeito aditivo na redução da viabilidade das linhagens tumorais e em QHP transduzidos com E6E7 ou apenas E6 de HPV16, quando combinamos o tratamento com os inibidores de ATM ou de CHK2 com agentes indutores de dano ao DNA, doxorrubicina e/ou cisplatina. 


\section{REFERÊNCIAS*}

Alazawi W, Pett M, Strauss S, Moseley R, Gray J, Stanley M, Coleman N. Genomic imbalances in 70 snap-frozen cervical squamous intraepithelial lesions: associations with lesion grade, state of the HPV16 E2 gene and clinical outcome. Br J Cancer. 2004;91:2063-70.

Anacker DC, Gautam D, Gillespie KA, Chappell WH, Moody CA. Productive replication of human papillomavirus 31 requires DNA repair factor Nbs1. J. Virol. 2014;88:8528-44.

Ashrafi GH, Tsirimonaki E, Marchetti B, O'Brien PM, Sibbet GJ, Andrew L, Campos M. Down-regulation of MHC class I by bovine papillomavirus E5 oncoproteins. Oncogene. 2002;21:248-59.

Aza Blanc P, Cooper CL, Wagner K, Batalov S, Deveraux QL, Cooke MP. Identification of modulators of TRAIL-induced apoptosis via RNAi-based phenotypic screening. Mol. Cell. 2003;12;627-37.

Baldassarre G, Battista S, Belletti B, Thakur S, Pentimalli F, Trapasso F, Fedele M, Pierantoni G, Croce CM, Fusco A. Negative regulation of BRCA1 gene expression by HMGA1 proteins accounts for the reduced BRCA1 protein levels in sporadic breast carcinoma. Mol Cell Biol. 2003;23:2225-38.

Baldwin A, Grueneberg DA, Hellner K, Sawyer J, Grace M, Li W, Harlow E, Munger $\mathrm{K}$. Kinase requirements in human cells: $\mathrm{V}$. Synthetic lethal interactions between p53 and the protein kinases SGK2 and PAK3. Proc Natl Acad Sci USA. 2010;107(28):12463-68.

Banerjee S, Kundu TK. The acidic C-terminal domain and A-box of HMGB-1 regulates p53-mediated transcription. Nucleic Acids Res. 2003;31:3236-47.

Bernstein E, Caudy AA, Hammond SM, Hannon GJ. Role for a bidentate ribonuclease in the initiation step of RNA interference. Nature. 2001;409;363-6.

Bettencourt Dias M, Giet R, Sinka R, Mazumdar A, Lock WG, Balloux F et al.. Genome-wide survey of protein kinases required for cell cycle progression. Nature. 2004;432;980-7.

Bianchi ME. DAMPs, PAMPs and alarmins: all we need to know about danger. J Leukoc. Biol. 2007;81;1-5.

Binaschi M, Capranico G, Dal Bo L and Zunino F: Relationship between lethal effects and topoisomerase II-mediated double-stranded DNA breaks produced by anthracyclines with different sequence specificity. Mol Pharmacol. 1997;51;1053-59.

*De acordo com:

International Committee of Medical Journal Editors. [Internet]. Uniform requirements for manuscripts submitted to biomedical journals. [2011 Jul 15]. Available from:

http://www.nlm.nih.gov/bsd/uniform_requirements.html. 
Bodily J, Laimins LA. Persistence of human papillomavirus infection: Keys to malignant progression. Trends Microbiol. 2011;19;33-9.

Borbely AA, Murvai M, Konya J, Beck Z, Gergely L, Li F, Veress G. Effects of human papillomavirus type 16 oncoproteins on survivin gene expression. J Gen Virol. 2006;87:287-94.

Borges-OsóRio MR, Robinson WM. Genética Humana. 2. ed. Porto Alegre: Artmed, p.278-99, 2001.

Bosch FX, Munoz N. The viral etiology of cervical cancer. Virus Res. 2002;89(2):18390.

Boshart M, Boshart M, Gissmann L, Ikenberg H, Kleinheinz A, Scheurlen W, zur Hausen $\mathrm{H}$. A new type of papillomavirus DNA, its presence in genital cancer biopsies and in cell lines derived from cervical cancer. EMBO J. 1984;3(5):1151-7.

Boutros M, Kiger AA, Armknecht S, Kerr K, Hild M, Koch B, Haas SA, Paro R, Perrimon N. Genome-wide RNAi analysis of growth and viability in Drosophila cells. Science. 2004;303;832-5.

Bravo IG, De Sanjosé S, Gottschling M. The clinical importance of un- derstanding the evolution of papillomaviruses. Trends in Microbiology. 2010;18(10):432-8.

Bridges CB. The origin of variation. Amer Nat. 1922;56:51-63.

Brown C, Kowalczyk AM, Taylor ER, Morgan IM, Gaston K. P53 represses human papillomavirus type 16 DNA replication via the viral E2 protein. Virol. J. 2008;5:5.

Brunetti A, Manfioletti G, Chiefari E, Goldfine ID, Foti D. Transcriptional regulation of human insulin receptor gene by the high-mobility group protein $\mathrm{HMGl}(\mathrm{Y})$. FASEB J. 2001;15:492-500.

Bruni L, Diaz M, Castellsagué X, Ferrer E, Bosch FX, De Sanjosé S. Cervical human papillomavirus prevalence in 5 continents: meta-analysis of 1 million women with normal cytological findings. J Infect Dis. 2010;202(12):1789-99.

Bussemakers MJ, Van de Ven WJ, Debruyne FM, Schalken JA. Identification of high mobility group protein $\mathrm{I}(\mathrm{Y})$ as potential progression marker for prostate cancer by differential hybridization analysis. Cancer Res. 2015;51:606-11.

Campo MS: Papillomavirus and disease in humans and animals. Vet Comp Oncol. 2003;1:3-14.

Chan PK, Luck AC, Luk TN, Lee KF, Cheung JL, Ho KM et al. Distribu- tion of human papilomavírus types in anogenital warts of men. J Clin Virology. 2009;44(2):111-4. 
Chellappan S, Kraus VB, Kroger B, Munger K, Howley PM, Phelps WC, Nevins JR. Adenovirus $\mathrm{E} 1 \mathrm{~A}$, simian virus 40 tumor antigen, and human papillomavirus $\mathrm{E} 7$ protein share the capacity to disrupt the interaction between transcription factor E2F and the retinoblastoma gene product. Proc Natl Acad Sci USA. 1992;89:4549-53.

Chen HC, Schiffman M, Lin CY, Pan MH, You SL, Chuang LC, Hsieh CY, Liaw KL, Hsing AW, Chen CJ. Persistence of type-specific human papillomavirus infection and increased long-term risk of cervical cancer. J Natl Cancer Inst. 2011;103;1387-96.

Chen J. "Ataxia telangiectasia-related protein is involved in the phosphorylation of BRCA1 following deoxyribonucleic acid damage". Cancer Res. 2000;60(18):5037-9.

Chen JJ. Genomic instability induced by human papillomavirus oncogenes. The North American Journal of Medicine and Science. 2010;2:43-47.

Clifford GM, Smith JS, Plummer M, Muñoz NFS. Human papillomavirus types in invasive cervical cancer worldwide : a meta-analysis. Br J Cancer. 2003;88:63-73;

Constantin N, Dzantiev L, Kadyrov FA, Modrich P. Human mismatch repair: reconstitution of a nick-directed bidirectional reaction. $J$ Biol Chem. 2005;2;280(48):39752-61.

Davalos AR, Kawahara M, Malhotra GK, Schaum N, Huang J, Ved U, Beausejour CM, Coppe JP, Rodier F, Campisi J. Davalos et al. p53-dependent release of Alarmin HMGB1 is a central mediator of senescent phenotypes. JCB. 2013;613-29.

De Sanjosé S, Diaz M, Castellsagué X, Clifford G, Bruni L, Muñoz N et al. Worldwide prevalence and genotype distribution of cervical human papillomavirus DNA in women with normal cytology: a meta-analysis. Lancet Infect Dis. 2007;7:453-9.

De Sanjosé S, Quint WGV, Alemany L, Geraets DT, Klaustermeier JE, Lloveras B et al. Human papillomavirus genotype attribution in invasive cervical cancer: a retrospective cross-sectional worldwide study. Lancet Oncol. 2010;11:1048-56.

Demers GW, Foster SA, Halbert CL, Galloway DA: Growth arrest by induction of p53 in DNA damaged keratinocytes is bypassed by human papillomavirus 16 E7. Proc Natl Acad Sci USA. 1994;91:4382-86.

Dobzhansky T. Genetics of natural populations. XIII. Recombination and variability in populations of Drosophila pseudoobscura. Genetics. 1956;31:269-90.

Dolde CE, Mukherjee M, Cho C, Resar LM. HMG-I/Y in human breast cancer cell lines. Breast Cancer Res Treat. 2002;71:181-91.

Doorbar J. The papillomaviruses life cycle. J Clin Virol. 2005;32:S7-15. 
Duensing S, Lee LY, Duensing A, Basile J, Piboonniyom S, Gonzalez S, Crum CP and Munger $\mathrm{K}$. The human papillomavirus type 16 E6 and E7 oncoproteins cooperate to induce mitotic defects and genomic instability by uncoupling centrosome duplication from the cell division cycle. Proc Natl Acad Sci USA. 2000;97:10002-7.

Duensing S, Munger K. Human papillomaviruses and centrosome duplication errors: modeling the origins of genomic instability. Oncogene. 2002;21:6241-8.

Durst M, Gissmann L, Ikenberg H, Zur Hausen H. A papillomavirus DNA from a cervical carcinoma and its prevalence in cancer biopsy samples from different geographic regions. Proc Natl Acad Sci USA. 1983;80:3812-5.

Dzantiev L, Constantin N, Genschel J, lyer RR, Burgers PM, Modrich P. A defined human system that supports bidirectional mismatch-provoked excision. Mol Cell. 2004;15:31-41.

Eastman A., "Activation of programmed cell death by anticancer agents: cisplatin as a model system," Cancer Cells. 1990;2;275-80.

el-Deiry WS, Harper JW, O'Connor PM, Velculescu VE, Canman CE, Jackman J, Pietenpol JA, Burrell M, Hill DE, Wang $Y$ and et al.. WAF1/CIP1 is induced in p53mediated G1 arrest and apoptosis. Cancer Res. 1994;54:1169- 74.

el-Deiry, WS; Tokino, T; Velculescu, VE; Levy, DB; Parsons, R; Trent, JM; Lin, D; Mercer, WE; Kinzler, KW and Vogelstein, B.. WAF1, a potential mediator of p53 tumor suppression. Cell. 1993;75:817-25.

Elbashir SM, Lendeckel W, Tuschl T. RNA interference is mediated by 21- and 22nucleotide RNAs. Genes Dev. 2001;15:188-200.

Elbashir, S.M., et al., Duplexes of 21-nucleotide RNAs mediate RNA interference in cultured mammalian cells. Nature. 2001;411, 494-498.

Eskander RN, Tewari KS.. PARP inhibition and synthetic lethality in ovarian cancer. Expert Rev Clin Pharmacol. 2014;2:1-10.

Fang WH, Modrich P. Human strand-specific mismatch repair occurs by a bidirectional mechanism similar to that of the bacterial reaction. J Biol Chem. 1993;5;268:11838-44.

Fashena SJ, Reeves R, Ruddle NH. A poly(dA-dT) upstream activating sequence binds high-mobility group I protein and contributes to lymphotoxin (tumor necrosis factor-beta) gene regulation. Mol Cell Biol. 1992;12:894-903.

Fedele M, Bandiera A, Chiappetta G, Battista S, Viglietto G, Manfioletti G, Casamassimi A, Santoro M, Giancotti V, Fusco A. Human colorectal carcinomas express high levels of high mobility group $\mathrm{HMGl}(\mathrm{Y})$ proteins. Cancer Res. 1996;56:1896-901. 
Fire A, Xu S, Montgomery MK, Kostas SA, Driver SE, Mello CC. Potent and specific genetic interference by double-stranded RNA in Caenorhabditis elegans. Nature. 1998;391:806-11.

Flores E.R., Allen-Hoffmann B.L., Lee D., Lambert P.F. The human papillomavirus type $16 \mathrm{E} 7$ oncogene is required for the productive stage of the viral life cycle. J Virol. 2000;74:6622-31.

Flores ER, Lambert PF. Evidence for a switch in the mode of human papillomavirus type 16 DNA replication during the viral life cycle. J Virol. 1997;71:7167-79.

Fong PC. Inhibition of poly(ADP-ribose) polymerase in tumors from BRCA mutation carriers. N Engl J Med. 2009;361:123-34.

Fong PC. Poly(ADP)-ribose polymerase inhibition: frequent durable responses in BRCA carrier ovarian cancer correlating with platinum-free interval. J Clin Oncol. 2010;28:2512-19.

Fradet-Turcotte A, Bergeron-Labrecque F, Moody CA, Lehoux M, Laimins LA, Archambault J. Nuclear accumulation of the papillomavirus E1 helicase blocks Sphase progression and triggers an ATM-dependent DNA damage response. J Virol. 2011;85:8996-9012.

Friedberg E. DNA Repair and Mutagenesis, 2nd Edition. Washington D.C. ASM Press. 2006.

Gatei M, Scott SP, Filippovitch I, Soronika N, Lavin MF, Weber B et al.. Role for ATM in DNA damage-induced phosphorylation of BRCA1. Cancer Res. 2000;60:3299304.

Gatei, M., Zhou, B. B., Hobson, K., Scott, S., Young, D., and Khanna, K. K.. Ataxia telangiectasia mutated (ATM) kinase and ATM and Rad3 related kinase mediate phosphorylation of BRCA1 at distinct and overlapping sites. In vivo assessment using phospho-specific antibodies. J Biol Chem. 2001;276:17276-80.

Genois MM, Paquet ER, Laffitte MC, Maity R, Rodrigue A, Ouellette M, Masson JY. DNA repair pathways in trypanosomatids: from DNA repair to drug resistance. Microbiol Mol Biol Rev. 2014;78:40-73.

Gewin L, and Galloway DA,E box-dependent activation of telomerase by human papillomavirus type 16 E6 does not require induction of c-myc. J Virol. 2001;75:7198201.

Giampieri S, Storey A. Repair of UV-induced thymine dimers is compromised in cells expressing the E6 protein from human papillomaviruses types 5 and 18 . Br J Cancer. 2004;90:2203-9.

Giannoudis A, Evans MF, Southern SA, Herrington C. Basal keratinocyte tetrasomy in low-grade squamous intra-epithelial lesions of the cervix is restricted to high and intermediate risk HPV infection but is not typespecific. Br J Cancer. 2000;82:424-8. 
Gillespie KA, Mehta KP, Laimins LA, Moody CA. Human papillomaviruses recruit cellular DNA repair and homologous recombination factors to viral replication centers. J Virol. 2012;86:9520-6.

GM, Lee J-H, Stockwell H, Rollison DE, Wu Y, Papenfuss MR et al. Incidence and Human Papillomavirus (HPV) type distribution of genital warts in a multinational cohort of men: the HPV in men study. J Infect Dis. 2011;204:1886-92. Software.

GraphPad Software. Version 6.0. San Diego:CA,USA. GraphPad Prism Inc. Hannon, G.J., RNA Interference. Nature. 2002;418:244-51.

Hao Q, Du XQ, Fu X, Tian J. Expression and clinical significance of HMGB1 and RAGE in cervical squamous cell carcinoma. Zhonghua Zhong Liu Za Zhi. 2008;30:292-295.

Hashida T, Yasumoto S. Induction of chromosome abnormalities in mouse and human epidermal keratinocytes by the human papillomavirus type 16 E7 oncogene. J Gen Virol. 1991;72:1569-77.

Heilman SA, Nordberg JJ, Liu Y, Sluder G, Chen JJ. Abrogation of the postmitotic checkpoint contributes to polyploidization in human papillomavirus E7-expressing cells. J Virol. 2009;83:2756-64.

Hekmat-Nejad M, You Z, Yee Met al. Xenopus ATR is a replication-dependent chromatin-binding protein required for the DNA replication checkpoint. Curr Biol. 2000;10:1565-73.

Hoeijmakers JHJ. Genome maintenance mechanisms for preventing cancer. Nature. 2001;411:366-74.

Hong S, Laimins LA. The JAK-STAT Transcriptional Regulator, STAT-5, Activates the ATM DNA Damage Pathway to Induce HPV 31 Genome Amplification upon Epithelial Differentiation. PLoS Pathogens. 2013;9.

Howley PM, Lowy DR. Papillomaviruses. In: Knipe DM, Howley PM. Fields Virology. 5th. Philadelphia. Lippincot Williams e Wilkins, 2007.

IARC Working Group. Human papillomaviruses. IARC Monographs on the evaluation of carcinogenic risk to humans. International Agency for Research on Cancer. Lyon: IARC; 2007;90.

Iftner T, Elbel M, Schopp B, Hiller T, Loizou JI, Caldecott KW, et al. Interference of papillomavirus E6 protein with single-strand break repair by interaction with XRCC1. Embo J. 2002;21:4741-8. 
Instituto Nacional de Câncer (INCA). Câncer do colo do útero. [Citado em 22 de setembro de 2016]. Disponível em: www2.inca.gov.br/wps/wcm/connect/tiposdecancer/site/home/colo_utero

Jackson S, Harwood C, Thomas M, Banks L, Storey A. Role of Bak in UV-induced apoptosis in skin cancer and abrogation by HPV E6 proteins. Genes Dev. 2000;14:3065-73.

James MA, Lee JH, Klingelhutz AJ. Human papillomavirus type 16 E6 activates NFkappaB, induces clAP-2 expression, and protects against apoptosis in a PDZ binding motif-dependent manner. J Virol. 2006;80:5301-7.

Jayaraman LNC, Moorthy KG, Murthy JL, Manley M, Bustin C. Prives. High mobility group protein-1 (HMG-1) is a unique activator of p53. Genes Dev. 1998;12:462-72.

Kadaja M, Isok Paas H, Laos T, Ustav E, Ustav M. Mechanism of Genomic Instability in Cells Infected with the High-Risk Human Papillomaviruses. PLoS Pathog. 2009;5.

Kang R, Chen R, Zhang Q, Hou W, Wu S, Cao L, Huang J, Yu Y, Fan XG, Yan Z, Sun X, Wang H, Wang Q, Tsung A, Billiar TR, Zeh HJ 3rd, Lotze MT, Tang D. HMGB1 in health and disease. Mol Aspects Med. 2014;40:1-116.

Kastan MB, Bartc J. Cell cycle checkpoints and cancer. Nature. 2004;432:316-23.

Kessis TD, Slebos RJ, Nelson WG, Kastan MB, Plunkett BS, Han SM, Lorincz AT, Hedrick L, Cho KR. Human papillomavirus 16 E6 expression disrupts the p53mediated cellular response to DNA damage. Proc Natl Acad Sci USA. 1993;90:398892.

Kessis TD1, Connolly DC, Hedrick L, Cho KR. Expression of HPV16 E6 or E7 increases integration of foreign DNA. Oncogene. 1996;18;13:427-31.

Kho EY, Wang HK, Banerjee NS, Broker TR, Chow LT. HPV-18 E6 mutants reveal p53 modulation of viral DNA amplification in organotypic cultures. Proc. Natl. Acad. Sci. USA. 2013;110:7542-9.

Kisseljov FL. Virus-associated human tumors: cervical carcinomas and papilloma viruses. Biochemistry. 2000;65:68-77. Tradução de Biokhimiya. 2000;65:79-91.

Klingelhutz AJ, Foster SA, McDougall JK. Telomerase activation by the E6 gene product of human papillomavirus type 16. Nature. 1996;7:380;79-82.

Klune JR, Dhupar R, Cardinal J, Billiar TR, Tsung A. HMGB1: endogenous danger signaling. Mol Med. 2008;14:476-84.

Kuniyasu $\mathrm{H}$, Chihara $\mathrm{Y}$, Kondo $\mathrm{H}$, Ohmori $\mathrm{H}$, Ukai $\mathrm{R}$. Amphoterin induction in prostatic stromal cells by androgen deprivation is associated with metastatic prostate cancer. Oncol Rep. 2003;10:1863-8. 
Lanuszewska J, Widlak P. High mobility group 1 and 2 proteins bind preferentially to DNA that contains bulky adducts induced by benzopyrene diol epoxide and $\mathrm{N}$ acetoxy-acetylaminofluorene. Cancer Lett. 2000;29;158:17-25.

Lazarczyk M, Cassonnet P, Pons C, Jacob Y, Favre M. The EVER proteins as a natural barrier against papillomaviruses: a new insight into the pathogenesis of human papillomavirus infections. Microbiology and Molecular Biology Reviews. 2009;73:348-70.

Lebedev TD, Spirin PV, Prassolov VS. Transfer and Expression of Small Interfering RNAs in Mammalian Cells Using Lentiviral Vectors. Acta naturae. 2013;5:7-18.

Lee JH, Paull TT. "Activation and regulation of ATM kinase activity in response to DNA double-strand breaks". Oncogene. 2007;26:7741-8.

Lee JS, Collins KM, Brown AL, Lee CH, Chung JH. hCds1-mediated phosphorylation of BRCA1 regulates the DNA damage response. Nature. 2000;404:201-4.

Leman Es, Madigan MC, Brünagel G, Takaha N, Coffey DS, Getzenberg RH. Nuclear matrix localization of high mobility group protein $\mathrm{I}(\mathrm{Y})$ in a transgenic mouse model for prostate cancer. J Cell Biochem. 2003;88:599-608.

Lembo D, Donalisio M, Cornaglia M, Azzimonti B, Demurtas A, Landolfo S: Effect of highrisk human papillomavirus oncoproteins on p53R2 gene expression after DNA damage. Virus Res. 2006;122:189-93.

Li N, Franceschi S, Howell-Jones R, Snijders PJF, Clifford GM. Human Papillomavirus type distribution in 30,848 invasive cervical cancers worl- dwide: variation by geographical region, histological type and year of publication. Int $\mathrm{J}$ Cancer. 2011;128:927-35.

Lieber, M.R. et al. Mechanism and regulation of human non-homologous DNA endjoining. Nature reviews. Molecular cell biology, 2003;4:712-20.

Lindahl T. Instability and decay of the primary structure of DNA. Nature. 1993;362:709-15.

Liu X, Han S, Baluda MA, Park N. HPV-16 oncogenes E6 and E7 are mutagenic in normal human oral keratinocytes. Oncogene. 1997;14:2347-53.

Liu Y, Heilman SA, Illanes D, Sluder G, Chen JJ. p53-independent abrogation of a postmitotic checkpoint contributes to human papillomavirus E6-induced polyploidy. Cancer Res. 2007;67:2603-10.

Lowndes NF, Murguia, JR. Sensing and responding to DNA damage. Curr Opin Genet Dev. 2000;10:17-25.

Madison KC. Barrier function of the skin: "la raison d'etre" of the epidermis. J Invest Dermatol. 2003;121:231-41. 
Marchetti B, Ashrafi GH, Tsirimonaki E, O'Brien PM, Campo MS. The bovine papillomavirus oncoprotein E5 retains MHC class I molecules in the Golgi apparatus and prevents their transport to the cell surface. Oncogene. 2002;21:7808-16.

Markowitz D, Goff S, Bank A. Construction of a safe and efficient retrovirus packaging cell line. Virology. 1988;67:400-6.

Marteijn JA, Lans H, Vermeulen W, Hoeijmakers JH. Understanding nucleotide excision repair and its roles in cancer and ageing. Nat Rev Mol Cell Biol. 2014;15:465-81.

Martinez J, Patkaniowska A, Urlaub $\mathrm{H}$, Luhrmann R, Tuschl T. Single-stranded antisense siRNAs guide target RNA cleavage in RNAi. Cell. 2002;110:563-74.

Matthews K, Leong CM, Baxter L, Inglis E, Yun K, Backstrom BT, et al. Depletion of Langerhans cells in human papillomavirus type 16-infected skin is associated with E6-mediated down regulation of E-cadherin. J Virol. 2003;77:8378-85.

McMurray HR, Nguyen D, Westbrook TF, Mc Ance DJ. Biology of human papillomavirus. Int J Exp Path. 2001;82:15-33.

Méhes G, Speich N, Bollmann M, Bollmann R: Chromosomal aberrations accumulate in polyploid cells of high-grade squamous intraepithelial lesions (HSIL). Pathol Oncol Res. 2004;10:142-8.

Meisels A, Fortin R. Condylomatous lesions of the cervix and vagina. I. Cytologic patterns. Acta Cytologica. 1976;20:505-9.

Melchionna R, Chen XB, Blasina A et al. Threonine 68 is required for radiationinduced phosphorylation and activation of Cds1. Nat Cell Biol. 2:762-765, 2000.

Mendes-Pereira A.M. Synthetic lethal targeting of PTEN mutant cells with PARP inhibitors. EMBO Mol Med. 2009;1:315-22.

Micah A. Luftig. Viruses and the DNA Damage Response: Activation and Antagonism. Annual Review of Virology. 2014;1:605-25.

Modrich P. Mechanisms in eukaryotic mismatch repair. J Biol Chem. 2006;13;281:30305-9.

Mohammad, D.H. and Yaffe, M.B. 14-3-3 proteins, FHA domains and BRCT domains in the DNA damage response. DNA Repair (Amst.). 2009;8:1009-17.

Moody CA, Laimins LA. Human papillomaviruses activate the ATM DNA damage pathway for viral genome amplification upon differentiation. PLoS Pathog. 2009;5.

Morale, MG. Efeito da infecção por HPV nas vias de sinalização por Toll Like Receptors. 121 p. Tese de Doutorado. Universidade de São Paulo, Instituto de Química. São Paulo, 2016. 
Münger K, Phelps WC, Bubb V, Howley PM, Schlegel RJ. The E6 and E7 genes of the human papillomavirus type 16 together are necessary and sufficient for transformation of primary human keratinocytes. J Virol. 1989;63:4417-21.

Muñoz N, Bosch FX, De Sanjosé S, Herrero R, Castellsagué X, Shah KV et al. Epidemiologic Classification of Human Papillomavirus types asso- ciated with cervical cancer. N Engl J Med. 2003;348:518-27.

Nakamura J, Mutlu E, Sharma V, Collins L, Bodnar W, Yu R, Lai Y, Moeller B, Lu K, Swenberg J. The endogenous exposome. DNA Repair. 2014;19:3-13.

Narisawa-Saito M, Kiyono T. Basic mechanisms of high-risk human papillomavirusinduced carcinogenesis: roles of E6 and E7 proteins. Cancer Sci. 2007;98:1505-11.

Narod SA, Foulkes WD. BRCA1 and BRCA2: 1994 and beyond. Nat Rev Cancer. 2004;4:665-76.

Neshat MS, Mellinghoff IK, Tran C, Stiles B, Thomas G, Petersen R, Frost P, Gibbons JJ, Wu H, Sawyers CL. Enhanced sensitivity of PTEN-deficient tumors to inhibition of FRAP/mTOR. Proc Natl Acad Sci USA. 2001;98:10314-9.

Nestl A, Von Stein OD, Zatloukal K, Thies WG, Herrlich P, Hofmann M, Sleeman JP.. Gene expression patterns associated with the metastatic phenotype in rodent and human tumors. Cancer Res. 2001;61:1569-77.

Nguyen CL, Eichwald C, Nibert ML, Munger K. Human papillomavirus type 16 E7 oncoprotein associates with the centrosomal component gamma-tubulin. J Virol. 2007;81:13533-43.

Nguyen CL, McLaughlin-Drubin ME, Munger K. Delocalization of the microtubule motor Dynein from mitotic spindles by the human papillomavirus E7 oncoprotein is not sufficient for induction of multipolar mitoses. Cancer Res. 2008;68:8715-22.

Nicola J. Curtina, Csaba Szabo. Therapeutic applications of inhibitors: Anticancer therapy and beyond. Mol Aspects Med. 2013;34:1217-56.

Nijman, S.M. Synthetic lethality: general principles, utility and detection using genetic screens in human cells. FEBS Lett. 2011;585:1-6.

Ohndorf UM1, Rould MA, He Q, Pabo CO, Lippard SJ. Basis for recognition of cisplatin-modified DNA by highmobility-group proteins. Nature. 1999;17;399:708-12.

Pandita TK, Lieberman HB, Lim DS et al. Ionizing radiation activates the ATM kinase throughout the cell cycle. Oncogene 2000;19:1386-91.

Pang X, Zhang Y, Wei H, Zhang J, Luo Q, Huang C, Zhang S. Expression and effects of high-mobility group box 1 in cervical cancer. Int $J$ Mol Sci. 2014;15;15:8699-712. 
Park R.B., Androphy E.J. Genetic analysis of high-risk e6 in episomal maintenance of human papillomavirus genomes in primary human keratinocytes. $J$ Virol. 2002;76:11359-64.

Pasheva EA, Pashev IG, Favre A. Preferential binding of high mobility group 1 protein to UV-damaged DNA. Role of the $\mathrm{COOH}$-terminal domain. J Biol Chem. 1998;18;273:24730-6.

Pei XF, Sherman L, Sun YH, Schlegel R. HPV-16 E7 protein bypasses keratinocyte growth inhibition by serum and calcium. Carcinogenesis. 1998;19:1481-86.

Podsypanina K, Lee RT, Politis C, Hennessy I, Crane A, Puc J, Neshat M, Wang H, Yang L, Gibbons J, Frost P, Dreisbach V, Blenis J, Gaciong Z, Fisher P, Sawyers C, Hedrick-Ellenson L, Parsons R. An inhibitor of mTOR reduces neoplasia and normalizes p70/S6 kinase activity in Pten+/- mice. Proc Natl Acad Sci USA. 2001;98:10320-5.

Ram TG, Reeves R, Hosick HL. Elevated high mobility group-I(Y) gene expression is associated with progressive transformation of mouse mammary epithelial cells. Cancer Res. 1993;53:2655-60.

Reinson T, Toots M, Kadaja M, Pipitch R, Allik M, Ustav E, Ustav M. Engagement of the ATR-dependent DNA damage response at the human papillomavirus 18 replication centers during the initial amplification. J Virol. 2013;87:951-64.

Rey O, Lee S, Park NH: Impaired nucleotide excision repair in UV-irradiated human oral keratinocytes immortalized with type 16 human papillomavirus genome. Oncogene. 1999;18:6997-7001.

Rogoff HA, Pickering MT, Frame FM, Debatis ME, Sanchez Y, Jones S, Kowalik TF. Apoptosis associated with deregulated E2F activity is dependent on E2F1 and Atm/Nbs1/Chk2. Mol Cell Biol. 2004;24:2968-77.

Rosen EM, Pishvaian MJ. Targeting the BRCA1/2 tumor suppressors. Curr Drug Targets. 2014;15:17-31.

Sabine SL, David LM, Karen MV. High mobility group protein B1 enhances DNA repair and chromatin modification after DNA damage. Proc Natl Acad Sci USA. 2008;105:10320-5.

Sakakibara N, Mitra R, McBride AA. The papillomavirus E1 helicase activates a cellular DNA damage response in viral replication foci. J Virol. 2011;85:8981-95.

Sancar A, Lindsey-Boltz LA, Unsal-Kaçmaz K, Linn S. Molecular mechanisms of mammalian DNA repair and the DNA damage checkpoints. Annu Rev Biochem. 2004;73:39-85.

Sancar A, Lindsey-Boltz LA, Unsal-Kaçmaz K, Linn S. Molecular mechanisms of mammalian DNA repair and the DNA damage checkpoints. Annu Rev Biochem. 2004;73:39-85. 
Sanclemente G, Gill DK. Human papillomavirus molecular biology and pathogenesis. J Eur Acad Dermatol Venereol. 2002;16: 231-40.

Scheffner M, Whitaker NJ. Human papillomavirus induced carcinogenesis and the ubiquitin-proteasome system. Semin Cancer Biol. 2003;13:59-67.

Scully C. Oral squamous cell carcinoma: from an hypothesis about a virus, to concern about possible sexual transmission. Oral Oncol. 2002;38:227-34.

Sherman L, Jackman A, Itzhaki H, Stoppler MC, Koval D, Schlegel R. Inhibition of serum- and calcium-induced differentiation of human keratinocytes by HPV16 E6 oncoprotein: role of p53 inactivation. Virology. 1997;237:296-306.

Sherman SED, Gibson D, Wang AHJ, Lippard SJ. "X-ray structure of the major adduct of the anticancer drug cisplatin with DNA: cis-[Pt(NH3)2\{d(pGpG)\}]," Science. $1985 ; 230 ; 4724: 412-17$.

Shin KH, Ahn JH, Kang MK, Lim PK, Yip FK, Baluda MA, Park NH. HPV-16 E6 oncoprotein impairs the fidelity of DNA end-joining via p53-dependent and independent pathways. Int J Oncol. 2006;28:209-215.

Sigma-Aldrich. Consultado em 14 de outubro de 2016. Disponível em: http://www.sigmaaldrich.com/technical-documents/articles/life-scienceinnovations/mission-shrna-library0.html\#R

Souto R, Falhari JPB, Cruz AD. O Papilomavírus Humano: um fator relacionado com a formação de neoplasias. Rev. Brasileira de Cancerologia. 2005;51;2:155-160.

Spardy N, Covella K, Cha E, Hoskins EE, Wells SI, Duensing A, Duensing S. Human papillomavirus 16 E7 oncoprotein attenuates DNA damage checkpoint control by increasing the proteolytic turnover of claspin. Cancer Res. 2009;69:7022-9.

Srivenugopal KS, Ali Osman F. The DNA repair protein, $\mathrm{O}(6)$-methylguanine-DNA methyltransferase is a proteolytic target for the E6 human papillomavirus oncoprotein. Oncogene. 2002;21:5940-5.

Stubenrauch F, Laimins LA. Human Papillomavirus life cycle: active and latent phases. Cancer Biol. 1999;9:379-86.

Sulli G, Micco RD, Fagagna FA. Crosstalk between chromatin state and DNA damage response in cellular senescence and cancer. 2012. Nat Rev Cancer. 2012;12:709-20.

Synowiec A, Wcisło G, Bodnar L, Gasowska-Bodnar A, Szczylik C.. Screening for ovarian cancer in BRCA1/BRCA2 mutations carriers. Ginekol Pol. 2014;85:377-81.

Takaha N, Hawkins AL, Griffin CA, Isaacs WB, Coffey DS. High mobility group protein $\mathrm{I}(\mathrm{Y})$ : a candidate architectural protein for chromosomal rearrangements in prostate cancer cells. Cancer Res. 2002;62:647-51. 
Tarbe N, Evtimova V, Burtscher H, Jarsch M, Alves F, Weidle UH. Transcriptional profiling of cell lines derived from an orthotopic pancreatic tumor model reveals metastasis-associated genes. AntiCancer Res. 2001;21:3221-8.

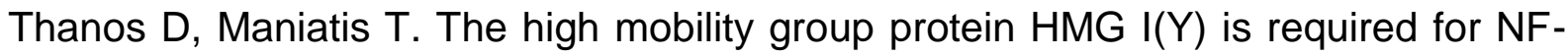
kappa B-dependent virus induction of the human IFN-beta gene. Cell. 1992;71:77789.

Therrien JP, Drouin R, Baril C, Drobetsky EA. Human cells compromised for p53 function exhibit defective global and transcriptioncoupled nucleotide excision repair, whereas cells compromised for $\mathrm{pRb}$ function are defective only in global repair. Proc Natl Acad Sci USA. 1999;96:15038-43.

Thomas JT, Hubert WG, Ruesch MN, Laimins LA. Human papillomavirus type 31 oncoproteins E6 and E7 are required for the maintenance of episomes during the viral life cycle in normal human keratinocytes. Proc Natl Acad Sci USA. 1999;96:8449-54.

Thomas M, Banks L. Human papillomavirus (HPV) E6 interactions with Bak are conserved amongst E6 proteins from high and low risk HPV types. J Gen Virol. 1999;80:1513-17.

Thomas M, Banks L. Inhibition of Bak-induced apoptosis by HPV-18 E6. Oncogene. 17:2943-54, 1998.

Tomari Y, Zamore PD. Genes Dev. 2005;19;5:517-29.

Tomlins C, Storey A. Cutaneous HPV5 E6 causes increased expression of Osteoprotegerin and Interleukin 6 which contribute to evasion of UV-induced apoptosis. Carcinogenesis. 2010;31:2155-64.

Underbrink MP, Howie HL, Bedard KM, Koop JI, Galloway DA. E6 proteins from multiple human betapapillomavirus types degrade Bak and protect keratinocytes from apoptosis after UVB irradiation. J Virol. 2008;82:10408-10417.

Villa LL. Aspectos moleculares da oncogênese por papilomavirus. In: Bibbo M, Silva Filho AM. Lesões relacionadas à infecção por HPV no trato anogenital. Rio de Janeiro: Revinter. 1998;51-8.

Wallace NA, Galloway DA. Manipulation of Cellular DNA Damage Repair Machinery Facilitates Propagation of Human Papillomaviruses. Seminars in Cancer Biology. 2014;26:30-42.

Wallace NA, Robinson K, Howie HL, Galloway DA. HPV 5 and 8 E6 Abrogate ATR Activity Resulting in Increased Persistence of UVB Induced DNA Damage. PLoS Pathog. 2012;8:e1002807. 
Wistuba II, Montellano FD, Milchgrub S, Virmani AK, Behrens C, Chen $\mathrm{H}$, Ahmadian M, Nowak JA, Muller C, Minna JD, Gazdar AF. Deletions of chromosome 3p are frequent and early events in the pathogenesis of uterine cervical carcinoma. Cancer Res. 1997;57:3154-8.

Woodman, C.B.; Collins, S.I.; Young, L.S. The natural history of cervical HPV infection: Unresolved issues. Nat. Rev. Cancer. 2007;7:11-22.

Wright JA, Keegan KS, Herendeen DR, Bentley NJ, Carr AM, Hoekstra MF, et al. Protein kinase mutants of human ATR increase sensitivity to UV and ionizing radiation and abrogate cell cycle checkpoint control. Proc Natl Acad Sci USA. 1998;95: 7445-50.

Wu W. The BRCA1 ubiquitin ligase and homologous recombination repair. FEBS Lett. 2011;585:2836-44.

Yi R, Qin Y, Macara IG, Cullen BR. Genes Dev. 2003;17;24:3011-16.

Yim EK, Lee KH, Myeong J, Tong SY, Um SJ, Park JS. Novel interaction between HPV E6 and BARD1 (BRCA1-associated ring domain 1) and its biologic roles. DNA and Cell Biology. 2007;26:753-61.

Yuan H, Fu F, Zhuo J, Wang W, Nishitani J, An DS, et al. Human papillomavirus type 16 E6 and E7 oncoproteins upregulate c-IAP2 gene expression and confer resistance to apoptosis. Oncogene. 2005;24:5069-78.

Zhang Y, Fan S, Meng Q, Ma Y, Katiyar P, Schlegel R, et al. BRCA1 interaction with human papillomavirus oncoproteins. J Biol Chem. 2005;280:33165-77.

Zhou, B.S. e Elledge, S.J.. Checkpoints in perspective. Nature. 2003;408:433-9.

Zur Hausen H. Papillomaviruses and cancer: From basic studies to clinical application. Nat Rev Cancer. 2002;2:342-50.

Zur Hausen $\mathrm{H}$. Papillomaviruses causing cancer: evasion from host-cell control in early events in carcinogenesis. J Natl Cancer Inst. 2000;92:690-8. 